\title{
A STUDY OF VARIOUS MEASUREMENT BASES AND THEIR EFFECT ON PERIODIC INCOME DETERMINATION
}

\author{
By \\ HOWARD PRESTON SANDERS
}

A DISSERTATION PRESENTED TO THE GRADUATE COUNCIL OF THE UNIVERSITY OF FLORIDA

IN PARTIAL FULFLLMENT OF THE REQUIREMENTS FOR THE DEGREE OF DOCTOR OF PHILOSOPHY

UNIVERSITY OF FLORIDA

August, 1967 


\section{ACaiv UWLDD.ALAT'}

The author wishos to express his approciation to Dr. W. B. Stone, unciur whose suporvision this investigation was compioted. Appreciation is also expressed to Dr. R. H. Biudigutt, Dr. C. W. Eristue, Or. W. M. Howard, and Dr. D. D. Fay wiro sorval on tho author's committeo and to Dr. L. J. Eenuinger and Wr. R. Wixou who each served temporarily as chairuan while the investigation was underway.

The author wishes to express his gratitude to his wife, Shirley, who spent many hours typing the manuscript, proofreading, giving Eoneral assistance, and most of all--glving constant moral support. 
TABL ¿̈ OF CUNTENTS

Page

ACKNOWLEDGMENTS $\ldots \ldots \ldots \ldots \ldots \ldots \ldots \ldots \ldots \ldots \ldots \ldots \ldots \ldots$

Chapter

I. intruduction $\ldots \ldots \ldots \ldots \ldots \ldots \ldots \ldots \ldots \ldots \ldots \ldots \ldots \ldots$

Internal Use of Accounting Statements . 2

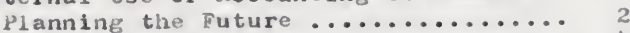

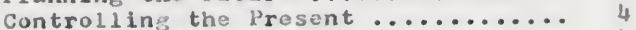

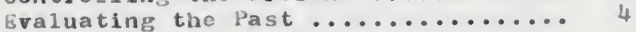
Stewardship ..................... 5 isternal Use of Accounting Statements. 6 Investors and prospective Investors . 7 Creditors and Prospective Creditors . 9 Social Cuntrol Agencies ........... Il

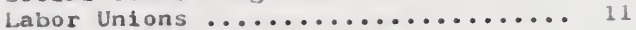
Comparison of Internal and ixternal

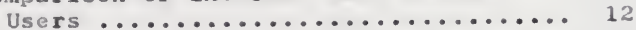

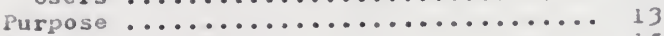

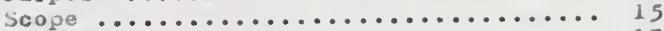

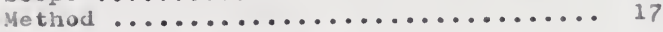

I. Méasurement in ACCuUntrini ............ 13

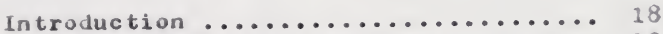

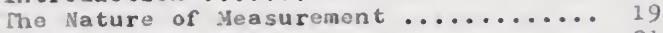

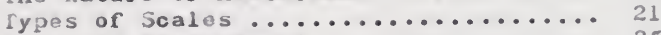

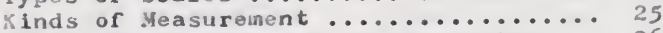

Impact of Measurement on Accounting ... 26 Definitions of Accountini ........ 26 Inportance of Measurement in Account-

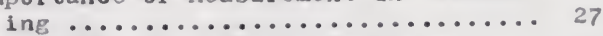

Basic Structure of the Business

Measurement Process ..................... 29

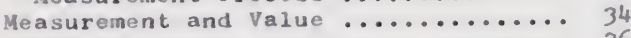

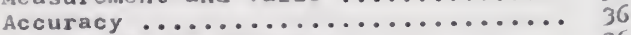

Accuracy in sciences .................. 36

Probability and Dogree of irror ... 37 Scales in Accounting ............. 33 Kinds of Heasurement in Accountin: .. 39 Criteria for Comparing Measuremont ... 40 Methods .................................. 41 
III. HISTORTCAL CUST ................. 42

Introduction $\ldots \ldots \ldots \ldots \ldots \ldots \ldots . \ldots \ldots$

Definition of IIStorical Cost ......... 43

Related Concopts Underlying Accounting

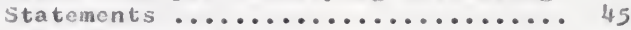

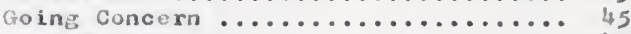

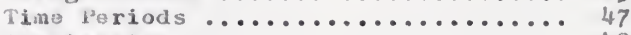

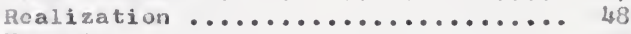

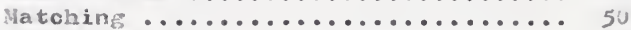

ubjectivity ...................... 51

Conservatism ................. 52

Sumnary ..................... 53

The Roalization Concept .............. 54

Historical Development of the Reali-

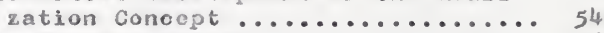

The iresent status ............... 56

Currently accepted exceptions to

the general rule for realization 62

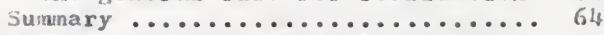

ifrects on Accounting statements and

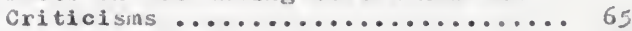

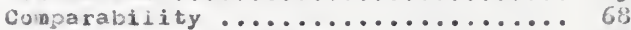

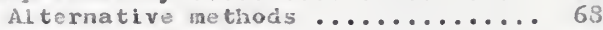

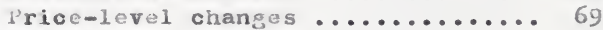

Uniformity .................. 71

Alternative methods ............ 71

Judgment .................... 72

rrico-1evel changes ............ 73

Mana zorant .................... 73

Investors and Prospective Investors. 74

Other krtornal Users ............ 83

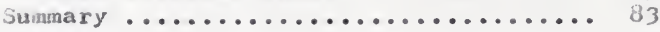

IV . CURRSNr cosr .................... 86

Introduction $\ldots \ldots \ldots \ldots \ldots \ldots \ldots \ldots$

Income ......................... 87

Price-level Adjustment Assunption ... 89

Variations of the Current Cost Concept 90

¿dwards and 3011 's Concept..........99 91

Sprouse and Hoonitz's Concept ...... 99

uther Current Cost Concepts ........... 107

The Most Dosirable of the Current

Cost Concopts .................110

Holding gains and losses ............11

squality of trains and lusses .... 112

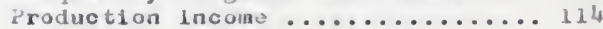


Comparison with the ilistorleal Cost

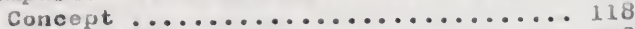

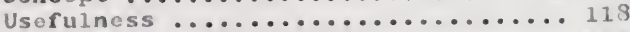

Accounting statements ............119

Inventory valuation .................... 121

other asset valuations ......... 122

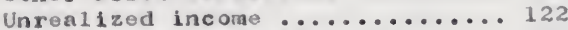

Dual accounting statements ..... 123

Implications for cost accounting .. 123

Inventory rlow assumption ...... 123

Absorption costinz vs. direct

costing controversy ......... 124

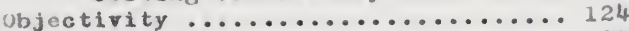

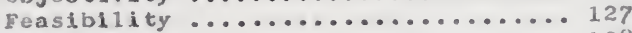

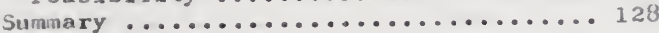

V. NET REALTIABLS VALUE .............. 130

Introduction ..................... 130

Rationale of Net Realizable Value ... 130

Variations of the Not Realigablo Value

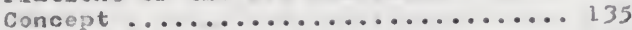

American Accounting Association ..... 135

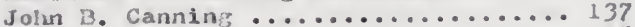

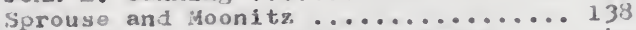

Actual Use of Net Realizable Value .... 142

Contrast with the Historical Cost Con-

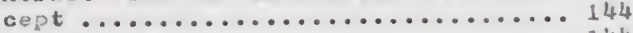

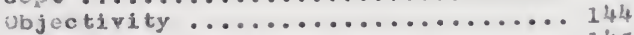

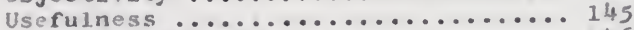

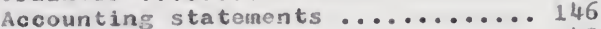

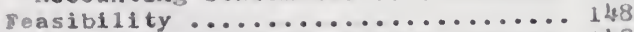

Contrast with the Current Cost Concept 148

lloldin; Gains and Losses .......... 149

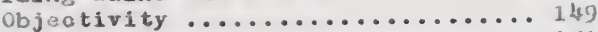

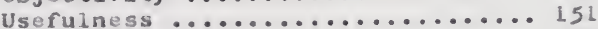

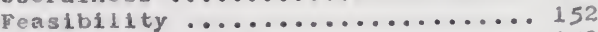

Production Income ............... 152

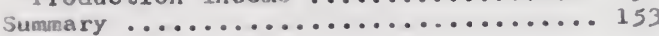

VI. UISCOUNTED CASH FLOW ............... 154

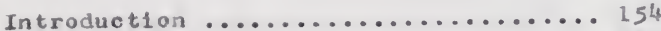

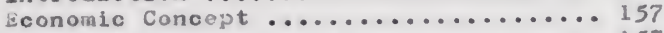

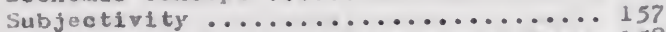

Comparison with other Measurement Bases 158

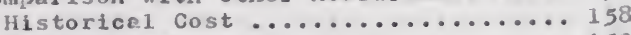

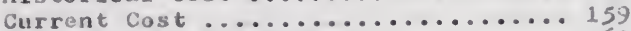

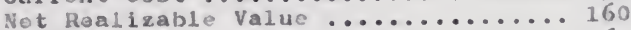

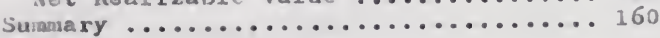

VII. SUMVARY AND CUNCLUSTURS ............. 162

HIBLIJURAPHY ......................... 182 


\section{LIST olf TA3!.35}

Table

Page

1. Tour Typos of Scales . . . . . . . . . 22

2. A Classirication of Scalos or Measurement . . 23

3. An Array of Value Concepts . . . . . . . 93

4. A Comparison of Roalization and Realizable Criteria... . . . . . . . . . 98 


\section{CILAPTER I}

\section{INTRODUCTI ON}

Accounting statements are the tangible product of the accounting process. The product is of no inportance within itself; the importance of accounting statements is in tho service they render to statement users. The rollowing paragraphs comprise a discussion of accounting statements largely in terms of those who read them and the purposes for which they read them.

The most familiar accounting statements are the balance sheet and the income statement. The number of types of statements for internal users is almost endless. With certain practical limits, management may prepare or have prepared any statement that may be userul to them. The external users have a more 1 imited supply of statements, being $11 \mathrm{mited} 1$ argely to what is known as the published financial statements. The pub11 shed financial statements are the roprosentations of management to outsiders. The published financial statements usually oonsist of tho balanco shoot, tho income statement, and the analysis of owners' equity (retained earnings, in the case of a corporation), but 
they may include other statements and details such as the source and application of runds statement.

The users of accounting statements can be divided, at least roughly, into two classes: internal users and external users. The internal users of accounting statements are all those who participato in tho management of the enterprise at any echelon. External users include investors (both present and prospeotive). creditors (both present and prospective), social control agencies (such as governmental units), labor unions, employees, consumers, and the general public.

\section{Internal Use of Accounting Statements}

The internal users of accounting statements are the various levels of management. Any given member of management is concerned primarily with accounting statements dealing with his area of responsibility and over which he has authority.

The chief runction of management is decision making. Managerial docisions may be divided into threo areas: planning, controlling, and ovaluating. Accounting statements are utilized in aiding management in recognizing the need for docisions and in puiding management in making the decisions in all throe aroas.

\section{Planning tho Future}

The three areas of concern to management may be thought of as a cyclo. A discussion of the three areas may begin with any one. The planning area has 
been chosen becauso this would be tho first area of interest to the manapemont of a nowly organizod or prospective ontity. After the onterprise is underway, plannin; is of continuous concern to manameinont.

jome writers express the view that accountin: deals only with past events. This concept of accountinis would exclude fron the realm of accountinis statements those dealing with the futuro, such as various types of budigets. Accounting as usad in this study is intended to include estimates of and prospects for the ruture as woll as records of the past.

After an entity is underway it is at once in the planninz area, the controlling area, and the evaluatin: area. The three areas may be thought of separately in the sense that a momber of manazoment may direct his attention toward only one area at a time. For example, manazement may rocus its attention on tho plannin; area as a new riscal year approaches.

rlans for the ruture are made after a careful evaluation of the past. tixperience in the past inay serve as a guido to the future. Trends may be indicated, for example. The accountinz statemonts for prior accountin; poriods are a major source of information in making rinancial plans for subsequent poriods. After an entity begins business, planning requires an evaluation of the past as well as a consideration of the ruture. 
Controlling the Prosent

Controlling the present implies the carrying out of plans made in the past. Controlling, as used here, includes the concepts of coordinating and motivating.

Manageinent follows the activities of an entity closely to see that there is compliance with the plans. Timely cost accounting reports which can be compared with the budgets are almost essential in this area. Management may decide to alter plans even after an accounting period has begun in order to control the enterprise activitios. Such changes may require speolal studies and rerised budgets. Interim acoounting statements such as the balance shoet, Income statement, and source and application of funds are useful. Such interim statements provide management with information concerning current status berore it is too late to make changes and corrections. It is probable that these interim statements would do nothing more than help point out a problem. Further analysis would be necessary to learn details.

\section{Livaluating the Past}

Evaluation is tiro prooess of determining what has been accomplished and the iaplioations of these past accomplishmonts. An effective way to dotermine what has beon accomplished is to compare results with 
the plan. the balance sheet, the incomo statement, and other accounting, statements are usod by marigement in evaluating the past.

Manajcment is ordinarily interested in much more detall than tho external statement users. Hxternal users look at the ontity as a whole, while managernent is interested in the constituent elemonts. For this reason, management may require detalled reports which explain varlous soctions of the peneral-purpose statements or answer speciflc quostions which ariso. isvaluation of the past is a prerequisito for and blends into the planning arva. ixcopt for the beginning and end of entity oporations, no area need be considered the first area or the last area. Planning the future, controliin; the present, and evaluatin: the past are sezments of an endless cycle of manazerial responsibility.

Stowardship

In a sense mamagoment uses the Beneral-purpose statements for external repurting in performing its stewardship acoountin.; responsibility to investors and creditors and in performin: its public-duty responsibility to the zeneral public. Thesc evaluations of the past are assumed to rulfill managenont's responsibility to uutsiders. "External reportin? has been traditionally oriented toward historical stewardship 
aspects, while internal reporting has been much aore concerned with current and future events" (1, p. 521).

\section{Gxternal Uso of Accountine Statements}

The external users compose a more heterogeneous group than the internal users. Most oxternal users have one thing in common with each other; their primary sources of information concerning the financial arfairs of an entity are the published rinancial statements. The term Inancial statements is less broad than the term accounting statements. Pinancial statements are defined by Sprouse and Moonitz as follows: "Flnanclal statements are those which purport to show rinancial position and results of operations, including supporting schedules, elaborations of special aspects of business activity, rearrangements of underlying data, and supplementary statements" (2, p. 8).

Some external users have sources of information In addition to the publishod financial statoments. Creditors and potontial creditors may require of management more detalled information such as plans concerning the future. Sootal agencies such as governmental units can and do roquire large quantities and various typos or data. Labor unions may sometinos acquire additional data. The investors and potential investors, as a group. have fow other sources of information. They must rely, directly or indirectly, on publishod rinancial statements. As individuals, they may have an 
Inside track, but this is not considored a significant exception.

An important purpose of accounting data is to ald external users in making decisions. As the typo of decisions to be made varies with the user, each typo or usor w111 be discussed separately.

Investors and Prospective Investors The general-purpose statements distributed to investors and available to prospective investors are prepared largely from the stewardship point of view. Management has an obligation to investors and prospective investors to provide information which wi11 serve as a basis for decisions as well as to fulfill its stewardship responsibility. The Study Group on Business Income says: "The annual financial statements of corporations are primarily reports of stewardship, and the methods of presentation should be determined wth constant regard to that primary purpose; but when corporations seok the advantage of marketability for their securities they incur an obligation of disclosuro to investors generally" (3. p. 108).

The investor must make certain docisions concerning his investment. Should he retain or terminate his investment in a given enterprise? If he terminates his investment, should he invest in other entitios? 
If ho retains his investiaent, should he increase or decrease 1t? These are some of the most important decistons to be made.

The type of inforration used and needed by investors is difficult to determine because investors' motives are not easy to analyze. The investor may be intorested in dividends, appreciation, risk, and diversity. Any given investor might assign different weights to these various motives. Sone investors may be unable to analyze their motives. It is likely that many investors have nerer tried to do so. Institutional investors are likely to have more defintte motives than incividual investors. Investors must have rather clearly defined motives in order to use rinancial statements orfectively in the decisionmaking process.

Unce the investor has estabilshed his motives for the investraent he must determine how his investment measures up to the motives. Mis is best dono by comparing an investmont with alternative investmonts. Also, a comparison of the financial statemonts rrom year to year may indicate trends.

The potential investor faces essontially the same decisions as a current invostor. The main difference is that comparison must bo made between the present use of money and the prospactive investment as well as betwoen alternative investments and uses. 
Creditors and Prospctive Creditors

creditors are interested in the debtor's financial ability and willingness to repay debts. The willingess factor is important but rather difficult to evaluate. A debtor's reputation and his financial status are guides to his willin zness to repay debts. The better off financially a debtor is, the more likely he is willin:; to repay debts. It is generally assumod that a dobtor is willing to ropay debts if he has a good reputation and is rinancially able to do so. Creditors are seldom raced with the need to raako decisions concerning current debts. There is usually nothing to do oxcept wait for the maturity of the principle, or perhaps to colloct intorest payments and instaliments on the principle. Bven when they aro not raced with decisions, creditors are interested in the debtor's ability to repay debts. This will involve short-run ability or long-run ability dopending on the lenzth of the loan period.

The general-purpose flnancial statements are used to help determine a rirm's financial ability to rupay dobts. The relationship of current assets to current liabilitios is a mide to short-run ability to repay debts. The debtor's earning power and the size of other long-term dobts are puiles to long-run ability to repay debts. The jeneral-purpose financial 
statements are intended to prosent this type of inforration.

There are times and situations which require decisions by creditors concerning outstanding debts. The contract between the debtor and creditor may require the debtor to perform specific acts. For example, he may be required to place funds into a spocial sinking fund for the retirement of the debt. The creditor wants to know if the debtor is meeting such requirements.

There is the possibility that credit obligations such as notes and bonds may be sold to others before their maturity. The croditor doos not necossarily havo to hold an obligation until meturity. A decision may be made at any time to torminate a given credit position. There is the possibility that legal proceedings may be necossary to collect a debt from a debtor. Sometimes a croditor will find it nooessary to initiate legal proceedings: even bankruptcy proceedings may be necessary. The croditor needs to be in a position to foresee the necessity of such proceedings.

For the prospective oreditor or the creditor who is considering making additional loans to a debtor, decisions must be mado concerning whether or not to wake a 1oan. What amount to loan, and what contraotual requirements are to be imposed upon the debtor. The published financial statoments of the debtor may bo holprul in making these decisions. More detall than 
is usually included in the published financial statements is desired by the prospective creditor. Additional information may be obtained through more detalled statoments or through porsonal interviews with the debtor (or prospective debtor) or his representatives. Information is also avaliable from those who are already faniliar with the oredit standing of the prospective debtor.

Social Control Agencies

Social control agenolos usually prescribe their own form of accounting statements. Theso statements, usually prepared by the ontities themselves or their agents, provide the basis for various types of taxes and controls. The social control agencies also use aocounting statements in making decisions concerning types of control, types and amounts of taxes, and means of enforcing rogulations.

\section{Labor Unions}

\section{Labor untons are interested in ascertaining}

the financial condition of tho entities in which its nembers are employed. The unions' main objectives are to determine what benerits to ask for and to determine a bargaining procedure.

Smployees, consumers, and the Eeneral public as a group have less specific needs than other groups of users. In general they are interested in products 
and services being sold at ralr prices and ractors of production being paid falr prices.

\section{Comparison or Internal and External Users}

In the preceding paragraphs, many of the various uses made of acoounting statements by internal and external users have been briefly sumarized. For internal users, the type of information and the quantity of detall depends upon the level of responsibility and authority. The lower levels require more detail than higher lovols. The published financial statements, or "general purpose" rinanoial statements, are not designed to cover specific areas of responsibility and give the amount of detail needed by lower levels of management. Higher levels of management are more $11 \mathrm{kely}$ to find the published finanolal statements useful. However, this is Iikely to be just a starting point for analyzing the operations of an entlty. It is likely that top management does not desire detalls of every item in the rinancial statements; only certain 1 tems require more detail.

Moonitz emphasizes the different needs of

internal and external users in taking the position that :

publishod financial statements (usually in the form of annual reports to stockholders) should be designed to inform all important nonmanagerial groups by presenting a report on management, not for management. . . We can no longer, however, operate on the assumption of a harmony of intorests, 
that what is good reporting for investors is also good reporting for menagement, and vice-versa... . The investor is interested in results, not in mothods of decision-making by management (4, p. 179).

Investors, creditors, and other external users need information about the plans and accomplishments of management in order to make the best decisions. The needs of managoment, in general, differ from the external users. Or course, vartous levels of management need Inforation on the effectiveness of lower levels over which they have responsibility. Management needs information for planning, control, and evaluating. This requires much more information than that contained in the published rinancial statements.

\section{Purpose}

The significance of accounting is reflected by the use made of accounting statements and other accounting information by those internal and external to the entity. These users and their general needs have been presented.

The ways in which accounting statements are used and the reasons for their use are not dorinite. This has been the subject of some recent research, and it is $11 k e 1 y$ that even more researoh will bo conducted in this area in the near future. Although some of this research ut111zes the deductive approach, the empirical approach is more common. It is assumed in this study that accounting statements are read and that the 
readers utilize the information for tho decision-making process. "It is ovident that accounting measuroments do represent information for deciston-makers and sinoe decision-makers do read accounting reports, the impl1cation is strong that acoounting measuremonts must have specific behavioral implications, not mere general tendencies in the long run" (5, p. 212).

Assuming the baste needs of those who use accounting information, this writer feols that the basic problem in accounting is the method of measurement to be used. For example, investors may wish to know the amount of income earned over a given period of time. Various anounts of income would be determined, deponding upon tho mothod used to measure income as several methods are availablo.

The purpose of this paper is to analyzo and compare the most prominent of the measureant methods, or bases. The measurement bases chosen for Inciusion are historical cost. current cost, net realizable value, and discounted cash flow.

Tho writor hopes that this study will provide the reader with:

1. An understanding of the major moasuromont (valuation) basos by oxplaining oach, oxplainIng and comparing the different interpretations for each. 
2. A dononstration of the 11kely errect of oach of the bases on tho moasurament of rinancial position and periodic income.

\section{Scope}

This study is propared largoly from the point of view of business enterprises, 1. ... enterprisos organized for profit. This is not to say that it has no application to entitios such as hospitals, charitable organizations, and aunicipalities, but that the emphasis is on business entorprises.

One of the most important concepts underlying accounting as practiced today is original cost. or historical cost. This conoept is generally accepted in the determination of periodic incowe. The use of thls concept may havo cortain weaknossos. It may result In asset values on the balance sheet which do not reflect the worth of the assets. If asset value increases or decreases are sometimes not recognized. palns or losses occur which may not appear on the income statement. Revenue may be thought of as being earned throughout the production and selling process or throughout the solling and rendoring of sorvioes. Whon the historical cost concept is used, revenue is not usually recognized in the accounting rocords until a speciflo event such as a sale takes place. These weaknesses may be used as the basis for the suggestion 
that there may bo alternatives to the historical cost concest which would be more useful. The major portion of this study is a discussion of those alcernatives. The principles of measurement anil their inoortance and application to accounting are discussod in Chapter 1f. It is cmphasized that accounting is a system of mrasurement.

chapter fII is a discussion of the prosentig generally accepted meosurement ooncept-aistorical cost. the writer's intentions are to show the impact of the historical cost concept alon: with a relatod concept, the realization concept, on the accountins statements and especially on tho income statements. Weaknesses already referred to aro discussed in detail in order to suwest the neod for alternative meosurement coricepts. Chapter IV is a discussion of current cost. Current cost is a name chosen by this writer to enconpass several concepts which include market valuo. opportunity cost, and replacemont cost. A11 the concepts in this arca are divided into two caterories which are discussed separately. Uno category includos all current costs which would inclucle production inoome before a sale takes place, while tine other catogory oxcludes such curront costs.

Just as thero are soveral variations of what thls writer refers to as current cost there are al so 
soveral variations of not roajizable value. Chapter V is a discussion of these concopts.

The discountacl cash flow concept is discussed in Chapter VI. This may be reforrad to as tha econouic concest of income.

Chasters IV, V, an I VI include a comparison of tho measurenent base presented in that chapter with the neasuremont: base (or bases) presanted in iho prior chapter (or chapters). Thus, oach of the four moasurement corcopts oresented is compared ivith all of tho uther three noasuroment concepts.

The sumary and conclusions constitute Chapter YI.

\section{Method}

This stuly is based on library researeh and loflcal analysis. No empirical study has been utilized. Extensive empirical rescarch would be necossary to determine how accounting statoments are actual1y used, the rellance placed upon thes, the chanpes desirud by statement users. and the measurement methods which would bo most useful to users. For lack of such rosearch, tho writer relies upon his own assumptions and the assumptions which have been made by other writers. 
CHAPTISR Il

MEASUREMLNT IN ACCOUNTING

\section{Introduction}

Neasurement was at one time closely bound to mathematics. It is perhaps difficult to say whethor measurement had its boginning in mathematics or wathematics had its beginning in measurement. whole-number arithmetic and scales of numerosity (called numbering; in common usage) grew up togethor. "The numorosity of collections of objocts. . constitutes the oldest and one of the most basic scales of measurement" (6. $\mathrm{p}, 19-20)$.

The lica that measurement theory applies to accounting is not new. Accounting has always been concerned with moasurement just as it has been concerned with aritlumotic. There has been an increased emphasis recentiy in the application of measurement theory to the social sclences which include accounting.

The first part of this chapter is a discussion of measurement thoory. Types of scales and kinds of measurement are included. Tho application of 
measurement theory to accounting is discussed in the second half of this chapter.

\section{The Nature of Moasurement}

In common usage the terms "measurement" and "measure" have a multitude of meanings. As used in this paper the terms have much more narrow inoanings than in common usage. Several definitions or measurement as used here are given in the following paragraph. S. S. Stevens, one of the leaders in the field of modern measurement theory, defines measurement as "the assigninent of numerals to objects or events according to rule--any rule" (6, p. 19). B. liusse11. another authority on the subject, lves this derinition: "Heasurement of magnitudes is, in its most general sense, any method by which a unique and reciprocal correspondence is established between all or some of the magnitudes of a kind and all or some of the numbers, intogral, rational, or real as the case may be" (7, p. 176, quoted in 8, p. 13). N. R. Campbell gives a definition very similar to that given by Russe11. Measurement is "tho assignment of numerals to represent properties of material systeas other than number. In virtue of the laws governing these properties" (9. quoted in 8, p. 13).

warren S. Torgerson points out that, though there are slipht differonces in these definitions, all three deal with the same general problem concerning 
"the process and rationalo involved in the construction of a scale or measuring device and the properties that can be ascribed to it" (8, p. 13). In common usage measurement usually rofers to the application of a scale; in this paper measurement refers to the construotion of a scale. "Measurement as used here refers to the procass by which the yardstick is developed, and not to ils use onco it has been estabilished..." (8. 2.14$).$

According to Torgerson, an object is not theasured; properties of an object ere measured. ("Proportios aro essentialjy the observable aspects or characteristios of the empirical world" [8, p. 9].) The dorjuztions of Russell and Campbell given above Indicate that properties are measured rather than objects. Sterens' derinition indicates that objects themselvos can bo measured.

Stevens considers his definition to be loss restrictive. "Restrictive definitions of measurement have toppled as the practico of measurement, outrunninks logislation, has forced us to broaden and gengralize our conceptions" (6, p. 18). Stevens considers his definition "liberal and open-handed" and realizes it is unacceptable to same $(6,9.18)$. His definition includes mere classification as a form of measuromont. 


\section{Types of scales}

Heasurenent of properties requires the assionment of numerals to represent the propertios. A oneto-one relationship must exlst betwoen the quantities of the properties and tho number system. The number system used must have the following foatures:

1. ()rdered numbers,

2. wderod differences between numbers,

3. A unique origin, "zero."

These threo reatures may be called order, distance, and origin (is, pp. 14-15).

when numbors are assigned to objects "so that the relations between the numbers rerlect the relations between the objects themsolves with respect to the property" (8), a scaie of measurement has becn estab1 ished.

uf the three characteristics 11 sted above

(order, distance, and orizin). only order is necessarily involved in the usual meaning of theasurement. Tho other two characteristics may or may not be involved in a given measurement. If a scale necessarily involves order but may or may not involve distanoe and origin. thore are four possible combinations of these three characteristics as presented in rable 1 (8, [. 16). urder is implied in the ordinal scale "so that the order of the numbers corresponds to the order of magnitude of the instances" ( $8, p, 16)$. The interval 
scale has the feature of the ordinal scale with an added feature of a meaningful size of the distance between pairs of numbers. An interval scale with a natural orifin is called a ratio scale (8, p. 16).

\section{TABLE 1}

FOUR TYPES OF SCALHS

No Natural Origin

Ordinal.

Scale

Uis tares
Interval

Scale
Natural Origin

Ordinal Scale

with Natural

orisin

Ratio

Scalo

stevens adds to these conventional scales a lower scale which he calls the nominal scalo (soe Stevens' table on tho rollowing page--Table 2) (6. p. 25). "An array of categories or classes made distinct through the label of numerals is considered to be the natural basis of measurement and is called the nominal scalo." (10, p. 58). The ordinal scalo is next in hierarchy. [t "consists of classes-characterized by numerals- which are subjoct to order rank in conformity with the numerals assigned" (10, p. 59). Tho next scale, the interval scale. onforces regularity of class-interval. The last scale, tho ratio scalo, requires a zero-point that is not arbitrarily chosen but piven somehow beyond mere convention" (10, p. 59). 
TNMLS 2

A GLABSIFICATIJN OF SCALTS OF MZASU:23MEHT*

Scale Basic unpirical Matheinatical Typical

uperations Groill itructure ixamples

Nominal Deterinination Permutation "Numbering" or

of equality roup

$x^{\prime}=f(x)$

where $f(x)$

moans any

footbal1 players

Assienment of typo

or mociol numbers

to classos

one-to-ono

substitution

Ordinal Dosormination or greater or loss

Isotonic erou
$x^{\prime}=f(x)$
where $r(x)$
means any
increasing
monotonic
runction
Linoar or
afrine group
$x^{\prime}=a x+b$
$a>0$

Hardness of

minerals

jtreer numburs

Grades of leather, lumber, wool, otc.

Intellipence test

raw scores

Interval Determination or the

acuality of

intervals or

of differences

Teaperature

(Fahrenheit

or Celsius)

Position

Fine (caiondar)

Enerpy

(potential)

Intelisence

test "standard

scores" (?)

Ratio

Betermination

Similarity

Nuacrosity

of the

equality

of ratios

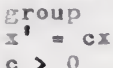

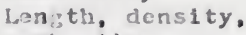

work, time

intervel, etc.

Temperature

(Pankine or

Kelvin)

Louciness (sones)

Brightress (brils)

* Measurement is the assigninent or numerals to events or objects according to rule. The rules for four kinds of scales are tabulated above. The basic operations ncodod to create a given scale aro all those $1 \mathrm{isted}$ in the second column, down to and including the operation listed opposite the scalo. The third colum eives the mathematical transformations that leave the scale form invariant. Any numeral $x$ on a scale can be replaced by another numeral $x^{\prime}$, where $x^{\prime}$ is the function of $x$ listed in column 3 . 
The nominal scalo involves the assignment of numerals to the object itsolf rathor than to the properties of the object. This would not be considered measurement at all by some derinjtions such as the conventional definitions eiven by Russell and Campbell. Thus, stevens considers mere classification as measurement while some authorities would not (8, p. 9 ). Stevens also includos some examples in the other scalas which may not, by derinition, be considered noasurement by Russoll. and Campbell. Ho incluAes street numbers as an exemple of the ordinal scalo. position as an cxample of the intorval soalo, and nunerosiby as an example of the ratio scale.

$$
\text { Sturens elpes not recoonize an ordinal seale }
$$
ivith a naturel sigin. Authorities other than Stevons asd Turgerson presont still nore variations in scalos. jach of stovens" scales after the rirst "prows out of the preceiling one by introducing an additional propurty or condition, thus restricting, its application to a smallor but more spesific area than that of the preceding seale" (10, p. 58). The classification of sealo: is basod on how much information is rouresented by the Humorals (8, 2. 2l). The amount of freodom in assigning numbors decráses as ono goos down the scalo-either Stevons' or tho conventional scales. 


\section{Ninds of Heasurement}

Hinds of inforination roprosented by numerals "ainounts to a consideration of the sorts of meanin: atributed in a particular scale to those characteristics of urder. distance, and orip,in that are represented" (3, 21). Torzerson Bives three ways in which those characteristics mi pht oblain meanine:

1. Mrough laws relatin? the property to other properties-miderived measurements.

2. "y arbitrary definition--fiat mosurement.

3. Through natural laws relatin? various quantities of the construct to each other--fundanental measurement (8, PP. 21-22).

There is no necessary relationship between typos of scales and kinds of measuroment. A particular scale of measurcment is not limited to any particular kind of measursment (8, p. 22).

"The view has boen held that the assignment of nuiberals to objects other than by the prucedures Involved in fundamental or clerived measurement is not measurement at all" (6, p. 22). Some experts disapreo with this and reel that a more general definition is neederl to include flat measurements. 


\section{Impact or Mensurement on Acoomintina}

\section{Definitions of Accounting}

Accounting. by definition, is concerned with

measurement. It is fenerally accepted that financial

data is the subject of the measurement process.

"Accounting is a discipline concerned with

tho quantitative description and projection of the

income circulation and of wealth aggregates by means of a mothod basod on the rollowing set of basic

assumptions: monetary values, time intervals, structure, duality, asgregation, economic objocts, inequity or monetary claims, economic agents, entitios, economic transactions, valuation, realization, classification, data insut, duration, extension, materiality, and allocation" (10, p. 19). Quantitative description, as used in this dofinition, implies measurement.

Accounting is tho art of measuring and communcating rinancial inforation. This stateuent is not shocking or even surprising, yet the acknowlodgerart that accounting is cancernod with measurement is the first necessary step towards a Ione awalted revolution in accounting. This revolution is not rostrictod to accounting; it has already taken place in other disciplines where measurement is crucial. For examplo, the classical concepts of measurement in physics and psychology have already undergone drastic changes. It is tirio for rostrictive definitions of moasurement in accounting to topplo (11.p. 501).

Accounting might even be considered a theory or measurement: "Since the main rurctions of accountInt are classification and evaluation, the thought of 
interpreting accumbancy as a il:eury of theasurement is not faprotiched anci souncls plausible" (10, s. 54).

Those are Iepresentative derinitions or accountIne which enphasise the neasurement aspect.

\section{Inportance of Measuroment in Accounting}

Galileo demonstrated "that quantification is

the best and most accurate way to scquiro empirical knowledge." Ho indlcated the aaxim in this proverb: "Measure all that is muasurable and atterpt to make measurable that which is not yet so" (10, pp. 54-55).

"The basis of eccountine is measurement" (12, p. ix). The purpose of accounting is to measure. Or perhaps the purposo of accountirg could bo better exprossed as: to measure financial data. Financial data nay be arranged in the form of financial statements. Thus, the two primary financial statements measure financial position and the results of operations. other sinarcial statements measure changes in retained carnings, tho flow of working capital, and the rlow or cash. Accounting may also be usod to moasure financial data such as the cost of products, variations botwoen tho actual and standard costs of products, and the differences in costs and revenues between alternatives.

Veasurement is concernod with the quantitative aspects of objocts. By tradition, at least, accounting is concerned with the quantitative aspeots of objects. 
Pexhaps nocountine thovid on cancarned uith other

espectis; perhavis secounfing sholld roport fact:s and contingensics which ito not have a dixuet impacti ipon cuantitatire asprets of objccts. A heart attack surfered by the prosiclent of a businoss corporation ray be of more interest to the stockholders than much of the data thet is reported-whe nmount of goodwill carried on the books, for exesujle. Traditionaly, goodwill carried on the corporation's books is reported on the balance sheet; a heart attack surfered by the president is not mentioned in the financial statements. It may be argued that the president's heart attack will be reflected in tho financial statements in the future by means of reducesl profitability, but thore is a time 1ag. Thore aro those who argue, or at least suggest. the possibility of extending accounting to nonquantitative aspects of objects.

The requiremert that measuremont be "in terks of money" has porgisted, dominating the notions of "simificaist mannar" and "ovonts." Mpon ain evont: occurs whose impact may be hi phly significant for tho fluagial (or other) velfors of an entity, tho decision to rocord it or not in the occounting reooxis wi.11 be nade on the basig of whother it can be expressed in terms of monoy; consecuentiy evonts of a trivial nature aro recortod whtl movontous occurrences which ars cuantifiable but to which a dollar valug cancot be attachat--c.8., doubling sluare of market, number of lost sales-or nonquantifiable events, such as tho choice of a next president, are efrectively i gnored (13. p. 28).

By tradition, accounting has confined it a quantitative measurement larioly to monetary terms. Heasurement of othor quantitative aspects of objects. 
such as the shysical units of prociuction during a given month, is within tho range of accounting, but such measurement has not gained the status of measurement in monetary terins.

\section{Basic Structure of the Business Measuranent Process}

The rollowing structure of tho businoss moasuromont process has been suggested by daui Kircher:

1. Deterinination of the objectives of the business ontity- the purpose which is to be served in a particular situation.

2. Determination of the types or factors which aight serve to attain the objective.

3. Selection of the key aspects of the factors-the aspects which are to be moasured.

4. Choice or:

(a) a moasuring method;

(b) a racusuring unit.

5. Application of the rovasuring unit to the object to bo mersured-otho central action of measuroment.

6. Analysis of the measuremont--relating it to other ineasurcments (otiser in time or in inind).

7. isvaluating the efrectiveness or the measurement by detornining the extent to which it assisted in the attainiment of the objective (14, p. 68). "A central problem we face is to define the properties of a tusiness for 'attributes,' as some have callod them) that accouriting should seck to measure" (15. p. 257). The rirst three components of the structuro are important but not includod within the main purpose of this paper. The profit motivo is usually 
assumci to be the primary purpose of business enterprise. kntities otfic than business entities have other objectives.

The main purpose of business firms is to increase the economic resources under their control throngh their activities. Even thouph business rirms have many other objectives, their success or failure is primarily evaluated on the basis of the increase or decrease in the economic resources over which they have control (16, p. 151).

The subgoals of business enterprise have been given more attention in recent years than before. Subgoals may include importance in industry, growth, cash flows, customer goodwi11, and public sorvice. It is difricult to moasure subgoals. "In most cases our ability to isolate specific benefits from a general system is inadequate and we are simply not able to Eenerate enough information for meaningful uneasurements" (137. p. 24). Therefore, the assumption is raade in this paper that accounting is primarily concerned with the measuroment of profit.

The selling of products and the rendering of services are usually considered to be the means of obtaining the objectsos. The financial aspocts of rendering services and solling products are the key aspects to be neasured. "Accounting measurement is primarily concerned with the measurement of assets and incone" (18. p. 151). As has alroady been sugpested. there are accountants who suggest the extention of measuroment to aspects other than finanoial aspects. 
sxtencied ciscussion of this point is not within the scope of this stucy.

Accountants cannot always measure what they want to aussur.. If the Frimary goal of a tusiness ontersise is to mairo a prorit, nccounting should measuro the amount of profit. There is no perrect vay to measure prorit. "Tro accountant's approach to this problem is to substitute somothinf that can bo moasured for the tilings wo would like to moasure if wo ware inore competent" (19. p. 90). This is reforrod to as using surrogates, or substitutes. "Mccounting data as well as other types of business information are surrogates whlch tho docision-maker uses to carry out the decision process" (20, p. 192).

The basic moasuromont task of accounting is the selection of a moasuring method and a moesuring unit. The moasuring urit is the languago in which the rosults may be expressad. The cholcs of a language is one of the decisfons a isasurer must mako. "Tho masurer must dovolop a languago which adequately conranicates to anotiaes person what tio user rast do to utiliza the Laroration coatained in tie measuromant" (2l, p. 85). A dilemina arises ln tho salection of a language. C. wost Churchman has expressed tire dilema this way:

The clearer a language the more confusing it is to most people. Precise languages narrow the class of users but increaso the degree of refinement that any user can attain. The proper balance betweon 
breadth and depth is tho Inguistic decision problem of measurement (21, p. 87 ).

Accounting expresses financial data in monetary terms. Trus, in the United States, the language of accounting is usually the dollar. The selection of the dollar as the measuring unit does not solve the measuring unit problem. A significant dirficulty to bo solved concerns how to deal with the changing purchasing power of a dollar. Are measurements to be made in terms of dollars with no rocognition made of the changed purchasing power between two points in time? "Measurements of financial position and income based on numbers of dollars without regard for any differences in the econonic significance of those dollars are cruder economic ineasurements than we are capable of providing" (22, p. 110$)$.

The choice of a measuring method is the centrai theme of this paper. "Income and wealth are dependent upon the choice of measurement rules" (16, p. 221). Several possibilitios are suggested, discussed, and compared. "Accounting is a measurement system which is plagued by tise existence of alternative measurement methods" (23, p. 474$)$.

The fifth part of the structure is the act of applyinf a moasurement method. This is moasurement according to the common use of tho word and is not relovant to this study. 
The sixth component of the structure is the uso, or application, of the rosults of the measurenent. This use actualiy has implications for the selection of a measuring method and a measuring unit. "The measurement procedures underlying any set of accounting inforination are inevitably linkod to the purpose for which that information is provided" (22, p. 101 ).

In advocating measurement procedures in accounting. it is mandatory at the outset to specify the purpose for which the measurements are intended. The attribute to be measured and the unit of measuremont to be utilized thon must be demonstrably consistent with that purpose (22, p. 102$).$

If the primary goal of a business enterprise

is to rake a profit, then accounting should make a contribution toward this goal. Accounting should make a contribution to whatever the goals of a business mifht be. Therefore, ovaluating the effectiveness of the measurement in attaining an entity's objectives is an integral part of the moasurement process.

The final results of the measurement process is really tho deciding factor in determining which measurement method and unit is best. According to Ijiri. "if people are likely to behave in a more 'desirable' manner in response to the values of assets and income prepared under one set of woights than under another set of weights, then and only then we can say that one set of welghts is better than another" (18, p. 161). 
Corl Devine has sot forth the following similar list es typical conditions (and preconditions) for accoursinz measurement :

1. Specifying and ordering worthy objectives;

2. Joternining decisions and information neodod to accomplish objectives;

3. Identifyine and ordering individuals with legitimate clairos to information;

4. Uecicing which events aro rolevant to achieving these objectives;

5. Dociding what aspects of tho events should be abstracted;

6. Adopting a set of feasible measurument scales and rules that will yield an advanco in objectives $(17$, p. 17$)$.

Number three is the only condition listed by bovine which is essentially different from those listed by Kircher. Jovine points out that an ethical aspect is involved in ordering individuals and that accounting should be concerned with this ethical aspect.

\section{Measurcincmt and Value}

Heasurement is a tern which has gained prestige in tiso field of accountirg in recent years. As measurement implies (or reprosents) accuracy, it possibly is used as a status syinbol. Rerhaps the uso of masurement in tho physical scionces is imitatod by the social sciences.

sprouse says accountants are really talkinb about the asasurement of value. "The relovant attribute with which we are essentially concerned is that 
of value; the neasurement process in which we are fundamentally engaged may bo properly described as valuation" (22, p. 107). The tern moasurement is used because of tho emotional effect of the use of the term value. "The terms value and valuation have an unfortunate tendency to arouso omotional reactions among soms . . "(22, D. 107). By using the word measurement. accountants may avoid using the word valuation. "Measurement, on the other hand, is an innocuous term as well as a prestigious one; it is not branded with the emotional stigma attached to valuation" (22, pp. 107-8).

Sprouse believes that accountants should recognize valuation as the relevant attribute in reporting to the stockholders of a business enterprise. The financial accounting process "could be improved enormously by a clear-cut recognition of value as the relevant attribute"(22, p. 108).

R. J. Chambors has a difrerent view of the relationship botween measuroment and valuation. "It seems - . that greater clarity or argument is possible if the distinction is made between acts of valuation which always have reference to the future, and acts of measurement which have reference to the past and present" (24, p. 32). Chambers bolieves accountants are interested in measurement--not valuation. Most accountants, as Sprouse, do not mako such a distinction. 


\section{Accuracy}

In common usage, measurement implies accuracy. Results of measuremont (numerals) are often taken as fact. A given person welghs one hundred sixty pounds. A room is fifteen fect wide and toenty-four reet ing. Thes masureinonts may not bo accurato. The givon porson may woigh one hundred sixty pounds and three ounces. The measurement could be even more nearly exact, using even sinalier units than gunces. There are degrees of accuracy; it is not essential to bo completely accurate. In fact complete accuracy may be impossible. Complete accuracy wight not be recognized if obtained.

Tise deireo of accuracy to be obtained by any measurement (accounting or othor) depends upon the purpose for which the measurement is made. If a room is being measured. for wa11-to-wa11. carpet, the measuremont should be within porhaps one-fourth inch of the actual dimensions. Ir the dimensions are obtained to determine the number of square reet per student for testing purposes, measurements might woll be rounded off to the nearost foot.

\section{Accuracy in Scionces}

The physical sciences are sometimes thought of as boing exact. Chambers says "the presumption that the exact sciences provido measurements which are paragons of accuracy is false" (24, p. 45). Evon in 
the exact scimces, "the dogrec of accuracy sompht is

tho derree necessary for practical purposes" (24, p. 45).

Chabuers apjles this idea to accounting. The

current cash equivalent (his proposed measurement) cen

bo found for al.2 assets with somo deeree of accuracy $(24, i), 26)$.

Probablity and Degreo of brror

Complete accuracy in accounting is never possiblo. Furthormure, it may bo impractical to obtain cumplete accuracy or highly accurate data even if it were possible. Thorefore, the user of financial data should be aware of the degroo of accuracy reflected in tho rinancial data being utilized. Poriaps financial statoiants should indicate tho probability and degree of error iniserent in measurement methods used and in tho results of tire raeasurement. "The information of measurement is considerably enhanced if the degree of accuracy or error of the pertinent ineasurement is known" (10, p. Bo).

Probability has been given very little consideration in accounting al though it is interesting to notice that "the usual ordering of assets on the balance sheet, by chance or otherwise, tends to follow tho level of confidence in the measuroments" 117. P. 22$)$.

The accountant's attempts to disclose precision are crude indeed, but, worse, it is possible that lie omits important information $81 m p y$ 
becauso his methods of conveying precision are so crude. A littlo-explored alternativo estimates probability numbers for both the amount to bo paid and tho possibility of having to pay at all and derivos an expocted valuo for the unfavorable prospect $(17$, p. 22$)$.

\section{Scales in Accounting:}

Stevens' nominal scale would include tho chart

of accounts within the range of measurement.

With the rejection of Stevens' approach, the designation of freasurement would be unduly denied to those systems. "Unduly," because these systems still axtract significant information for comparison in research and practical decision making. information that often can efficiently be transmittod by numerals only (10, p. 63).

The nominal scalo although basic to the accounting process is neither tho only nor the most important scale pertaining to our discipline. The evaluation provess--tha core of theoretical accountancy--utilizes the ratio scale; statement analysts prituarily work with ordinal scales; and certain aspocts of cost accounting can be considered as applying the interval scale (10, p. 68).

Standard costing is an example of the use of the intorval scalo. The dollar scale is a ratio scale.

"There arc, however, instancos of muliple maasurement, the dimensions of which are masured on scales that differ frow each other; the accounting transaction is one of these cases..." (10, p. 7t). The chart of accounts (nominal scale) is used in classifying the dablts and the crodits of a transaction. The timo dimonsion is moasured by an interval scale. The dollar amount is measured on a ratio scalo. 


\section{Kinds of Mersuromant in Accountin?}

"Most of the sconomic and accounting mensures

belong in the category of measuremont by fiat, which

is reflected in a certain definitional arbitrariness

of our discipline" (10, P. 79). Mattessich emphasizes

that neither fundamental nor derived measuremont is

used to much extont in accounting:

There neither exists at present the possibility to infer accounting values throurh "ratural laws" (i.e., by fundamental measurement) nor through a combination of two or more fundanental measures that result in derived measuremont. Most of the economic and accounting measuros belong in the category of measurement by fiat, which is roflected in a certain definitional arbitrariness of our discipline (10, p. 79).

Carl T. Devine feels that attempts by rorgerson. Mattessioh, and othors to rind fundamontal moasurements tend to be fruitless ondeavors.

Measurement is a process that requires extremely hish levels of abstraction. In this sense all measurement is riat measuroment, for some identifiable property mist be isolated and related to objectives (17, p. 14).

Sprouse suggests, on the other hand, that direct measuroments are orten used in accounting. Examples include the measurement of assets such as receivables and payables (22, p. 111). He reoognizos

the fact that fiat measurement is more of ten used.

The value of an asset can bo measured directly only if infornation is avaliable concerning amounts of future cash flows, timing of such cash flows, and the appropriate rate of discount. In addition, if the future cash flows are measured in dollars. either it must be assumed that the purchasing power of the dollar is constant or inforination concerning future price-level changos is required. 
In the abscnco of sufficlanty roliable information about these factors. direct measurement of the value of an asset is not feasible: Indirect ineasuroment procedures, such as the use of acquisition cost and tire 1150 of roplaciant cost, iasst be adopted (22, p. 111).

\section{Criteria for Comparlu Measurement the thods}

Wo Anerican Accounting Asociation's $\Lambda$ Statement of Basic Acoountin. Theory published in 1966 suggested the followling four accounting standards:

$$
\begin{aligned}
& \text { 1. Relevance (Usorulness) } \\
& \text { 2. Voriflability } \\
& \text { 3. Freedon from bias } \\
& \text { 4. Luantiriability }(25, p, 7) .
\end{aligned}
$$

These four accounting standards mielit wabl servo as critcria for tine selection of the most appropiato moasuremont nothod.

The Harvard Business School Accounting Round Table held in 1964 prosented a slightly difforant set of criteria for moasuroment:

\section{Ubjoctivity}

Two related requifroments:

(a) Certain standards should be used in presenting financial accounting information, and

(b) It should be feasible to vorify rinancial accountinz inforination.

2. Userulness

3. Feasibility (25, pp, 18-19). 
f. conbination of those criteria will be useo in discussing and conjaring the various aeasurement methuds. The conbined list follows:

1. holevance (Usofulnoss)

2. otjectivity

(a) Verifiability

(b) Freudon frum bias

3. Euasibility

4. uaritifiablity

\section{Sumina $\mathrm{ry}$}

Mbasurenont is the assignnent of numerals to objects or properties of objects to reprosent such objects or properties. Accounting. as it rolates to quantification, is a system of measurament.

iiveasuremont is an intogral part of the physical sciences and the suciul soiences. The nature of moasuranunt has beon discussed in rathar broad terms in this chaptor because fao asuremont thoory applios to such a broad area.

Heasurument theory has beon related to accountIng in the lattar part of the chaptor in more specific terms. It was concluded that the selection of a moasurement aethod is one of tho inost sienificant problems of accounting. 
CHAPTER III

HISTURICAL COST

\section{Introduction}

Mis chapter is the first in a series of four chaptors wich discuss major measurement inethods, or bases. Hoe prescrit chapter is a study of a measurement base which may bo called historical cost (or original cost). Ilistorical cost is generally accopted for use in accountiris statements. This chapter is iargely a discussion and criticisin of accounting statewents as they are currently preparod.

The chapter begins with a definition of historical cost. This is followed by a discussion of some related concepts which underly the preparation of accountins statements. As the realization concept and the historical cost concept are closely relatod the realization concept is of particular concorn in this chapter. The historical dovelopraent of the roalization concept is followed by a discussion of the present status of the concept.

The last part of the chapter concerns the effects of historical cost and related concepts, 
espeoially the roallzation concept, on accounting statemants. The use of this measurement basis is criticized.

\section{Dorinition of Historical Cost}

Accounting statoments are prepared in terins of historical, or original, cost. When assets are acquired they are recorded at cost, a measure of the current exchange value at that timo. Historical cost is the cost arrived at in the transaction concerned; historical cost is transaction price. A record is made when a transaction occurs betweon an enterprise and another party. Tro dollar amount of the transaction is considered to be an objective basis for the valuation of that which is exchangod. This dollar amount, transaction price, is the historical cost of that which is recordad. Assots romain on the books at cost for cost adjusted for such factors as depreciation) as long as they are owned by tho enterprise.

There are a few oxceptions in practice to the historical cost concept, but in general when an enterprise oxpects to operate inderinitely, the original cost concept, or historical cost concept, is adhered to in the preparation of accounting statements. The following quote probably represents the attitude of accountants as exemplified in practice. 
costs and revenues to the current and succeeding fiscal periods. . . If values other than unamortized costs are to be quoted they should bo expressed. . . only as collateral notations for information purposes. . . There seems to be no sound reason for ropeated adjustiments of asset values for the ordinary chanisos in price lovels commoniy experienced from one foneration to another. - A histury of cost and cost arortization is a consistent record or actual occurrences... and constitutes an essential starting point in rinancial intorprotations (27, pp. 61-62).

This quote from the 1936 American Accounting

Association statement (A Tentativo Statement of Accounting rrinciples Underlying Corporate Financial State-

monts) represented the attitude of the ixccutive coninitteo at that time toward historical cost.

The historical cost concept is criticized with varying degrees of severeness. As an illustration a quote is oiven here froin Harry N. Kamph:

Conventional balance sheets and operating statements have becone so distorted that they are of little or no guidance for decision-naking purposes.

Whout taking into oonsideration current values, we find it imposibio to reach valid conclusions or develop fully revealing information on such inportant natters as:

1. Return on total capital employed.

2. Return on capital equity or stockholders' investinent.

3. Optimum mortgage loan financine terms.

4. Necessary coverage under fire and comprohensivo insurance polictos and proof of loss.

5. Evaluation of specific segments of an operation or an entire business for purposes of purchase, sale or merger. 
6. Costs and profits measured in terms of current values rather than often misleading book or original values (28, p. 17).

\section{Related Concepts Underlying Accounting statements}

The following concepts are closely related to the historical cost concept and also, 1ike the historical cost concept, underlie the accounting statements. Presently accepted methods of accounting include all of these concepts.

\section{Going Concern}

There was a time when the venture was the predominant rorm of business enterprise. As vontures lasted for only a relatively short period of time, an accounting was usually made only at the end of the venture. The venturo rorm or business enterprise is almost completoly gone. It has been replaced by business enterprises which remain in existence for long periods of tima. Although thousands of enterprises go out of existence ach year, a majority of business enterprises, espocially medium and large-size ones, have lives of indefinite length.

Since business enterprises usually operate for long periods of time and are not expected to discontinue in the immediate ruture, they may be assumed to have a continuous 1 ife. This "continuity concept," or "going concern concept," assumes that business 
enterprises reinain in oxistenco indefinitoly unloss there is evifonce to the contrary.

Accounting statements are generally prepared on this assumption. Mio primary impact of this concept is on tho valuation of assets. This assuaption has iaplicatiors for income noasuranent duo to the interrolationship of the balance sheet and the income statement.

Acountants have generally felt that since liquidation values may be of 1 ittle importance to a going concern, this continuity of life concopt is used as justification for another concept, the cost concept. The following quotation from Henry Rand Hatrield's Modern Accounting points out the insignificance or liquidation values.

The proper value is that which thoy have to tho holding concern, and not that which they might have to other persons, whether these persons are ordinary custumers, or those who inipht bid on the assets at a liquidation sale. The value is that which they have to tixe company as thon existin and not to a company in the hands of a receivar. or one cloging up its accounts and going jut of business $(29$, p. 81$)$.

This quote does not mention how to arrive at the value to the holding concern. This does not necessarily imply a historical cost basis. Reed $K$. Storoy quotos Hatfield as saying the going concern is not usually takon to its logical oonclusion which would be to value merchandise at net realizable value. A loglcal. application of the going concern concept would 
be the masurement of firol assets at cost becauso changes in volue from ane poriod to another which aro not expectad to be realized by the salo of the flrod asset are not as relovant as changes in value of current assets, espietally those which will be coaverted into cash in tho noar futire. Storey says, "Mhe fallure to carry the going concosn assuaption to its iogices conclusion left a gap in accounting theory which was rilled by the reajization concept" (30, p. 237).

It is the reajization convention which reciuires valuation of all unsealized (i. e... unsold) assets at cost, whether they be rixed assets or unsold invontories.

The area of complementarity between tho realization and going cencern conventions lies in the area of rixed assets, whereas the area of basic conflict lies in the area of current assets.... In this aroa the realization convention is clearly dominant in modern accounting (30, pp. 237-38).

\section{Tirac Periods}

Under the venture forn of business enterprise, an accounting was made uipon tha completion of tire venture. The amount of rusiness incone earned can bost bo determined at that thae. Whon there is continuity of lifo, it is not fasible to wait until the end of the enterprise life to measure incone.

\section{The time-period conrention has doreloped to} broak the life of on entarprise into arbitrary time poriods. This arbitrary timo portod is usually a year. The calendar year is used hy many enterprisos. This may be a carryover from an agricultural society in 
which the calendar year was the natural business year. Many business enterprisus are now using what is cunsidered a matural businoss yaar for their particular type of business.

Accounting: ror a business entity by time periods Gives interosted partios userul information about tho enterprise before its life is over. Somo accuracy is socririced for timeliness.

\section{Realization}

Since accounting; attempts to measure income by timo periods there raust be a criterion to determine when income arises. The roalization cuncept has developed to noet this need. The dominant interpretation is that a change in value has taken place with sufficient objectivity to warrant recognition in the accounts. A salo is usually thought of as having sufficiont objectivity and is generally the accepted criterion for realization. The roalization concapt is related to the original cost concept in tarat assets are rocorded at original cost until realization is doaned to have taken placo.

The development of the realization concept halped bring about the development of the historloal cost concopt. "The assertion by the court of the realization postulate lent support to tho proposition that, until realized, assets should be carried at cost. 
and thus contributed to the building up in accounting literature of a so-called 'traditional cost principle'" (3.

Like the historical cost concept, the realization concept is also based on transaction price. No increase in the value or an asset is reoorded until another transaction occurs. The realization concept dolays the recognition of revenue until a sale or some other sufficiently objective ovent occurs. This means that the usefulness of accounting may be impaired by the time delay.

No doubt, overyone would like tinely reports that are also conclusive, but for the most part the two conditions (timeiinass and conclusiveness) are in conflict. In most cases accountants have chosen to be more conclusive rather than more timely in their recognition of changes that have occurred, the reby exposing themselves to the charge that their reports (issued at frequent intervals) are less userul than they could be (31, pp. 33-34).

In emphasizing the importance of the evaluation of past deoisions, isdwards and Bell point out that "if the denand for data is predicated largely upon the existence of change and uncertainty in the econony, accountinf, data, to be most useful, should be designed to report changes as they occur" (32, pp. 5-6).

Like the historical cost concept, the realization concept results in some liaftations in the determination of periodic income. The realization concept will be discussed in more detall in a subsequent section of this chapter. Enough has been said to 
indicate that the realization concept may limit the userulness of accounting statements.

\author{
Matching?
}

While the realization concept deterinines the period in which revenue is to be recognized, tho matching concept determines what costs becone oxpensos to be matched against revonue. The matching concept moans that those costs which were necessary to attain the revenue of the period should be ratched with the revenue. The exponses which apply to a given period aro those which can be natched with the revenue which is rocognized during that period. The following statement is made in the 1957 revision of Accounting and Reportins standards for corporate Financial stateinents: "The conmittee advocates that costs (derined as product and service ractors given up) should be related to revenues realized within a specific period on the basis of some discernible positive correlation of such costs with the recognized revenues" (33, P. 369 ).

In all significant cases where there is uncertainty, revenue is the controlling classification. It becomes the guide to action, the rocal point which makes matching efrectual in areas of uncortainty (34, p. 738).

The matching procoss developod when the "Increased not worth" concept gave way to the "realization" test of income. "It becamo common to speak of income determination as being essentially a process of ratching 
costs and revenues" (3, p. 28). The timine of revenue recognition deteruines to a largo extent the timing of expense recognition and therefore the timing of net income recognition. Matching is nocossary to determine the not increase in assets which is similar to "increased net worth" because net assets equal net worth.

\section{Objectivity}

Objectivity is difricult to define. $\Lambda$ koy word in the definition of objectivity is "unbiased."

Naurice Moonitz defines objectivity as "unbiased, subject to verification by another competont investigator" (31. p. 42). This implies that many individuals would reach approximately the same conclusions.

llarold L. Arinet gives the following explanation or objectivity:

Finauclat information is objective when:

1. It is free from personal opinion and bias, which further requires

a. that there actualiy be an exchange of sumothing for something. both having "value." and

(1) this exchange bo the rosult of an arm's length transaction between independent parties.

(2) this exchange be capable of being accurately measurable in dollars.

(3) that one of the negotiating parties in the exchange be the unit for which the accounting is being dono.

2. It is substantiatod or capablo of being substantiated by an indopendent investipator (35. p. 65). 
Thore aro dogroos of objectivity. Accuracy is signifloant in doternining vhether or not data is objective. "If an itein can be measured with reasonable accuracy. it assumes a large defree or objectivity" (36, p. 251).

Ubjectivity is considered to be an outstanding characteristic of historical cost and the realization concept.

\section{Conservatisn}

Conservatism is sometims axpressed as: Provide for all losses; anticisate no propits. Paul Grady. $1.7 \mathrm{~h}$ Inventory of Genorally Accepted Accounting Principles ror usinoss enterorisos, explains tio concept of conservatisa as follows:

Iron the viewpoint of Eenerally acoepted accounting principles, the concept of conservatism comprehends the twin ideas that:

Sales, revenue and incone aro not to be anticipatod. Recognition ordinarily requires consummation or sale and delivery, and

All known liabilities or losses should be recorded regardiess of whether the definite amounts aro determinablo $(37, p .36)$.

Grady notes the close relationship botween the conservatisin concopt and the realization concept by saying that the abovo iloas "often havo been doalt with as a separate concept of 'realization" (37, p. 36). Conservatisin is actually a technique for delayint; the recognition of revonuo. Roalization and conservatisu are related because tho realization concept 
is a fairly conservative concept in that profits are not anticipated very rar in advance or tho actual receipt of cash. Cash receipts would usually be tho most conservative method of rocognizing roverue. Thore are excoptions to this statement such as the advanco of cash before a product is dolivared or services are rendered.

IIstorical cost is also a conservative concept. The lower-of-cost-or-market valuation method of inventory valuation is oven more conservative.

\section{Sumary}

The concepts discussed above are considered anong tho most basic accounting concepts. It is generally rocognized that the use of these concegts along With otror cunerally accepted accounting principles and procudures results in accounting statements which havo I I mitations.

Tisis discussion of these basic concepts is intonded to show that accounting stetenents are knowingly propared under assumptions which will not result in perfection. It is the purpose of a latter section or this chapter to point out woaknesses in accounting statements due to the uso of these concepts. It is tiso purpose of subsoguont chaptors to discuss altornative measuroment basos which inight result in better accounting statorents. 
Historical cost may bo thought of as tho moasurewont base which is largoly controlling in the proparation of accounting statements. It is closely rolated to the other concepts discussod here, but it is especially related to the realization concept. The realization concept may bo thought of as the application of the historical cost concept. Hecause of the importance of tho realization concept in current-day accounting, the following section of this chapter is devoted to this topic.

\section{The Roalization Concopt}

The realization concept is the currontly accopted basis for revenue recognition. According to the nost ccinmonly accepted meaning of realization, revenue should be recognized whon a salo takes place. There aro other meanires for realization and criteria for recognition as are indicated later in this section. This section considers the historical developinent of the concept and its prosent status.

Historical Derolopment of the Roalization Concopt

The Study Group on Business Income points out that the postulate of roalization is of quite modern oripin:

A review of accountins, legal, and economic 1 iterature suggests that tho realization postulate was rot accojted prior to the first iorld har. In 1913 leading authoritios in all these fields in 
Groat Lritain and Amorica suorad to agree on the "increase in net worth" concept of income (except in the vase of "pormanant" onterprises), though the way in which it could best be implemented was not settled, and unrealized appreciation was not perhaps deemed to be a part of "income from operations" (3, p?. 23-24).

As an examplo, the Study Croup quoted the

following statement by 1 . L. Delkinson in his Accounting rroctico and Procedure (1913):

In the widest possible viev, profits may be stated as the realized increment in value of the whole amount invested in an undertaking: and. cunversely, loss is the realized decrement in such value. Inasmuch, however, as the ultimate realization of the original investment is rrom the nature of things deferred for a long period of years, during shich partial roalizations ara continualiy taking place, it becomes necessary to ra.l back on estirates or palue at certain definite periods, and to consider as profit or loss the estimated. Incriase or decrease between any two such periods (3, p. 24).

W. A. Paton also accepted an increase in value

theory. He makes the rollowing statoment in his

Accountinp Theory. published in 1922:

Tho liberal view that, 1deally, all bona fide value changes in elther direction, from whatever cause, should be reflected in the accounts has been adopted without argunent. . . This logical position is the proper one for the professional accountant, at least as a starting point 138 , P. vill.

In these early years of the current century. the realization concept did not have its current status. The events of the times probably brought about the almost complete acceptance of the realization concept. The sixteenth armendmont in 1913 may have had a great effect on tho creation and acceptanco of the 
soalization conespt (3, 2,26$)$. Tho zarduark case of

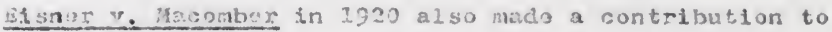
tho roul1zation corcopt, In this docision, Charles Evans Iughos said:

It is of the ossance of incoms that it should be roalized. . . Income necossarily implies separatlan and ronjzzation. . . The incraage in tho valuo of lands due to erowth prosperity of the commnity is not incono until it is renlized (Bisner v. Macombor, 25 U. S. 138, 195 [1920].). The economic exporionco of the $1930^{\prime} \mathrm{s}$ faily woll finalizod the olfmination of the tncrase-invalue concopt.

The roalization concept hal zafned accoptanco by $193^{\prime}$ a: evideneed by tio first of six ruios is principies adoptod by the Aaerican Institute of sccountants that year: "Profte is doenod to bo realized whon a salo in tho ordinary courso of business is orfocted. unless tho circumstancos aro such that tie collection of tho salo price is not reassonabiy assurec" (39. p. 4:23i.

The Present Status

Realization is currontly tho genorally accopted critovion for revonue reogaltion. Recognition rerers to the timing of rocording revenuo on the books of an enterprise. The realization concopt, used as a guide to revenue recognition, is primarily a timing device. "The tost or realization is used to deterinino whon to recognize e particular iton" (36, p. 251). "The entire 
income from sale arises at the noment whon realization Is decmod to take place" (3, pp. 19-20). Heoause costs and revenues are matched to determine income, income is assumed to arise when the recognition of revenue takes place.

Thero aro somo differences of optinion on the exact moaning of the roalization concept. The 1957 Statement by the American Accountine Association Cominittee on Concapts and Standards Underlying Corporate Financial Statements defines the realization concept as fo110ws:

The essential meanine of realization is that a change in an asset or liability has becomo sufficiently definite and objective to warrant rocognition in the accounts. This recognition may rest on an exchango transaction between independent parties. or on establishod trade practices. or on terins of a contract performance of which is considered to bo virtually certain. It may depond on the stability of a banking system, tho enforceability of commercial agreements, or the ability of a highly organized market to facilitate the conversion of an asset into another form (27, p. 3).

The key words in this definition are "change" and "sufficiently defint te and objective." According to Floyd w. Windal. this definition implies that "the change may have taken place prior to tho time it became sufficiently definito and objective for recognition" (36. p. 251).

Floyd w. Windal defines realization by using the throe key ideas from the definition just quoted:

The realization of income takes place--that 1s, income cones into existence--when cortain criteria have been fulfilied in connection with 
a not asset incroase. Hxcluded are increases caused by gifts or additional owner investment. Among other criterin ire these:

․ The Eafin or increase must bo confirmod by sume event or transaction such as the receipt of cash or property. relief rroin liability, or a change in the nature of legal rights.

2. The gain or increase must be subject to objectivo mensuremont.

3. The gain or incroase must be derinite and irrevocable (40, p. 36$)$.

Inherent in these definitions is the criterion that revenue must have been economically earned before or at the point it is recognized (41, p. 43). "Economically earned" means that a value increment has taken place due to the operations of an enterprise. "Revenues are effectively earred when substantially all of these nctivities necessary for and associated with the production of those revenues have been completed" (4I. p. 4(t).

olher criteria have been used in determining when roalization takes place. Hobort $T$. Sprouso and Maurice Moonitz list tests which have been used to dotermine if an item is realized or not:

1. It had to be earned.

2. It had to be the result of a conversion brought about in a transaction between the enterpriso and someone external to it.

3. It had to be the result of a legal sale or similar process (related to 2. above).

4. It had to be sevored from capital. 
5. It had to bo in distributable forn (related to 4, above).

6. It had to be evidenced by liquid assets (related to 5, above).

7. Its efrects on the onterprise had to be the subject of accurate measurement or of estimates with a high degroe of reliability ( 2 . pp. 14-15).

The Amorican Accounting Association 1964 Concepts and Standards Research Study Cormittee on The Realization Concept also presents its view of the realization concept:

when should realization be considered to have been achieved in a revenue transaction? Three ractors have genorally been considerod surficient in answering this question:

1. The nature or the asset received;

2. The presence of a market transaction;

3. The extent to which services have been performed (42, p. 314 ).

It is difficult to be procise about what is the current provailing practice, but it appears that presently accepted tests for realization require receipt of a current (or liquid) asset capable of objective measurement in a market transaction for services rendered (42, p. 314 ).

The 1957 statement has been amended by the work of this 1964 Concepts and Standards Research Study Committee. The conclusions of the compittee cannot be classified as generally accopted. In this sense. the conclusions and recommendations cannot be considerod as part of the present status of the realization concept. They are included here because they have been made, and in this sense they arfect the present status of realization. 
The following two problens were discussed by

the comittoe:

1. Transactions assoclated with tho exchango or goods and services between the accounting entity and some indopendent, external froup. These aro rerorred to . . as revenue transactions.

2. Changes in the value of resources during the time they are held by the firm. Those are rererred tu.. as holding gains and losses (42. p. 313).

The conalteo arrived at these conclusions:

"The combittee unanimously reoomends that the effects of changes in value of all assets, other than goodwi11, that can be supported by adocquate evidenoe be racorded in tho accounts" (42, $p .312)$. "A majority or the comittee recomands that 'unrealized' changes in the value of assets should not be included in the computation of reported net income, but should be shown on the incoine statement below the net income 1ine" (42, p. 312).

In considering when realization should be regarded to havo been achieved in a rovenue transaction, the comittee made the following docisions:

1. Nature of Asset Roceived--The comraittoe recoumends continued adherence to a policy of requiring objective evidence of the valuation of the asset received before rocognizing realized revonue. . . The comittoe would stress measurability, and not liquidity, as the essential attribute required for recognition of realized revenue.

2. Presence of a Markot Transaction--There is Eeneral acceptance of the view that a market transaction is necessary for revenue to be roalized. The comittae concurs in this requirement. 
3. Gxtent of Service Performed--Traditionaliy, in establishing a realization test, accountants have considered the depree to which the seller has furnished the services being purchased. The comittee is suggesting that another factor is more relovant, nanely. whether the seller has performed an action which is the crucial ovent in the process of earning revenue. This crucial event may be something distinct from the rendering of services to the customer (42, pp. 315-16).

There is often some confusion between the teras "recognition" and "realization." Kobert T. Sprouse has mado some obsorvations concerning this confusion. "Prior to 1957, the term 'realization' was widely used and I think generally understood" (43. p. 522). The general meaning of realization was expressed by the Paton and Littleton monograph:

Revenue is realized, according to the dominant viow, when it is avidenced by cash receipts or roceivables, or other now liquid assets. Implicit here are two tests: (1) conversion through legal sale or similar process; (2) validation throuph the acquisition of 1 lquid assets (44. p. 49).

The definition given in the 1957 Revision sugested that revenue is realized when it can be recognized in the accounts. Sprouse refors to this as a "drastically different concept of realization. - - This concept renders realization devold of any special meaning; realization is made merely a synonym for recognition" (43, p. 522).

The two terms, realization and recognition. are often used interohangeably. As the realization concept is presently accepted as a zuide in the timing of revenue recognition, then realization and recognition 
take place at the same time. The eccurrence of one implies the occurrence of the other. In common usage, the two iarms orten imply the seme thing.

Recognition of revenue on the basis of the roalization concept coes not necessarily imply that it is the only "corroct" nothod of recognizing revenue. Sprouse and Moonitz express this idea as follows:

Reliance on "realization" for the recopnition of profit does not imply that prorit arises only at the moment of sale. Instead it implios something that may or may not be true in a given set of circumstances, namely, that satisfactory results emerge if prorit is consistently recognized only at time of salo (2, p. 11).

\section{Currently accepted exceptions}

To the fieneral rule for realization

$$
\text { Although in current practlce realization is }
$$

usually deened to take place at the point of salo. there ars exceptions to this general rule. For example. In unusual circumstances realization is deemed to take place when physical production occurs rather than when a sale takes place. In order for realization to take place due to physical production, "production must be accomplished either by a binding contract for salo of the product or by a market of a certain character" (45. p. 94). Cortain metals (such as gold. silver. and copper). rarm products (such as cotton, whoat, corn, oats, rye, soy beans, barley, raw sugar, and cofree beans), crude oil, and securities moet these requiroments. The market price or contract price is 
used as basis for dotormintng rovente. Market price may be usod although it may vary somewhat from period to period.

A change in value between the date of coinpleted production and the dato of sale does not imply that early rocognition was incorrect. Russell Bowers makes the following statement concerning whoat:

The quoted price used in the inventory mipht diffor from the price of sale, but this pain or loss need not be looked. upon as an error in making tho previous estimate of ralue. It is proporly assicned to the period between the date of completed physical production and date of sale and should bo attributed to speculation rather than to wheat growing. Any gain or loss could of course be analyzed into interest, storage service, and market fluctuation (45. p. 95).

Even incomplete physical production may be appropriate for realization to take place. Howers suggests three ways in which income may bo objectively measured which are particularly applicable to incompleted contracts:

1. A completed transaction between parties of independent interest.

2. Apportionment between fiscal periods on an objectively determinable basis, the total for the various periods being determined by a completed contract.

3. Ieference to price in a market of a certain recognized character (45. p. 105).

Shipbuilding is one example of incomplete physical production in which it is customary to recognize revenue before physical production is complete and legal title is conveyed to the purchaser. 
otlus prosently acsoptod excentions to th? roalization rulo include replacoment costs in cost-oraarkt calculations, index numbers of specific commodities or froups of similar comnodities in dollar - value Lifo, ari estinates of net realizable value of byjroducts and obsolete zoods and equipment.

Thase soveral axecptions to the raalization concejt irilicato hat cursent practice covers a fairly wide rango. Jarman $C$. 31 ough has omphasigod the wide rango of practice in considering incoue to be realized:

At what tine, or in what stage of a transaction should income be considered as having boon realizod? While it is fenerally understood that income should be recognized when services are rendored or goods delivorsd, in practice the timo of taking it up rangos all the way from the time of production, as in the case of some mining enterprises, to tho time the cash is receivud, as is sometines done in the case of installment sales (46, p. 39$)$.

\section{Surnatary}

The realization concept is a fairly recent devolopment in accounting. having derelopod oarly in the present century. At present it is a generaily accepted concopt.

The usual interpretation of the realization concept is that rovonuo ray bo recognizid when a sale takes place. Realization is the usual Euide, or criterion, to revenue recognition. There are some exceptions to the general interpretation of the realization concept. bxoeptions involve the valuation of 
assots such as certain metals, agricultural produots, socuritios, and othor assots such as ships which roquire an unusually long period of time for construction.

\section{Effects on Accounting Statements And Criticisms}

Accounting statements are currently prepared

under the historical cost concept or measurement. As has been pointed out, the realization concept is an important concept related to this measuremont base. The purpose of this section is to point out some of the shortcomings which rosult when the historical cost measurement baso is usod.

Accountants themselves recognize shortcomings in accounting statements. Howard I. Ross made the rollowing statement in a prosidential address at an annual meeting of the Canadian Institute of Chartered Accountants: "The basio problem which I would like to concentrate on today is posed by the paradoxical fact that accountants appear to divide their time. perhaps almost equally, between preaching, on the one hand, the great importance of publishing regular financial statements and insisting. on the other hand. that one who rolies on financial statements, in almost any of the circumstances in which one would normally turn to them, is 1 ikely to be mislead" (47, p. 68). 
An obvious problen inherent in the use of the

historical cost concapt is that accounting data do not reflect valuos (axcept by chance). (It should be remembared that historical cost is not intended to measure value.) Tho following quote by Edwards and

Bel1 emplyasizes this in discussing the effect of the application of the realization concept:

Instead of assuning tho identity of cost and value, accountants have actopted the convention of recognizing profit only upon sale; no pretense is made of measuring profit as it accrues either in production or as a rosult of simply holding assets as thoir prices risa. Reporting assets at historic cost represonts a consistent apolication of this convention; a rocord at market value would involve a recosinition of gain prior to sale. Those who use accounting data are falriy warned by this convention tirat the interpretation of a firm's position or operation on the basis of market value is not the responsibility of the accountant as record-kooper. The accountant shares the interprotative resporsibility with other nombers of manageinent, however $(32, \mathrm{p}, 10)$.

Even though a statemont user may realizo that

the statements were prepared under the realization

concopt. it is likely that he may not roalize the full

inplications of the use of this concept. Lidwards and

Bell point out the following two 1 imitations which

result froin the use of the realization convention:

1. Within the framework of prosent accounting practices, no capital gains or losses aro recorded as they arise, i.e.. as individual prices change; this linitation in turn has three main implications:

a. The capital gains (losses) for any one period aro incomplete; 1.0., they are not recognizod until the assets aro sold or used in the produotion of goods which are sold. and profit is therofore understated. (overstated): 
b. Sumc sapital balns (lossis) of rormer periods are recognized as capital gains (losises) of this period when assets which have risen in price over an extended period of time are sold in this period, thus overstating (understating) profit;

c. Balanoo sheot values aro badly distorted.

2. Capital gains and losses which are realized through uso of an asset whoso prico has changed and the subsequent salo of the product for which the assot was used Ero inciuciod as part of normal operating profit although the profit results fron holling activities rather thon usine actlvities per se; thus difficulty stems from keeping records at original surclase cost with the result. for example, that one of the expense desictions rrom operating revenue is depreciation based on the historlc cost value of the rixed asset (32, pip. $10-11)$.

Theso 1 imitations result because the roalization conveution requiros a sazes transaction. The concept does not recognizo holdinf, gains and losses. 1. e.. changes in individual prices. Another major limitation implicit in the use of the realization convention is the failure to rocognize changes in value as production takes place and as services are rendered.

The realization convontion has the erfect of assigning to just une stop--the saie--in a whole series of steps the ontire credit for having earned the resulting income. Since "income accrues to an Individual or a business in somethling liks a continuous stroan," It may be illogical to assign all income to enly one step (48, pp. $80-81)$.

In defense of tho salo as a test of Income realized, "it is the last vital step in the longer 
business process shich indicates that tho task is nuw complotid and the lucoue rully earned" (43, p. 81).

The objectivas of accounting statoments were discussed Eenerally in Chapter I in terms of those who use them. In that chapter no attempt was made to ovaiuate how wel1 accounting statements neet their objectives. Sone comonts rill nuw be made concorning how well accounting statomonts preparad under the historical cost basis of measurament moet the objoctives. Just as the objectives were classified by types of users, these comants concerning how well objectives are not will be by type of user except that the probloms of comparability and uniformity aro discussed. rirst as thise tivo problems are faced by both oxternal and internal statemont usors.

\section{Comparability}

Both internal and extornal users of accounting statements are interested in comparability, that is, comparing the accounting statoments of a particular entity over a period of time. Comparison of these statements should indicate trends.

Accounting statements for different periods may not be comparable for two principal roasons: alternative methods and price-lovel changes.

\section{Alternative methods}

Generally accepted accounting principles include alternative methods of handiling some problems. (However. 
"generally accejted aocounting principlos" should be appliod consistontly from yoar to year.) If a mothod of handling a problen is changed, the effect of this ohange should bo shown for the yeax in whlch the change took place. Comparability is lost if a chango in method is not oxjlained. Conparability is also lost betwoen the years berore the change and years subsoguent to tho change.

The possibility of using alternative mothods In accounting not only presents the problem of comparability but also presents the question of how difforent managerial decisions would be if an alternative method had been used. This involves the problem of comparison or actual rosults with what would have occurred under alternative procedures. Although business games have boen used to determine the effect of alternative procedures, conclusive evidence has not beon found. Willam J. Bruns, Jr., after using business games, decided that "for most of the decisions and results, there were no major differences in results among the games using different inventory valuation methods" (49. p. 349). Un the other hand. Thomas $\because$. Dyckman reached the opposite conclusion in one study but the same conclusion in a second study $(50,2.175)$.

\section{Price-level changes}

Although historical cost is used in accounting statement preparation, it is an accepted fact that the 
price levol has risen substantially during the prst fow decades. Thase price-level changes may cause an entity to appoar to be rrowino faster than it is. The assets currently purchased, espeoially the rixed assets, usually cost more than thoy did in the past. Thus, an entity may appear to own more assets than it did in the rast. (on the other hand, if most of an entity's assets were purchased at a low price level, it will not compore well in sixe with other entities.

Net income is also affected by the price-level chances. If costs orisinc in past periods are matched against revenue of the current period, the net incone anpears hicher during periods of increasing price levels than it would during a period of stable or decreasine prices. For example, inventories used or sold during a period may have been acquired in prior periods at lower prices. For another example, dopreciation is basod on costs of fixed assets acquired in prior periods--perhaps forty or fifty years before tho current period.

Arthur L. Thomas has made the following observation concerninf the price-level problom: "It is difficult to seg how a rate of return con mean much whon it is calculated in terins of a inixed afgregate of unlike historical costs-osome current, some stale, somo oripinating so far back in time as virtually to be from another oconomy" (51, p. 576$)$. 
l'rica-ievol chanbeg anay be eluousht of as goneral pricu-jevel changes arci specific pricentevel chemges. As all prices sio not aovo tugother, prices of spocific itoms may bo called specific prico levels. Tho foneral price lovel is an avexage or specific prices. It is ouviuks that speciric pulco changus aro not necessarily cursistent with generai prico-bevel chargas; thoy may even ba in tho opjusitu direction.

this iaplies that an adjustment for goneral prico lovels ay not rosult in comparability betwoon accounting poriods. An adjustaent ror a goneral priceIevoi chanjo would rasult in comparability only if each specific itou in the accuunting stacoments involved a specific stice-level change oqual tu the Eeneral priceLUVel cisango.

\section{Uniforaity}

Comparability of accountinp, statements between enterprises is often roferred to as the problem of unirorinity. Just as there are two principal reasons for lack of comparability between accounting statements of various years for a particular enterprise, there are also a few pilncipal reasons for lack of comparison betwoen entities.

\section{Alternative rathods}

The protiam of alternative mothods arisos here a1so. A company may be able to chooso from soveral 
available methods of handling any particular problem of recording and reporting rinancial data. Even entities within a givan industry do rot nocessarily choose the saine methods. A lack of comparability resuzts. Some writers are severely critical of manazement's use of altornatives. (Aocounting methods are often the choice or anangement. Important axcoptions are public utilities and other rosulated entitios. stevon s. Anreder is an exanglo of such writers. In an article in tharron's. Anreder says:

There are many acinowledged alternatives by which oarnings can legally be exaggerated or miniraizod. . . . Accounting varics from industry to lndustry. In fact, eron amonis companis in tha same fiell practices are so diverse as to mako comparisons of varulngs less tiran meaniugrul (52, 1. 3$)$.

\section{Judginent}

\section{Another reason for the lack of uniformity}

betwoen companies is the need for and dependence upon judgment. Judgment varios from ontity to entity. Moonitz suggests that less reliance may be placed upon judgrient in the ruture. but it is needed at the present:

As the basic analytical framowork of accounting becoues mure rismly astablished and nork widely accoptod, specific rules can be sot according to

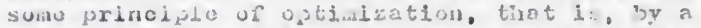
balancing of conflicting forces, such as the cost of cata accunulation, thu accuracy of line results. the benerits to be derived rron the resultant data, and tho like. Ultiuataly the optimal solution may evon be deterininablo by analytical means. Yean-

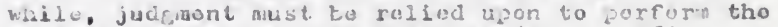
runction of more formal analysis (31, p. 36). 


\section{Price-level changes}

The prico level is algo involved in comparisons botwoun entitios. This includes both tho problem of the general prico levol and tho problem of sipocific price lovels.

A comparison of accounting statements may involve the accounting statoments for different entities for just one yoar. ( $\Lambda$ comparison betwoen ontitios should include the statements for several yoars. As the problem of comparison within an enterprise has just been considered, it will not be reconsiderod hero.) Prico-lovol changes are a problem largely because various entitios acquirod thoir assots at various points in tiac at various price levels. This rosults in loss of comparability in both the balanco sheet and the income statement as the assets themselves appear in the balance sheet and explred assets appear as expenses in the income statement.

\section{Management}

Assuming a well-organized enterprise, it would seem that management (internal users of accounting statements) should receive or be in a position to acguire any type of information they desire as long as it is possible and economically feasible. They also should have the opportunity to discuss, the statements with those who prepare them. 
This may not always be tho case. Managers may not understand accounting well enougl to know what concepts underlie the preparation of accounting statements and the resulting inherent 1 imitations of the stateuonts. As a result, managers may think accounting statements provide more information then they actually do provide or that thoy are more accurate than is actually the case.

On the other hand. suppose managers do have a thorough knowledge of accounting. They recosnizo tho Jimitations which exist. This means they must make certain adjustments and allovances on their own. This implies a lesser degrea or reliance upon accounting statements than would be the case if accounting statements provided moro accurate and complete inrormation. Menagers are interested in comparison--both couparison of the entity wich they manage with other entitios and comparison of the current period with previous periods. Such comparisons are essential to the management areas of planning. controlling. and evaluating. The problems of alternative methods and price-level changes and the 1 initations caused by concepts such as realization are drawbacks to management.

Invostors and trospective Investors Investors and prospective invostors are faced with docisiuns concerning buying, holding. or seliling 
stocks. If published financial statements accurately presented financial position and rosults of operations. thon these statements would be vory usoful to investors and prospectiro investors in making decisions.

Many Investors and prospective investors do not make their clecisions on the basis of published finenciel statements. This could be die to ono or more of several ractors:

1. Published rinancial statements may not give aclecuate information to form the basis for a docision.

2. Other 30 reses of information may bo more holpfil.

3. Investors and prospective investors may not have sufficient knowledge of accounting to use the published financial statements.

Each of theso three possibilitios probably has some validity. Published financial statements do not give rul1 and completely accurate inforination about the entity. This is partly due to the use of the accounting concepts which are used in statement preparation and which have already been discussed. The limitation on statoment userulness causad by lack of conjarability between accounting periods and accounting entities has also been discussed. The published financial statements may be so condensed that they fail to give enough inforation. 
The annual report may be tho only contact inost investors have with a conpany. Since the publishod financial statoments aro preparad lareely for livestors and prospective investors, the statements may be somewhat biased. This is possible even when they are certified by independent certified public accountants. This is possible due to the alternative aocounting inothods. the possibility of manipulating prorits to some extent, variations in presentation in tho published financial statements, and failure to emphasize unfavorable events and contingent events as much as the favorable onos.

The annual reports of 1 arzo corporations usually include the financial statements, a message from tho president or chairman of the board of directors. and other information concerning ractors such as products, growth, and plans for the future. These annual reports tond to present a rosy outlook. It is highly possible that, instead of trying to present all relevant information as accurately and completely as is possiblo and practical, annual reports may attempt to conceal information.

rublished financial statements may be of rather Limited use evon to those who are familiar with accounting bocause they may intentionally withhold inrormation or present information in an abbiguous way. William 11. Dinsmore emphasizes this in a recent article in 
Harper's Magayinu. He believes that corporate reports-"orie of tho flosilest and laast informetive art forms of our time" (53, p. 133)--go unread by most of the present 17,000,000 stockholders. This is because the report provides such 11 ttlo information. "Aftor revisions through countloss drarts by accountants, allditors. treasurers, banker-directors, laryors, union nogotiators, ensineers, sciontists, and purchasing agents, the typieal corporate mossage ends up freighted with vague Eonerallzations, clichés, halr-truths, total omissions, unsubstaniated claims, and downright distortions" (53. p. 134). Dinsmore believes the corporate report has lagged far bahind the time. Thers are millions of small investors now who want a report they can read and uso.

Joa1 Daan 1ists the following posstble reasons that managomont may desire to $11 \mathrm{mit}$ the amount of profit reportad:

1. To discourage potential compatitors.

2. To woo the voting public and restrain the zoal of antitrusters.

3. To restrain wage demands of organized labor.

4. To maintain customer good will.

5. To keep control undiluted.

6. To maintain pleasant working conditions ( 54 , p. 29).

Another criticisin of published financial statements is that they provide investors with vory litte 
information concerning the future. Perhaps it is best not to publish plans because this information would become available to competitors. However, the suggestion is soiretimes unacie to include managenent's pians in the published financial statements. Morton Backer wakes such a sugeestion which he recognizes to be a significant doparture from current practice. His suggostion is based on throe propositions:

1. Decisiuns are mado on future expectations;

2. Flanning is a fundamental management responsibility;

3. Stockholders are entitled to a knowledge of management's profit plan and an explanation of the causes for subsequent variations $(55$. pp. 59-60).

Thuugit there soetas to be no general agreement

as to the purposes financial statements sorve for investurs, ilobert L. Uickens and John U. Biackburn suggest these two to sum up the goals of external roporiing:

a. Tu pruvide the best possible basis for the stockholder to project the earnings and rinancial condition of a corporation.

b. Tu provicie the best possible basis for evaluating the performance of manapement (56, p. 314 ). whether manapement attempts to jimit or ennecal information or not, it is obvious that puhlished annual reports could provide better information to fuide invostors and prospoctivo invostors in making decisions. 
The second possibility suggested above as to why investors and prospective investors do not use published financial statements in making decisions is that other sources or information may bo moro helprul. This could involvo a secondary use of the published financial statements. Investors and prospectivo investors may acquire information from those who have carerully studied financial statements. The primary user or the statements then would be the invostment oxperts such as investment brokers, rinancial periodicals and news reports, and investment managers for institutional investors. If investorg rely on secondary sources or information, this could indicate that either they do not possess sufficient knowledge of accounting to use the statoments or they do not have the time for do not oonsider it worthwhile to use their time) to study statoments thomselvas.

Anothor sourco of information which investors and prospective investors may consider more userul than publishod financial statements is the "hot tip" source. The hot tip is information concerning whether or not to buy, hold, or sell stock. It does not ooms directly or indirectly from the published statements and is supposediy not available to the general public. If the hot tip is reliable it usually comes from a source of information on the inside of an ontity. Such information usually loaks out against 
the wishes of management as a whole. Such information may or may not bo reltable, and the use of such information is not a reflection uson the published finansial statements.

Still another source of information used by investors ant prospectivo investors as a basis for locistons is tive racord of dividents paid by entitios. It has alraady beon pointed out that investors are Anterested in one or nore factors such as dividends, approciation, safoty. and livorsity. If this invostor is primarily intorosted in dividonds, thon tho dividend reoord is espootally signifioant. Gntitios are prevented by law from paying dividends sut of capital unloss so Jasignater. Tho invostor rany be assurod that tho antity has enried at lonst as mich income as the dividend payment indieates. Diviciend rocords are not intended to toll tha wholo story. Mividonds paid in one period may excood the earnings for that poriod, as they may bo paid from the earnings of urior periods. The dividend policy of an entity is arrected by 1 ts reported oarnings. Invastors and prospective investors would be wise to consider the pulilshed financial statoments along with the dividencl rocords even thoulh their primary interost may be in dividends.

Another source of information of ton used by invostors and prospactive invostors is the daily roport or activities and prices on the stock markets. Mis 
information is certainly moro current than annual reports can be. Observation or prices on the stuck market over a pertod of time roveals trends which are useful in making decisions, especially to investors interested largely in appreciation.

Reaction to stock-market prices may be based on decisions already made. That is, a decision may have boen made to hold stocks for a long period of time. Day-tonday activities may be of interest to such investors, but they w111 probably not be the basis for a decision.

Such investors, interested in the long run rather than day-to-day activities, may compose a fairly 1arge group. A majority of stockholders are women. It is $11 k e l y$ that many of these women have inherited stock from their deceased husbands and depend upon dividends from such stock as a portion of their income. Stockholders in this category are interested primarily in the long run.

Un the other hand, an investor may have decided to marimize his income in the short run. Thus, he will buy. se11, or hold at least partly on the basis of dally stock-market activities. The use of stock-market activities in making decisions is not necessarily an indication that published financial statements fall short of their objectives. Instead, different objectives are rulfillod. Financial statements arrect the market 
prices of stocks, especially in the long run. Charles r. Horngron has said that the long-run stock prices aro probably influonesd by earnings per share moro than by any other sinele ractor (57, p. 564).

It is apparont, then, that there are sources of information wich are more userul to investors and potantial investors than are published financial statements. This is partiy because other sources of information may provide a different typo of information and met different objectivos. It is also because statement users do not have an adequate knowledge of accounting or because published financial statements do not prosent relevant data as woll as they could.

The third possibility suggosted above as to why investors and prospective investors do not use published rinancial statements in making decisions is that they may not possess surficient knowledgo of accounting. Such investors must rely on other sources of information. It is perhaps worse for one who is not informed in accounting to attempt to use rinancial statoments than to rely entirely on other sources of Information.

Accounting statements could be more useful to investors if they were propared in such a way that they could be understood and used by those who aro not orports in accounting. Arthur M. Cannon has sald: 
ractors. . I du not uant to have to hire another expert to interpret the accountants statuments for me. . . It is the accountant's task to interpret business operations for the bonsfit of those who havo a logitinato interast in thom (that is practicaliy overybody), in financial torins that practically everybody can understand $(58$, pp. 32-33).

\section{Other External Users}

ixtornal users of acoounting statements othor than invastors and potential invostors include craditors and prospuctivo croditors, social control agencies. amployoes, labor unions, and the goneral public. These staternent users may bo handicapped by the shortconings of accountine statoraents and the probloms involved in their uso which have already been discussed in connection with invostors. Most of these statement users do have an advantage orer investors in that most of thom do not have to roly entiraly on the published rinancial stataments. Craditors, potential creditors, and social control agencias may usually aslc for additional information as meoded. Labor unions have many other faotors to consider other than accounting statements.

These statement users would find inproved accountine statements userul. Thoir need is not as groat as the nood of investors for improved accounting statuments.

\section{Summary}

This chapter is tho first in a series of four chapters which discuss various measurement bases used 
in accountinz. Tho moasurement hasis discussed in the present cisepticr is histowlond co;t, thic ounc.pt micis is sresently usod in tizo groparation of acomunting statomints.

Several concopts rolated to thu historical cost concest heve bzen discussed. Muse concests also unterly accounting statemonts as tidey are curruntiy uropared. The realization concept iz particulariy relotod to the historical cust basis for measurament. The hirtorical divelopncat and the prescric status of this concept rave been disclissed.

$$
\text { Accounting statcracnts are used ly several }
$$

Erou, s: ranagcant, investors and prospcotivo investors, creditors end prospectivc creditors, social control agencies, ond labor urions. Shortcomings of accounting statcments have been pointcd out ir terms of those who use tl a stateronts. A dual goal of eccounting is sugEasted by the discussion:

1. Accounting statamants should bo more useful to those who understand accounting.

2. Accounting statoments should be useful to thoso wino have very little knowiedse of accountins. An alteriative to the socond poal is that accountinj statemsents should be prepared in such a manner that statcaunt reader 3 who have little or no knowlodge of accuunting w111 realize they aro not capabio of atilizing tho statenents. 
The following chreo chapters offer alternatives to the historical cost measurement basis. Lach of the three altornatives offered is discussed and compared with historical cost and the othor two alternatives. 


\section{CHAPER IV}

\section{CURIRENT COST}

\section{Introduction}

Historical cost, the measurement basis commonly used in accountind today, has evrtain advantages and disacivantages which have been discussed in the precoding chapter. Alternatives to the historical cost concept are discussed in this and the following two chaptors. These alternatives are current cost, net reailiabo value, and discounted cash flow.

The current cost concept is the topic of the present chapter. Current cost is the term chuson to include many variations of market value and replacement cost. Several of these variations are discussed and classifiod into two types:

1. Variations which separate income into

a. Holding gains and losses, and

b. Uperating incomo, and

2. Variations which recognize income on a production basis.

The sucond typo night also distinguish holding gains and losses rrum other income. These two types of 
concepts will be compared on the basis of usefulnesa, objectivity, and feastbility.

The current cost concept will be compared with historical cost on the basts of the criteria suegested in Chapter II: relevance (usefulness), objectivity. and foasibility. Quantiriability will not be discussed as this is a characteristic of both measurement methods.

\section{Income}

A major difference between econouic concepts of income and accounting concepts of income is a matter of timing. When should income be recognized? or when should an increment in value be recognized? This is also the major difference between various accounting concepts.

Income is sometimes thought or as an increment in value due to above-average decision-making ability or as a payment for risk taking. This can logicaliy be dofined as wages instead of income; incoure is then defined as an unexpected increment in value. Income as used in this study means both unexpected increments in value (pure profit) and incremonts due to aboveaverage decision-making ability and risk taking. Accounting income also includes interest on capital. Income is not necessarily recognized when it arises, that is, when an increase in value takes place. Determination of when an increment in value takes place should be of at least some value in determining when 
to racognize such an increiuent. for this purpose, tho business process may te divided into its components: purchasing, production, holciing, and seliing. Increments in value may take place due to any one ur all of theso activities. In current practice, no atterapt is usually made to determine when an increment takes place, and the entire income is recosniged in connection with the selline process as was pointed out in Chapter III in the discussion of the historical cost. measurement basis. such income includes incone due to above-arerage decision-inaking ability, risk taking, pure profit, and liplicit interest.

The nere act of purchasing does not ereate a value increment acoording to current accounting procedure. The increment dus to production is ustially measured in terms of the histortc cost of the ingredients addad. If the use of inanpower, the use of nanapemont, and tive use of land and capital in the form of current types of capital and oporating facilities are combined to form a product or service, the book value of that product is the combined total of the cost of the ingredients. The measurement of the cost of the ingredients inay be difricult to determine and may require soine use of ostirates. Usually, no efrort is made to determine whother or not an inorease in value takes placo due to holding an asset over a period of time. 
It is possiblo for lncranents in value to ta're place in asch of thaso activitias: purchasingo production, holding, and solllire. Alteriatires to current practice even suggest the recognition of such increinonts at the tine the ectivity takes place. It has been sugested in Chapter IIf that profit is due to the entire business process. Thus, the net realizable value concept would give recognition to any increment in value durine an accourtinf; period, regardless of which activity gave riso to such increments. A distinction might or might not necessarily be made betwuen the increments arising from the various activitius. This will be discussed in more detail in Chapter $V$.

Curront cost concepts vary. but they are desiened to measure separately income rrom production and selling or income from holding and selling. This chapter inciudes a discussion of this point.

\section{Price-1evel Adjustment Assumption \\ In this chapter on current cost it is assumed} that appropriate adjustments will be made for changes in the general price level as well as changes in individual prices. This is necessary in order ror the capital accounts to reflect the same amount of purchasing power.

The concept of purchasing power attains its validity frou the accounting objective to distinguish between investocl capital and income. Income results only if a person or firm is better of at the enci of a period than he or it was at 
the beginning of that period. Capital must be maintained in terms of its purchasing power for a firm to be as woll off at the end of the period as it was at the beginning (59. p. 434).

The invesinent purchasing power of the rilria can bo viewod rrom at least three different levels. (1) It may bo assuined that capital naintenanco applies to tine ability of tire riria to reinvest in an equai guantity of investment goods in general. (2) A second assusaption is that the firm will usualiy invest in capital goods of the samo industry and it is this purchasing powor that should be raintained. (3) A third assuaption is that the firm will usually purchase investment goods sinilar to what it has acquirel in tha past; each fira has a uaique invostmont and rolnvestment pattern that would servo as tho basis rur tiro computation of a firm purchasing power index (59.

It is this first concept of purchasing power which is assumed in this chapter.

\section{Variations of the Current Cost Concept}

Current cost concepts aro intended to ineasure changes in the specific prices as contrastod with general price-ievol changes. Reflection in rinangial statoments of specific prico changos is not a now idea. The following quote is takon from W. A. Paton's Accountinj Theory which was published in 1922:

It is abovo all important that the accountant's statoments present as accurately as posibib a picture of current data in terins of tixe actual dollar as of the diate of the statements. And this is not a matter of general price auvements-which may bo said to express the fluctuations in the significanco of money--but of spucirie prioe and value changes (38, p. 429). 
idwards and BoL1's Concept

Unc of the rocent discussions of current cost

is the book. The Theory and Measurement of Businoss

Incoine, by Sdgar 0. Edwards and Phl1ip W. Bo11. Many or tho ldeas are drawn from other sources; some of the theory is original.

cduards and Be11 present the thasis that "It is in the evaluation of business decisions . . that the derand for accounting data exists" (32, p. 3). Their goal is to arrive at methods of measurement which are useful in the evaluation of business decisions. Two measuroment concepts are eventually suggosted, and one of there is chosen as the better of the two. sdwards and Bell are prinarily concerned with the use of accounting rata by managoment. In general terins, they enuaerate the uses rade by manageaent of acounting. Accounting, through comparisun of actual erents whth expeoted events, ontributes:

1. to the control of current events in the production process.

2. to the rormulation of better decisions in the futuro, and

3. to tho inndiflcation of the dectsion-making process itself $(32, p .4)$.

Although the emphasis of the book is upon the uso of accountine data by management, the same data is userul for external purposes. External users are also interested in evaluation--the evaluation of management. 
The saine measurement concepts sugfested for managenent are al so suggested for most external users. sarly in the development of their theory, the authors put forth the premise that "in order to describe camplotely and truthfully with present accounting techniques the current position of a firm and its profit as it accrues, recorded costs must be equal to market values" (32, p. S). Knowledge of the current position of the firm is necessary in the evaluation of decisions. The problem is to find a workable measure of market value. What is market value? Edwards and Bel1 suggest more than one possible market value. Value may vary as to the rorm of asset, date of prico, and type of market. The rorm or asset may be initial, present, or ultimate. The date of price may be past, current, or ruture. The type of market may be either entry or exit. This fives a total of eighteen possible values. Table 3 is their presentation of these eighteen values of which the six underlined concepts are the ones the authors consider significant (32, p. 77). The authors are responsible ror the names of the concepts. Gurrent practice uses largely historio costs as the basis of valuation. profits are the difference betwoen curront values and historic costs, and, according to the roalization concept, are not recorded until a sale is made. Thus, past ontry values of initial inputs dominate the accounting records. 
TABLIS 3

AN ARRAY OF VALUE CUNCEPTS

\begin{tabular}{|c|c|c|c|}
\hline $\begin{array}{l}\text { Form a } \\
\text { value } \\
\text { date. } \\
\text { market }\end{array}$ & $\begin{array}{l}\text { Initial } \\
\text { inputs }\end{array}$ & $\begin{array}{l}\text { Present } \\
\text { form }\end{array}$ & $\begin{array}{l}\text { Ultimate } \\
\text { form }\end{array}$ \\
\hline Past, entry & $\frac{\text { historic }}{\text { costs }}$ & $\begin{array}{l}\text { discarded } \\
\text { alternatives }\end{array}$ & i r relevant \\
\hline Past, exit & $\begin{array}{l}\text { discarded } \\
\text { alternatives }\end{array}$ & $\begin{array}{l}\text { discarded } \\
\text { alternatives }\end{array}$ & irrelovant \\
\hline $\begin{array}{l}\text { Current, } \\
\text { entry }\end{array}$ & $\frac{\text { current }}{\text { costs }}$ & $\frac{\text { present }}{\text { costs }}$ & Irrelevant \\
\hline $\begin{array}{l}\text { Current. } \\
\text { exit }\end{array}$ & irrelevant & opportunity & $\frac{\text { current }}{\text { values }}$ \\
\hline $\begin{array}{l}\text { Future, } \\
\text { entry }\end{array}$ & $\begin{array}{l}\text { possiblo } \\
\text { replacement } \\
\text { costs }\end{array}$ & $\begin{array}{l}\text { possible } \\
\text { replacement } \\
\text { costs }\end{array}$ & 1rrelevant \\
\hline $\begin{array}{l}\text { Future. } \\
\text { exit }\end{array}$ & Irrelevant & $\begin{array}{l}\text { possible } \\
\text { selling } \\
\text { values }\end{array}$ & $\frac{\text { expected }}{\text { values }}$ \\
\hline
\end{tabular}

The two measurement concopts presented are reallzable profit and business profit. Realizable profit is composed of realizable operatinz profit and realizable capital gains.

Realizable operating profit is the incroase In Bdwards and Be11's opportunity cost due to production. Opportunity costs are defined by Edward; and Bell as "values that could currently be rallzed if assets (whother finished goods, semifinished goods. 
or raw materials) were sold (without further processing) outside the rirm at the bost prices immediately obtainable" (32, p. 79). Realizable operatint prorit is determined by substracting the opportunity cost or assets prior to production from tho opportunity cost after production. Realizable operating profit is the increment in value due to production only. No profit is attributable to change in valuation method. Realizable capital gains are the gains due to the increase in opportunity cost over time. Such gains aro coinputed by substracting the opportunity costs of assuts at the beginning of a holding period from that at the ond of the period. idwards and Hell have dividod time into holding perlods and production periods for simplicity. In actual practice, this cannot bo done. Tho same results can be obtained by determining the increase in speciric prices over a period of time if no change took place in production.

\section{Realizable profit is, then, the difference} between opportunity costs at the beginning of a period and opportunity costs at the end of the period. Healizable profit is due to a change in value due to production and a change in valuo ovor time. "The opportunity cost basis for record-keeping has this unique characteristic: except for the initial acquisition of inputs, all gains and losses can bo attributed eithor to changes in form or to changes in date 
and none can bo attributed to changes in the rethod or valuation itse1r" (32, p. 88).

The uso of opportuntty cost in the realizable profit concopt involves an oddity when work-in-process is concomed. Work-in-process is usually considered to b3 vorth at loast the total of the inputs. But this is not necossarily truo. Moonitz says that it is not usually true:

In the usual case, work in procoss and rinished coods are assuned to be worth more than raw mate$r i a l s$ by the amount of 1 sbor and other productive costs added; this is a rational attitude if the inventories will be disposed of in the normal course of business of a going concern. As others have pointed out, however, the imnediate market (1iquidation) value or work in process is usuajiy low compared with the market valuo of the materials berore processing (31, p. 40$)$.

Moonitz illustrates this with an ezample of printed pages of \& book. The work-in-process (printed pages before they are bound tocether into a book) are worth less than the paper used. The printed pares are almost worthless to anyone other than the firm froducing the book. It would seem that Moonitz would not agree with the use of Edwards and Bell's opportunity cost as a logical and userul basis for mosurement of work-in-process.

Opportunity cost may be as grast as net realizable value, especially in the case of finishad poods. opportunity cost seldom exceeds not realizable valuo. Such a situation would usually indicato that the rirm 
should sell the goods immediately instoad of carrying such goods through anticipated channels.

Edwards and Be11 classify realizable profit as a short-run concept of profit:

If this gain. which includes both operating profit and capital gains, exceeds interest on the opportunity cost of the $f \mathrm{mn}^{\prime} \mathrm{s}$ assets at the beginning of the period, the owners were wise to permit the business to operate during the period rather than discontinuing it at the beginning of the period. The existonce of a gain informs the owners and others that the shortrun cost of operating the business has been covered (32, p. 98).

This short-run concept, operating profit, indicates whether the firm should use the particular asset or set of assets rather than 1fquidate. The authors belleve it indicates very $11 \mathrm{t}$ le about whether or not the production process is worth extending beyond the 11 fe of the particular asset or assets (32, pp. 100-1). The second measurement concept suggested by sdwards and Bell is called business prorit. Business profit is composed of curront operating profit and realizablo cost savings.

Current operating profit, ono of the components or business prorit, is computed by substracting current cost before somo production takes place rrom current value after the production takes place. Current value and current cost are two of the oighteen value concepts 1isted in Table 3. Current cost is an entry value; current valuo is an exit value. Current oost is definod as "the cost currentiy or acquiring the inputs which 
the firm used to produce the assets bein valued" (32. p. 79). Current values are derined as "values actually realized during the current period for eoors or services sold" (32, p. 79).

Reallabble cost savings are the increases in current costs over time. Realizable cost savinfs for a given period are computed by substracting the current costs at the beginnin; of a period from the current costs at tho end of tho period.

Business profit includes, then, realized profits on a production basis and realizable profit on a time basis. Realized is used by the authors to refer to profits measured by an external transaction such as a sale.

Qdwards and Bell break down the realization principle into two parts: production basis and time basis. Table 4 indicates the differenoes in the makeup of accounting profit and the authors' business prorit and realizable profit. The table indicates that business profit is much noaror to accountin? profit than realizable profit is. The difference botwoen accounting prorit and business profit is the way in which increases in value (specific prices) over time are handled. (This is not meant to imply that the difference is small or instgnificant.)

The business profit concept abandons the realization principle on a timo basis. "When the realization 
principle is abandoned in both of its dimensions, we have a concept of profit based on opportunity cost, a concept wo have termed realizable profit" (32, p. 274).

\section{TABLE 4}

A COMPARISON OF REALIZATION AND REALIZABLE CRITBRIA

Entry values
(realization
principle:
production
basis)

Historic values

(realization principle:

time basis)

Current values

(realizablo principle:

timo basis) acoounting
profit

business

prorit
Exit values

(realizable

principle:

production

basis)

¿dwards and Bel1 consider business prorit thoir long-run concopt of profit as opposed to realizable profit, their short-run concept. They feel that business prorit is not only more userul to internal users but also more useful to external users than realizable profit. Howover, since each profit concept serves a different purpose, the ideal situation would be the incorporation of both concopts in the accounting records. The accounts could bo made riexible enough to accomplish this. If the accounting records are to include only one of these two concepts, idwards 
and Bell would choose business profit as boing the more userul or the two.

A seperate adjustment ror increases in the general price level is assurad in both the realizable prorit and the businass profit concepts.

\section{Sprouse and Moonitz's Concept}

In Accounting Research Study Number 3 entitled "A Tentative Set or Broad Accounting Principles for Business Enterprises." Robert T. Sprouse and Maurice Moonitz emphasize a current cost concept. They 11 st three exchange prices which may be used for pricing (valuing) assets.

a. A past exchange price, e.g.. acquisition cost or other initial basis. When this basis is used, proftt or loss, if any, on the asset being priced will not be rocognized until sale or other transfer out of the business entity.

b. A current exchange price, e.g.. replacamant cost. When this basis is used. profit or loss on the asset being priced will be recognized in two stages. The first stago will recognize part of the gain or loss in the poriod or periods from time of acquisition to time of usage or other disposition: the second stage will recognize the remainder of the gain or loss at the time of sale or other transfer out of the entity, measured by the difference between sale (transfor) price and replaceinent cost. This method is stili a cost method; an asset priced on this basis is being treated as a cost ractor awaiting disposition.

c. A future exchange price, e.g., anticipated selling price. Whon this basis is used, profit or loss, if any, has already been recognized in the accounts. Any asset priced on this basis is, therefore, being treated as though it were a receivable. In that sale or othar transfer out of the business (including conversion into 
cash) will result in no gain or los s, except for any interest (discount) arising from the passage of time (2, pp. 23-24).

The serond price, current excluange price or raplacoment cost, is the price which is of particular concern in this chapter. And it is the price which Sprouse and Moonitz feel is of most significance. The third orico, future exchange price, is the preferrod method of measurement for most assets according to the authors. Because of tho lack of objectivity of future exchange prices, the authors feel that a current exchange price may be better for the measurement of assets such as inventorios, plant and oguipment, and land. Sprouse and Moonitz believo "measurement of inventories at not roaliable value is the proforred method ghenurer the measuremant is objectively doterminable" (2. p. 23). Replacement cost is the noxt best valuation for inventories, and it is the best one to 11 se when net realizable value cannot be objectively determined.

Replacement cost is not a self-explanatory term. The terr "replacement cost" has many meanings:

The term has been used to mean the anticipated cost of replacing an asset when it will be retired, tho current oost of replacement of a precisely siallar asset or building in the saine location. the cost to obtain an asset that will provide tho same sorvices as the existing asset, the curront value of the service provided by the existing asset or to be provided throughout the ramaining if by speciftc cost inderes (59, p. 487). 
Considering inventories first, raw materiafs

and other inventory items which require no processing seem least troublesome. Replacement cost would seem to be the cost of buying these iters in the usual quantities from the usual vendors at current pricos rather than the prices which were actually paid sometime in the past. Rererring to Table 3, this would be what Edwards and Bell call current costs. The meaning of the torm replacement cost is not quite as clear when work-in-process or rinished goods are involved. Do Sprouse and Moonitz mean the current cost of the initial inputs or the cost of replacement of the inventory item by purchase of the item in its prosent form? The former possibility would be the sano as Fdwards and Be11's current costs wh110 the latter possibility would be the same as their present costs. In general present costs would be larger than current costs. Present costs would ordinarily include not only the initial costs of the inputs but also the value of tho utility added to the inputs by the production process.

If present oosts are used in pricing work-inprocess and finished goods, this would usually result in recognizing some profit due to production berore an actual sale or delivery takes place. Sprouse and Moonitz do not seem to be reoommending this. They indicate several times that the use of a curront 
replacement cost would recopnize only holding gains and lossos until actual sale. This indicates that their current roplacement cost would be the same as Bdwards and Be1].' s current cost concept and not their prosent cost concept.

Sprouse and Moonitz's discussion of the measurement of assets indicates that their current replacement cost does not recognize revenue due to production. The explanation of replacement cost already quoted does not make this clear. It merely states that part of the pain or loss on an asset is recognized in one stage and part in another. The explanation does not label or oxplain what gain or loss is recomized in anch stage. In a later passage in which the authors aro pointinf out the advantages of the current replacement cost concept. they say: "The use of current (replacement) cost has the further advantage of introducing a clear-cut distinction in the accounts betwoen prorit from holding an item through a prioe rise or fall, and profit from 'operating margins.' that is, the difrerence between sales price and current (replacemont) cost of tho Boods sold" (2, p. 29). This clearly indicates that the use of current replacement costs would result in the recognition of holding gains and losses in orie stage and normal operating profit (increase in value due to production) in another stage. 
In setting out what they intended to say about recognition, the authors said. "We propose to use a classirication that distinguishes among (a) the amount attributable to changes in the do11ar (price-1evel changesi. (b) the amount attributabie to the acquisition of goods and services prior to their utilization. and (c) the amount attributable to sales in a current market" (2, P. 17). This obviously postpones recognition or changes in utility due to the production prucess until final sale.

So rar, It seems quite clear what Sprouse and Moonitz mean by current replacement cost. It seams to mean the same thing as Edwards and Be11's current costs concept; that is, the current entry cost of initial inputs. However, a later comment by jorouse and Moonitz confuses the concept. In comparing their concept with curront procedure, they say. "By the use or current replacement cost, a change in 'utility' is recognized in the poriod when the change takes place" (2. p. 31). The word "ut111ty" is perhaps a poor terin. Up to this point in their discussion, the authors had indicated tinat the use of a surrent roplacement cost would give rise to a holding gain or loss: that is, the change in the specific price of the asset would be recognized. A change in the specific prico of an asset may be thought of as a change in the utility of that assot. This concept would consider utility as 
a relative torin-reiative to the utility of other assets. "Chauro:s in utlity" usually indicatos a different concopt-mat chan o in the abjoluie usorulnoss of an asset, and that is the purpose of most business entorprises--to increase utility. A manufacturor crat:s utility by bringing tojeth:r luputs in som rashion. Wholesalers and retaliers create utility by brin, in soods together in time and place. If Sprouse and Moonitz are using utility in this latter, more comon, meanine, they are contradictin: what they have alreacly said and are recommendinf the recosnition of reverue on a production tasis. This viter believes tho autrors interidui the former meanin of utility and have merely used a poorly chosen lern.

Sprouse and Hoonitz mak another clailu for their curront cost concept which is not quite what it appears to be. Thoy say:

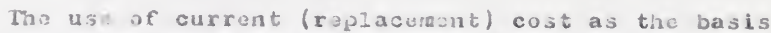
for inventory measurement elininates the need for any assunation a.s to the flow or actual cost incurred. The current cost of inventories is the sanc whoticer th: relatid undorly ing records and tax returns aro based on an assumption or a lastin, first-out $f$ low of actual costis incurrod, a first-in, first-out rlow, a weighted average, or spocirle ilantifleation (2, p. 29).

The flrit sentence soens to lmply thero is no nocd for a cost-rlow assunption. The second sencence shows that lihis is not true at all becauje such an assuastion is noodel for tax returias. Mro assumption 
must be made and the recoris must be kept at lonst ror tax returns.

Liven if the tax problom is ignored, an assumption still seems necessary to show the realized and unrealized elements of profit. As Sprouse and Moonitz have vory jittle to say concerning the distinction between realized and unraalized profits, thoy apparontly do not feol the distinction is very significant except for certain uses of accounting. The rollowing statement is ono of their few comments concerning: unroalized elements of gain in connection with inventories:

The amount of the "unrealizud" element is of significance in connection with income taxes and may be with respect to the legal aspects of dividend policy. The disclosure of this amount is readily accomplished by reporting the extent and the errect of the adjustment made to beginning and ending inventories (2, P. 30).

If a distinction is to be made for any reason between realized and unroalized elements of profit, then an assumption as to the oost rlow of inventories must be made and appropriato underlying records must be kept.

Sprouse and Moonitz also recommend the use of current cost for plent and equipment. Net realizable velue does not seen applicable:

Thoy do not represent potential revenues, as do the inventories, and thererore are not amenable to trotinent as though thoy were recelvables. As a consequence "net realirable value" has no relovance, except as a measure of scrap or secondhand value... (2, p. 33). 
The elimination of net realizable value as a possible valuation concept leaves a cholce between past cost and current cost. Sprouse and Moonitz choose current costs:

In the external reports, plant and equipment should be restated in terms of current roplacement costs whenever somo significant event occurs, such as a roorganization of the business entity or its merger with another entity or when it becomes a subsidiary of a parent company. Even in the absence of a significant ovent, the accounts could be restated at periodic intervals, perhaps every $r i v e$ years $(2, p, 34)$.

Such use of current replacement costs would give rise to holding gains and losses.

Accounting Research Study Number 3 is not intended to be a detailed set of rules. This is especially noticeable in the discussion concerning plant and equipmont. Thoir discussion is obviously a general one. Questions such as how to arrive at current replacement costs are not discussed. The authors merely mention the possibility of using index numbers and leave further discussion for others.

In another source Sprouse emphasizes the need for current values. He belleves that "if rinancial reports are to provide relevant information concerning a corporation whose shares of stock and other socurities are continuously changing hands and whoso economic Iffo is viewed as inderinito, attention unst be focused upon the objective (that is. Impartial) measurement of wealth and changes in woalth at the time such changes occur" (60. P. 688$)$. 
"The failure to report a measurable gain merely because it has not yet beon transformed into cash is not impartial; it represents consclous bias in favor of prospective croditors and investors" (60, p. 692). Sprouse feols that accounting should provide information which is relevant for making decisions. Here again. Spro:sso is recomanding the use of current market values and replacement costs.

Other Current Cost Concepts Accretion.-- The accretion concept may be thought of as a current cost concept. The accretion concept defines income as "an increase in econoric power which can be measured with reasonable objectivity" (61. p. 14).

Lidward Phillips gives the following list of income concepts to show how the accretion concept compares with other concepts as to objectivity:

1. Psychis income

2. ticonomic present value income

3. Accretion income

4. Accrual accounting income

5. Cash basis accounting income

"Accretion recognizos income if the increase in value is reasonably measurable: $0.8 .$. rerlected in increased market value" (61, p. 17).

Phl11ips believes cunceptual reasonableness is sacrificed for objectivity as you go down the list. 
"The case ror the accrotion concept rests on the proposition that maricet values are sufficiently more objective than comsuted prosent values to justify their use despita the lass of coneeptual soundness and that the further gain in objoctivity doos not justiry waiting ror 'realization' as presently derined" (61, p. 17). "icononic present value income" is similar, if not the same as discounted cash flow.

Under the aceretion concept, expenses as wel1

as revenues are resognized when "reasonably measurable." This, not the matching concept, determines timing of expensos and revenuss.

Horngren's proposal.--Charles T. Hornigren proposes a current cost concept which includes a liboral recognition test and a strict raalization test. The rules for realization include recognition as the first of three ruies:

1. Mecognition--Sufricientiy definite, verifiable evidence to permit objective moasurement of a value increase.

2. Market transaction--An event "originated by the voluntary interaction between the accounting unit and somo other unit" 162 , quoted from 63. p. 14).

3. Gonds or services rendered--The "removal of restrictions against assets" (62. quoted fron 64. 2. 32 ).

Thus, revonue may be recopnized without real1zation taklng place. Revenue recopnized would include "(a) holding gains related to assets still on hand 
plus (b) gains attributable to current oxchange transactions" (62, p. 326).

Thus, Horngren's concept of racognition would not inciude an increase in value rue to protuction. Valuations used in determining tho amount of revenue to be recognized would probably be the current cost of inputs.

Horngren's concept is a compromise plan aimed at reconciling the two extreme sides to income reporting :

The trouble is that practicing, accountants sometimes adhere too stubbornly to orifinal expectations as being overriding. While their critics lean toward measuring happenings as early as possible without worrying about (a) some loss of objectivity, or (b) how the decision finaliy turns out as a whole. in light of original expectations, and (c) the financial and tax implications of their net income ineasure (62, p. 328).

Horngren recominends this combination of recognition and realization. This would involve the use of two income concepts presented simultaneously.

AAA Committee.--In 1964 the American Accounting Association Domnittee on Concepts and Standards-Inventory Measurement recommended replacement cost for the valuation of inventory items. This recommendation was in the form of "Supplementary statement No. 2 " to the 1957 revision of "Accounting and Reporting Standards for Corporate rinencial statements" (65).

Their replacement cost concept for inventories would separate holding gains and lossos from operating 
revenues and expenses. Replacement cost would involve for a manufacturer the "current (replacement) cost or each elemont of the total oost of the inventory units" (65. p. 710).

The cormititoe did not agree on whother or not holding gains and losses should be considerad as realized. Three mombers of the committee (Firmin. Hepworth, and Wixon) believe that replacement cost evidence is "surficiently definite and objective" to regard holding gains and losses as realized. The other threo mombers (Ilorngren, Mautz, and Zlatkovich) believo that both holding gains and 10 sses should be regarded as unrealized unt1l the goods to which they relate are sold (65, p. 709).

The Most Desirable of the Current Cost Concepts

The previous section is largely composed of a discussion of various current cost coneepts. This is not intendod as a comploto list of concepts becauso the possible variations are great. These concepts discussed are thought to be representative.

These concepts may be classiried as to those which soparate increase in value into operating income and holding galns and those which recognize fincreases In value due to production. 


\section{Holding gains and losses}

Some of the current cost concopts discussed in tho previous section roport holding gains and losses. Such holding gains and losses are recognized as they arise. All other increases in value are not rocognized until a sale for other currentiy accepted basis for recognition) takes place. This amounts to rocozniring incroases in the value of inputs as such increases in value take place due to the holding activity of the onterprise, but it does not rocognize inoreases in value due to any other of the business activities until the rinal salo takes place. The reporting of holding gains and losses separately from revenues and oxpenses due to regular operations can be useful in ovaluating business performance.

\section{Supposedly, all. rovenues and exponses other} than holding gains and losses are due to the operations of the business. On the other hand, holding gains and losses may not be as simple. They cannot bo assumed to always bo purely a matter of luck as thore may be planning involved. Management may foreseo a riso in the price of certain inventory itoms and purchase quantities large enough to create a holding gain. Or. as a result of poor planning, management may have overstocked certain inventory itoms while racing roreseeable price declines of those particular items. Such gains and losses are due to the actions or lack of 
actions of manajouesnt; thoy aro not just a mattor of luck. Holding galns and losses may result from decisions by manegement.

There are definite advantages of separating holding foins and losses rrom operating income. Ir they are not reuovod, then income may include not only the opcrating income but also holding Eains and losses of the current porlod and past porlods applicable to assets sold or used up durinis tha current period. If holding gains and losses are separated from operating proftt each period, then the changes in valuo due to holding activitios for the given periad are known soparately from such changos in value during othor periods. The operating profit is known and can usually be attributable to management and not just luck. Un the other hand, if. Bdward lhlips suggests that the separation of holding gains and losses from other rovenuo and exponso serves little purpose:

All business activity is directly or indirectiy related to the production of goods and services, and it is impossible logically to split of gains and losses as being unrelated to such production. So-callod procuctive operations are continually affected in a myriad of ways by things outside the control of management. Thus it is also impossible to distineuish revenues and expenses as those things over which maneeement has control (66, ). 703$)$.

squality of gains and lossas

As has previously been pointed out, this chapter assumes adjustments for changes in the general 
price level. Changes in the general price level result from changes in individual prices. If al1 individual prices change at the same rate, an adjustment for changes in the general price level would be the only adjustment needed. Current cost concepts which result in the separation of holding gains and losses from operating income would be unnecessary because such gains and losses would not exist.

Since specific prices do not vary at the same rate, then holding gains and losses do exist. On the average, as many specific prices will be below the general price level as will be above 1t. Therefore. for the ontire group of goods used in computing the general price-level change, the total holding losses w11 equal the holding gains. For an economy as a whole. holding losses will be equal to holding galns. Al though all holding gains and losses cannot be attributable to luck and all other pains and losses attributable to the errectiveness of manageinent, this writer foels there is much value in such a separation. This gives a starting point for an analysis of how profit came about. Holding gains and losses are a matter of luck to the extent that price changes cannot be predicted; other income is usually due to the effectiveness or management. Holding gains and losses are attributable to the correct periods, and this is an aid in evaluating results. 
Production Income

Some current cost concepts would result in the recognition of production income--that increase in utility due to production--before an actual sale takes plaoe. The accretion concept and the realizable profit (opportunity costs) concept discussed previously are exainples.

The production process adds utility to a product. Production is here used to refer to all activities needod to create joods and services, other than holding activities, and not just to the physical combination of materials or workin with materials. If the production process is successful, a product is produced which has economic value ;reater than the inputs.

Reed K. Storey has the following to say about production:

This is true in both manufacturing and merchandising business. Both kinds or enterprise create utility since man cannot create material goods. He can merely rearrange and move goods so as to make them more serviceable. This is the service performed by both traders and manufacturers (67, p. 4.50).

Current cost concepts which recominend the recognition of the increment in value attributable to production seem to be fewer in number than those current cost concepts which emphasize the recognition of holding gains and lossos. lidwards and Hell present two current cost concepts but select the ono which 
omphasizes the holding gains and losses. Their opportunity cost, or roalizable profit, concept is considered the less usorul of the two concepts.

A tentative conclusion is that a current cost concept which ompliasizes the distinction betwoen operatin profits and holding, ains and losses but does not recognize production incorae until the tine of sale would efther be the most casily neasured concopt or would be the most useful current cost concept. The prevalence of such concepts in accountin; ifteraturo sould indicate this. Edwards and Soll reached the conclusion that it would be most desirable.

But why would this be txue? Why would this typo of current cost concept be most desirable? Criteria susEested at the end of Chapter II will be used here. Ono possibility is thet this concept is more reasible because it is closer to current practice than a concept which would recognize production income. This would create a loss radical change and would perhaps be easior to unclerstand.

Another possibility is that a current cost concept which recoenizes proüction income is so close to a net realizable value concept that tho net realizable value concept might better be accepted rather than the current cost concept. A comparison of net realizable value concepts with curront cost concepts is inclused in tho following chapter. 
silil another possibility invoivos osjoctivity.

The difference botwoun the two classes of currant cost oucopts prosontos in this chaptor is in the recupnition of production invaide srlor to sale. Thus, the difforence invuives bise vaiuation of invantorios. Obtaining asasurenant of tia injutis contalad fil frvantories is likely to be aure objectivo than obtaining aoasuromont of an inventory iten just as ic is. Ia general, thero is a raady maxket for inputs; moasurament is readily availablo. In genaral, there is also a raady magket for tho final product; again, neasurement is readily available. But in between the two points--during production--a market ros tio proluet, in whatavor rorin it happens to have. nay not exist. Tho current cost of the inputs may be easier to doterinine (feasibility) and more objoctively detarinined.

The use of a current cost concept which recognizes increaents of value due to production doos not necessarily preolude the computation of trolding galns and losses. Such computation would require sore uneasure of replacement cost or laputs as well as a measure of tho value of itons in their present form. Thus, this type of chrrent cost corcept aould have the advancairos of both types. The difficulty and expenso oi fiudiug both weasures of value could coon that a soparation or kolding gains and losses rrom production incume on inventury itums still on hand may ba highly impractical. 
Omiting increments in value due to production on inventory items still on hand often proves to be feasible. For example, if approximately the same amount of inventory at the same stages of production is on hand at the ond of each period, then net income is the same for any given period whether inventory valuation includes the increment in value due to production or not. There will be a misstatement of value on the balance sheets, but the error is approximately the same on the beginning balance sheet as on the last, and the relevance (usefulness) of the statements is not materially affected.

If there is very 1ittle work-in-process or finished goods at the onds of the accounting periods. then omission of production income on such inventory items is of little significance.

Perhaps it is for these practical reasons that writers advocate current cost conoepts which emphasize holding gains and losses and not increments in value due to production. Current cost concepts which emphasire holding gains and losses do have the advantage of greater objectivity and feasibility than other current cost concepts. On the other hand. current cost concepts which measure income on a production basis have greater relevance because they result in a closer approximation to value and because holding gains and losses may be aeasured by these concepts also. 


\section{Comparison with the Historical}

\section{Cost Concopt}

The proceding section has been a discussion of the curront cost coneept-on variations of the current cost concopt. The preceling chapter was a discussion of the historical cost measurement basis with emphasis on the current realization concept. Tho

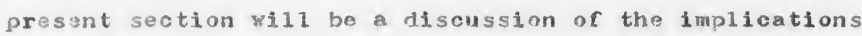
of tho current cost concept. These implications are brought out by comparing the current historical cost concept with the current cost concepts.

\section{Usefulness}

One of the criteria suggested at the end of Chapter II to be usod in comparing measuroment methods was userulness, or relovance. Is historical cost or current cost more relevant to those who use accounting data?

In Chapter $I$, It was assumed that al1 users of financial data wished to know financial position and results of operations. To the extent that economic value (the present value of future net cash flows) is an accurate (or more noarly accurate) indicator of rinancial position and income, then current cost is more relevant than historical cost. kiconomic utility. or expectod service potential, is perhaps the ideal measuroment of any assot. Valuation would then bo the expected ruture inflowing streams of oash. Market value 
(an indication of current cost) unay be thought of as a measure or these expected future receipts because market values represent the expectation which poople have of future receipts.

R. J. Chambers, an adruoate of current inforination, sees no usefulness in historical cost:

We therefore regard it as beyond question that the only information which is useful at a point of time, is infomation rolating to the financial position at that time. The conventional balance sheet is no more userul than last year's news with this year's dates superimposed (68, p. 271).

\section{Accounting Statements}

Statement readers ere accustomed to the financial statements currently prepared under the raalization concept. Shortcomings of those financial statements were pointed out in Chapter III. Despite these shortcomings, it is possible that many people can better understand tho statements as they are currently prepared than if statements were propared under a current cost concept. This would be especially true if certain complications in the accounting statements are found to be desirable or necessary. For exanple, gains and losses might be separated into real and fictional elements due to changes in the general price level. Also, it might be desirable to separate realized from unrealized profits and losses.

The smal1 businessman and the small invostor might rind current cost statements confusing as indicated in the following quote: 
Accounts are kept, profits are computed, and policy decisions are inade by several hundred thousand individual businessmen and their bookkeepers and elerks. Most of them would have grave difficulty in applying or even comprehending the principles of measuring cost exptrations in terms of hypothetical purchasing power. The economic data avaliable to them are certain to be inadequate and their interpretations of several dozon tables of price-inder numbers are likely to bo diverse to say the loast. Depreciation calculations contain enough elements or variation now; price-index adjustments would so magnify the inconsistencies as to render the conputations neaningless 13. p. 71. quoted rrom 69l.

Although Greer and Wilcox were talking here of general price-1evel adjustments, they would probably be just as concerned about ceneral and specific pricelevel adjustments. Complications in the acoounting statoinents in order to reflect current cost rathor than historical cost would perhaps of rset to some extent the increased usefulness which might be brought about by the use of current cost.

Un the other hand, accounting statements rail to tell the complete truth. As was pointed out in Chapter III, accounting statements may be inlsieading. This has been pointed out by able accountants such as Henry w. Swceney in his Stabilized Accounting and Kenneth MacNeal in his Truth in Accounting.

If the actual situation is complioated, it cannot be made less complicated by preparing uncomplicated statements. If the actual situation is complioated and if the current cost concopt rofiects tho actual situation buch bettor than the use of tho 
realization concept, then the current cost concept should be used even if tho resulting accounting statements are more compilcated.

Accounting, statoments usually present rinancial data of a complex business enterprise. If accounting statements were to be presented in terms simple enough for anyone to understand them, they might mislead a person into thinking that the financial affairs reflectod in the statements were also simple. At the end of the previous chapter it was suggested that accounting statements should elther be simple enough to be understood by a person with very 11ttle knowledge of accounting or be so complicated and technical that the reader would reallze his inability to use the statements. This discussion indicates the second would be the more desirable alternative.

Inventory valuation

Une of the main differences between the historical cost consept and a current cost concept is in the valuation of inventories. This valuation affects both the balance sheet and the income statement.

The first major current cost concept would result in inventories being increased or decreased due to holding trains and losses. The use of the second major current cost concept would result in inventories being increasud or decreased for all increments or 
decroments in valuo. As has proviously beer pointed out, there would bo no effoct upon net lucouo if beginning and ending invontorios under current cost difrered from their corrosponding inventories under historical cost by tho same amount. In all cases, however, the balance sheot reflects more accurate valuations under current costs.

other asset valuations

The application of the current cost coircept to othar assets results in the racognition of holding gains and losses and not production incone. Current cost concepts do not vary greatly except in the valuations of inventories. The use of a current cost concept for the valuation of assets means that valuos are inore meaningful.

If assets are valued at current costs, then the asset expirations reflected in the income statemant masure nore accurately the value of servicas randerod.

Unroalized income

The use of currogt costs rosults in tho recognition of rovenuo beforo such ralatod incouv is roalized in tho sense that "raalized" is usually usod. Some current cost concepts sugerest a distinction be made betwoen realizud and unrealized incoure. Juch a distinction would aid in bridglng the gap betwoen the use 
of the historical cost oncept and the use of current cost.

Dual accounting statements

The suggestion is often made that dual accounting statements be prepared. One set of statements would be prepared under traditional accounting and the other set under another method--in this case, current cost. This use of dual statements would emphasize the difference between the two concepts.

\section{Implications for cost accounting}

\section{Inventory flow assumption}

The accounting profession has faced the problems of inventory flow assumptions for several years without definite solutions. A variety of methods such as Lifo, Fifo, and average cost are considered acceptable. A change in revenue recognition concepts could afrect inventory rlow assumptions.

Current oost concepts could eliminate the need for any assumption about inventory flow, but this would not be possible if a distinction is made between realized and unrealized revenue. If such a distinction is made an inventory flow assumption is as applicable as ever. 
Abrorption costing vs. diruct costine controversy

The assumption in diroct costing is that inowo slumld vary with salesm-not with a combination of salos. Froduction, and changes in inventories. The cunflict betricen rull costing and direct costin, has becn goin on rox surar timc.

A change in concepts of reverue rocosnition would affoct this controversy. The adoption of a cost concept which gheasuros the value of an item in its present state would elfainate the direct cosing controversy aliojether. On the other hand, the adoption or a cost concupt such as replacement cost which adjustis only ror the current cost of the inputs rould have no efrect on the controversy at ail.

\section{viojectivity}

No matter how relevant the results of a given measuroment mothod may be, unless the results are objective (in the sense of verifiability and rreedom from blas), thoy are not acceptable in accountin. Usefuinass and objoctivity are orten thousht or as opposites. If one is given more weifht, tho other must be iven less. This is not mecessarily truc, for objectivity may contributo to usefulness. Paul is. Fertip exprosios this idea: "The purpose of beins 'objective' is to convince finanoial statement readers that statoments aro rree or ulterior motives or whim" (70, p. 139). The nore welght the statement reader 
can attach to stateraents, the more userul they may become to him.

The characteristic of objectivity may make accounting data more useful, but it does not follow that the greater the objectivity, the greater the userulness. For example, accounting statements prepared on the cash basis may be more objective than accounting statements prepared on an accrual basis. but accrual basis accounting statements are usually more useful. Accounting statements prepared under either basis aro considered surficiently objective. Likewise, historical cost is more objective than current cost. But does current cost have sufricient objectivity?

Accountants have traditionaliy used acquisition cost because of the difficulty of measuring objectively oconomic valuo. Also, historical cost is an objective measure of economic value on the date of acquisition.

In other words, when assets are intelilgently acquired, thoir expected servioes must bo equal to or greater than those available under acquisition al ternatives. Therefore, historical costs are a measure of expected service potential at date of acquisition (65, 0. 703).

William A. Paton has said that cost and value are "not opposing and mutual1y exolusive terms" (71. p. 193). Cost and value are assumed to be the same on the date an asset is acquired. 
In fact cost is significant primarily because it approximates falr value at date or acquisition. cost is not of basic importance because it represents an amount paid; it is important as a measure of the value of what is acquirod (71, p. 193).

\section{Subiective cost.--In contrast to the usual}

point of view, R. H. Homburger points out that actual costs are subjective:

The amount of the cost of an asset to any particular business is dependent not only on the time and place of acquisition. but on the judgment. hopes, fears, and preferences of the buyer as well as of the solier. While cost, as a measurement, is subjoctive with regard to those ractors. it is also objective to the degree and extent that cost refiects an existing narket price. This has led to the unavoliable guestion whether a measure based on current market value would not bo preferable to cost. if substantial differences exist between the two $(72$, pp. 96-97).

Homburger describes accounting measureront as social in nature, and therefore it contains a subjectivo element.

According, to this view, market values may be as objective as historical cost. If this is true. objectivity may be retained while increasing the usofulness of accounting statements. Lower of cost or market. - The lower of cost or market rule is an accepted rule of accounting ror tho valuation of certain assets. Market value is considerad objective enough for measurement purposes whon markot value is less than cost. Many accountants see an unsupported lack of consistency here. Should losses be recopnized when market values drop bolow costs while gains are not rocognized when market values 
rise above gosts? Paton says that "present valun is no less and no more sipniflcant to manayernont and all other parties conernod when such valuo happens to bo above recorded cost than when it is lower" (71, p. 137). However, Paton looks at the practical side of the issue and considers the problems of determinin: value, especially of specialized assets. For this reason Paton suggests that departure from cost should be considered "only where such a substantial and persisting change has occurred as to render accounting on the old basis inadequate and invalid in view of the recognized purposes or accounting" (71, p. 198$).$

The question of the objectivity of current cost is still unsettled; many writers believe it is sufriciently objective. Current costs of inventories may usually be more objectively determinsd than current costs of other assets. The question of the objectivity of current costs is one of the biggest drawbacks to the use of current costs.

\section{Feasibility}

Feasibility implies that the information is worth more than it cost. Current cost information does cost more than historical cost information; it is usually in addition to historioal cost information. Feasibility would depend upon which current cost variation is chosen, as some would be more difficult 
to utilize than others. Sorne variations such as sowards and BoLl's business profit would seem to be feasibie becauso they aro not too difficult to implement.

\section{Sumary}

The current cost concopts discussed in this chaptor have bocr classified according to whother they omphasizo holding gains and losses or whether they emphasize the recogaltion of produetion income as production taises place. Of the many vartations of current cost which have been suggosted by various writers, those which emphasize holding gains and losses predominate accounting iliterature.

if the two types of current cost concepts, the type which emphasizes holding gains and losses is more objective and reasible than the other type. Also, the soparation or holding gains and losses from other income $x$ sults in userul financial data as it gives some indication as to whether tho income is due to manazerial offort or fust chanco or the passage of Lime.

The tgpo of current cost concept which recognizes incuine as production takes plaos may be more useful. than tise othur type in that it is closer to economic incoino (incrasse in value). but this refinement of acountint is soldon considered worthwhile. 
liistorioal cost has been oumpred with current cost on the basis of relovance. ubjectivity, and foasibility. Current cost is more relovant to the uswal noods of uanagement and most external users because it results in firancial statements which nore nearly reflect firancial position and results of operations than does historical cost. On the othor hand, the difficulty reaciers ritht have in using current cost statements might diainish thoir userulnoss.

$$
\text { IIstorical cost is cortainly more objectivo }
$$

than current cost. However, the variations of current cost suggestad by some writers possess sufficient objectivity.

Historical cost is easier to obtain than ourrent cost, but some or the variations which have been suggested would make the use of current cost feasible. 


\section{CIIAPTISH V}

\section{NETT REALIZABLE VALUE}

\section{Introduction}

Chapter IV was a discussion of the use of current cost as an alternative to tho historical cost concept. The present chapter is a discussion of another possiblo alternative- net realizable value.

There are variations of the net realizable value concopt: soveral are discussed in this chapter. The net realizable value concept is compared with the realization concept and is also compared with the current cost concepts.

Rationale of Net Roalizablo Value

Net realizable value is usually intended to measure expoctod selling price discountod at a rate of interest and 1 ess cost to complete and sale. Thero aro other possible variations. Theoretically, the ooncept results in the moasuromont of valuo increinents as they occur. In order for the ooncopt to be practical, it is desirable to know how, why, and whon value incromants oceur.

Several theories of incomo were mentioned in Chapter IV. Incomo may bo duo to risk taking or 
unusual manajorial skill, but payments for risk taking and unusual managerlat skills (above averago decisionmakinp ability) inay be considered as earned by the factors of production. If payinents are not made to the appropriate ractors of production--owners and management--for these runctions of risk taking and unusual manageriai ski11, thon the residue after all ractors of production are paid will include increments in value due to these runctions. All such residue is considered to be income in this study. This will difrer from the concept of pure economic profit (due entirely to chance). Pure income, or profit, is also includod in the concept of profit used here.

Accounting profit also includes interest on the capital investod by the owners. This portion of prorit is particularly emphasized in the net roalizable value concept. In some variations of net realizable value the expected sales prices, and sometimes expected expenditures, are discounted back to the present to arrive at the present value by use of some rate of interest. Froin the present time until the time of sale the value of the asset gradually increases until. at the time of sale, the value is the sale price. The increase in value over $t i m e$ from the first valuation is due to interest. In conomic theory, this interest is attributable to a particular factor of production-capital. 
If accounting profit is derined to include value increments due to risk taking, unusual managerial ski13. pure profit, and the use of capital, then the next question is "then does profit arise?" In Chapter IV it was pointed out that profit is attributable to all of the processes of business: buying. holding. manufacturing, and selling;.

This sienificant problem in income determination hingos on revenue mezsurement and the metching of costs with revenues. The basic problen is moasurement. The historical cost concept, the current cost concepts, and tho net realizable value concepts are al1 concorned with the neasurement of revenue. The historical cost concept makes no attompt to distinguish between the value increment arising during the various phases of business activity. Current costs and net realizable value, on the other hand, do inake such an attenpt.

Holding gains and losses may be composed of interest as a payment for the use of capital and income as a payment for risk taking as well as pure profit (due entirely to chance). To the extent that managoinent is ablo to plan ror holding gains and losses then they are a payment for unusual management ski11s. Operating income due to buying. manufacturing. and selling, is attributable largely to unusual management skill. 
Golng Concern.--The net realizable value concopt ut111zes the going concern concept. According to Canning. going concern value means "the valuation should be dependent solely upon the contemplated use of the valuod thing in the operations of the enterprise" (73. p. 218$)$.

Instead of basing valuations on prices that now exist the net realizable value concept bases valuations on prices that are expected to be received when the goods are sold less expenses expected to bo incurred and less an appropriate amount for interest. Referring to inventory items, Canning says: "The present worth of the amount of money that can be got for them in the conditions in which the enterprise is placed, less the present worth of the ruture outlays and expenses properly rererablo to such a dollarvolume of trade expresses not merely the cisief but the only significance this existing stock of goods can have" (73, P. 219).

The usual situation is that a going concorn will plan toward the completion or goods. The situation may arise where the market value of a pood in process is greater than the net realizable value. If this situation is expected to continue, an entity may change its plans and begin selling the product when it reaches this certain stage of production. In general, such a situation is likely to be a temporary 
one, and an entity is unlikely to be in a position to change its production and seling plans temporarily in order to make a short-run gain.

For this reason, then, a $f i r m$ is more interested in the amount for which its rinished goods will se11 than the market value of a good at any given point in time. The main problem is in the difficulty of measurement. Market value may be more easily measured than solling price at some date in the future. When expected sale price is reduced by the cost of complotion and discounted at some rate of interest to arrivo at net realizable value, It is likely that market value is more easily deterinined, especially for raw materials and goods in process. As goods approach the time of sale, net roalizable value becomes easier to measure. Another application of going concern is also expressed by accountants. The view is taken that if an entity is expected to continue operations inderinitely, then net realizable value is not applicable. Gains and profits should be postponed until they can be expressud more objectively in subsequent periods. Gilman says: "Acceptance or the accounting poriod convention, and its subordinate convontion of the going business, introduced a new accounting concept, namely, that invontorying at realizable values was not appropriate for periodical reports, there being at the ond of each period a fictitious rather than 
an actual termination of the business unacoompanied by substantial chango of proprietorship" (74, p. 96). Those who use the going concern concept as an argument against not reolizable value may have a different concept of net realizable value than those who use the going concern concept as an argument for net realizable value. Inis first group may think of net roalizablo value as the not amount roalizable upon a forced or immediate liquidation.

\section{Variations of the Net Realizable value cuncopt}

In Ëoneral, net roalizable value nay be thought of as the expected selling prico loss expected expenses or completing and selling. There are many possible varintions of this concept.

Amorican Accounting Association

The Alaerican Accounting Association, in its Supplomentary Statement No. 2 to its 1957 statement. Gives several possible variations of the net roalizable value concept. Net reallzable value "assunes that all income or loss arises exclusively through the acquisition (purchasing or producing) activities of the business entity" (65, p. 706). The value of inventory is a measuremont of expected revenue loss expected costs of completion and disposal. All profit is attributabla to the buying or producing activity. and no profit is attributable to the other activitios. 
A slightly different concept is called "net realizablo value less normal operating income on activitios not performed," A normal oporating income is determined. The normal operating income on activities not performod may bo found by multiplying a somputed fration timos the cost of completion and disposal. The numeratox of tho fraction is the nommal operatins inoome, and tho denominator of the rraction is total costs including matorials, conversion, selling. and adrinistration. This is ono possible mothod of computing "normal oparating income on activities not performel." The main problom is to find a realistic mothod. A disadvantage of this method is that t?e liacome attributable to each activity is not nocessarily proportional to costs Incurred in that activity. "Any method of allocation has limited significance in the absence of arm's length market tosts at intermediato stages during the holding or converting process" (65, p. 707).

Still another version of net realizable value is callod "net realizable value less normal oporating incoms." This variation may be similar to historical cost. However, if replacement cost and selling prices move together, this variation gives results sinilar to the use of a current cost conoept which recognizes holding gains and losses. 
Tho Supplementary Statement No. 2 suggests the

use of roplacoment costs rather than net roalizable

value because of the difficulty of measuring the latter:

Many subjectivo estimatos aro required in its

implementation: expected revonio, expected

expenses, and allocation of margins between

acquisition and distribution functions. Further-

more, if sulling prices fluctuate in harnony

with replacement costs, the replacement cost method cenerally vill yield a rellable approximation of net realizable value less normal

operatine incono. Therefore, roplacement cost can generally meet conceptual and practical criteria more easily than can some version of net realizable value (65, p. 708).

\section{Jolun B. Canning}

John B. Canning suggosts that cost, market,

and net selling value be exhlbited simultaneously as each of them has a special significance (73, p. 221 ). Although Canning recogrizes several ways of determining the value of finished goods the mothod ho suggosts allows for selling and general oxpenses as we11 as a normal profit:

The one suggested here is to multiply each unit seli1ng price by a fixed constant, k. This constant is determined as follows. (1) Standard ratios to sales (preferably averages of the concern's own exporienco) should be found for loss on bad debts, selling expensos, and general expenses including costs of collection (but not interest paid or other distribution itoms like income taxos). (2) Some nomal industrial rate or return converted to an average rato on the concern's own inventories should be found. The constant whioh is to be multiplied into each selline price thon becomes one minus the sum of the rate allowances for subsequent exponses and for a normal profit on the inventory (73, p. 222). 
For raw unterials and unfinished goods, cost to complete must bo estimated and used in computing present value. $\Lambda$ s the aetual sale is further in tho futuro than is tho caso of finisiod goods, orrors in computing valus aro ifkely to bo greater.

This mothod is what the AAA Commitice called "net raalizabie value lass normal pperating income." Perhaps not 211 profits, but et least nomal profits, are postponor until the tims of sale.

\section{Sprouse and Moonitz}

Sprouse and Moonitz define assets as rollows: "Assets represent expected future economic benefits. rights to which have been acquired by the enterprise as a result of some current or past transaction" $(2$. p. 20). The value of an asset depends on the future economic benefits which are expected:

In other words, the problem of measuring (pricinis, valuing) an asset is the problem of measuring the ruture services, and involves at least throe stops:

1. A doterinination if future servicos do in ract exist. For examplo, a bujlding is capable of providing space for manufacturing activities.

2. An estimate of the quantity of services. For exemple, a building is estimated to be liseable for 20 more years. or for half of j.ts estimated total 1.ife.

3. The cholce of a method or basis or formula valuing the quantity of services arrived at under $\therefore$ nbovo (2. p. 23). 
At this point, the authors list the three

exchange prices which have already boen quoted: $\Lambda$

past exchange price, a current exchange price, or a future exchange price. This third choice is repeated here as it is of primary importanco in this chaptor:

A future exchange price, . g.. anticipated selling price. When this basis is used, profit or loss, if any. has alroady been recognized in the accounts. Any asset priced on this basis is, therefore, being treated as though it were a receivable, in that sale or other transfer out of the business (including conversion into cash) will rosult in no gain or loss, except for any interest (discount) arising from the passage of time $(2, p .24)$.

This future exchange price seems to be the most theoretically correct method of neasuring future benerits. There are ofton practical disadvantages such as lack of objootivo, verifiable data. For this reason Sprouse and Moonitz do not recomend the use of net realizable value for the measurement of all assots. Net realizable value could bo applied to receivables. Tho time until collection is usually so short that discounting is not of much value.

The application of thoir net realizable value concept to inventorios is more moaningrul. Tho authors foel that this concept should be applied "whenever the ultimate proceeds from sale can bo establisied" ( 2 , p. 27). "As a specific case in point, invontories which are readily salable at known prices with nogligible costs of disposal, or with known or readily predictable costs of disposal, should be measured at 
net realizable value (1.0.. anticlpated sales proceeds less costs of completion and disposal)" (2,p. 27). Sprouse and Moonitz's not roallzable value concopt would result in the recognition of revanue when an increase in value takes plac9--whother the increase ts due to an Incroase in the spaciflc prico level (holding gain) or due to an increaso in value as a result of production. The authors say it this way: "This procodure 1111 have the result of assigning most if not all of the change in resources and the related profit or loss to the period of production for other activity) when the actual efrort was made" (2, p. 27).

Although the concept is not always applicable. "measurement of Inventories at net realizable value is the proferred method whenever the measurement is objectively determinable $e^{n}$ (2, p. 28 ).

The authors do not believe their net realizable value concept is applicable to plant and equipment:

They do not represent potential revenues, as do tho inventories, and therefore are not amonable to troatment as though thoy wero receivables. As a consequence "net realizable value" has no relevance, oxcept as a measure of scrap or secondhand value (2, p. 33).

Sprouse and Moonitz do not go into enough detail. to explain fully how their concepts would be applied. For example, they note the desirability of separating gains (10sses) due to changes in the spooific 
price levels from revenue due to the production of goods or the rendering of services. Such a separation is automatio in their current cost concept. It is not automatic in their net realizable value concept.

The separation would be possible to obtain by measuring the net realizable value at different points in time. The change in net realizable value from the time inputs are acquired until they aro placod into production would be a measure of gain or loss due to changes in the speciric price levels. The change in net realizable value due to production would be a measure of profit due to production. Sprouse and Moonitz do not mention such a separation at all. Perhaps this is a detall thoy reel is not essential to their study.

This net realizable value concept is based on the assumption "that profit is attributable to the whole process of business activity, not just to the moment of sale" (2, p. 10). This ldea is not intended to be an original one with Sprouse and Moonitz. They quote the ldea fron accounting leaders of the past and present. One such quote is from George 0. May: "Uanifestly. when a laborious process of nanufacture and sale culminates in the delivery of the product at a profit, that profit is not attributable, except conventional1y, to the moment when the sale or delivery occured!" (75, p. 30, quoted in 2, pp. 10-11). 
Another such quote is from Villian A. Paton: "If there is a major point upon which there is general. agreoinent in accounting, it is that revenue results from the over-all process of production . ." 176. p. 39. quoted in 2, p. 11).

The preceding varietions of net realizable value emphasize the wide range of dtfferenses in the concept. Perhaps profjt is attributable to the entire process of business activity. but these variations range from a concept which results in no normal income realization until the time of sale, through concepts which result in some incone ratization throughout the business procosses, to a concept which results in the realization of all ineome imnediately upon the initial purchase.

The most logical variation of net realizable value secms to this writor to bo disoounted estimated salos price less disoounted estirnated ruture oxponditures roquiroi for completion and disposal and less profit allocated to incompleted aotivitios.

\section{Actual Use of Net Realizable Value}

The concept of net realizable value is not just theoretical at present; it is actually applied in some situations. The use of net realizable value is an oxception to the realization concept, but some applioations of net realizable value are accepted 
aocounting thoory according to both Accounting Research

Bulletin No. 43 and Accounting Rosearoh Study No. 3.

The rollowing quote is from Accounting Resecrch Study

No. 3:

It is Eenerally recoenizod that income accrues only at the tine of sale, and that gains may not bo anticipated by reflecting assets at their curront sales price. For certain artioles, howover, exceptions are pernissible. Inventories of gold and silver, when there is an effeotive Governmentcontrolled mariret at a rixed monetary value, are ordinarily reflected at selling prices. A similar treatment is not uncomion for inventories representing agricultural, mineral, and other products, units of which are interchangeable and have an imnediate marketability at çuoted prices and ror which appropriate costs may bo difficult to obtain. hrere such inventorios ere stated at sales prices, they should of course be reduced by expenditures to be incurred in disposel, and the use of such basis should be fully disclosed in the financial statements (2, p. 34).

According to currently accepted accounting procedure, "the ollccation of reventse to accountinf ferloc's in terns of production rather than sole is not an entirely unreosonable procedure if production is tho rain end of the enterprise, subsequent sale being aerely a routine incident, to be taken for granted (33, 2. :55).

Thore are also situations in wich nelther the currens cost concept nor the historical nost concopt applies. In such cases net realizable value may be tho logical measuroment concept. By products which do not have a raady barkot after soparation from the malo prodisct without furthor processing and for which historical cost cannot bo dotermined aro examples. 


\section{Contrast with the Mistorical}

\section{Cost Concert}

\section{Dbjactivity}

The histurieal dost cuncept is consilered to bo moro ojjoctive tha.a not realizable valus in most cases. Usw of tho curreat roallzatiun comongt lapiles that assots aro earrlod at cust oi adjugtod cojt until a salis talses 21ace. Cost is usua11y shjootively determined as it rosults from a lasrist transaction with an ontity ozternal tu tis onserpriso. Sinilarly, a salo gives an objoctivo basis for rovanus reoomitiua; asain, a arisot trassaotion intiz an onijity aztornal to tho eiterpriso usualiy tuises piaco.

Net roalfzable visluz, Ja tho otixor haud, loes nut rosult from an arm's length market transaction involving the ontappisu itsaif. Kuther, sot roalizable valuo is basad on transactions involviag tile utorprise which ars oxpocted to uccus in tho rutuso. Transactions which have already ocourrol will. In geaoral, result in valuations which ass uors objectivo thail valuations basad on ruture transactions.

\section{Prorit without a sale.-- Tho realization concept} depends wpon a $5 a 10$ as a basls for recugnizing revenue. for many accountants bellevo a sale is absolutely necessary. Their position can asily bo backod up by lilustrations. Obviously, no profit is made if salos are never made, regardiess of the areunt of production. 
Gilman presonts a few possibilities. "Recognition of income on tho basis of production could hardly fail to result in a most fantastic situation in the case of a new company organized to produce cash registers in competition with the National Cash Register Company, or adding machines in competition with Burroughs, or automobiles in compet1tion with Ford" (74, p. 122 ). In a row cases, net realizable value may be more objeotively determined than cost. This is why net realizable value is sometimes usod for valuation purposes.

\section{Userulness}

Although net realizable value is not as objective as valuations usod. with the roalization concept, this writer belicves the use of the net realizable value concept could often result in accounting rigures -loser to value. Some defree of objectivity micht well be sncrificed in order to more nearly approximate velue. Net roallzable velue would not be useful unless 1t could be measurod with a fair degree of accuracy. If net roalizable value is completoly subjective, most of its usefulness for oxtarnal acemating statements 1 s iost.

Net roalizablo value is here suggasted as a mure usoful measurement concept than original cost when orleinal cost does not olosoly resemble valug and net 
realizable value can be determined with only a small probable degree of error.

\section{Accounting statemonts}

For the assets to which net realizable value is applicable, a more useful valuation may be shown in the accounting statements than the valuation used with the realization concept--historical cost. This statement assumes a net realizable value with a reasonable degree of accuracy.

The use of the net realizable value concept on the income statement would have significantly different rosults rrom the use of the realization concept. Some revision of the income statement would be needed to reflect this concept. For example, an income statement might show the present value of estimated future receipts. Current expenditures and the present value of expected ruture expenditures would bo substracted from the revenue to arrive at net income. If it is desirable to divide net income between that which is realized and that which has not boen reallzed, other changes in the incomo statoment would be reçuired. The impact of the net realigable valuo oncept upon the balance sheet would also bo erate. It is likely that fower complications would arjse. hovever. Net realizable value does not soem appropriate for all assets. This moasurement basis seoms appropriate for inventorles, accounts roceivablo, and other 
current assots. Net realizable value is, in efrect, used for tize valuation of accounts receivable when an allowance for doubtrul acoounts is substractod frois tho total acounatis socoivable. Tho difforanco is the auouat wisich is expoctod to bo collectud. There is no allowance for discountinis at suno rato of intorust as this is vi $11 t$ te significanco.

the concopt is losi applioabio to otines asists such as plant, oquipront, and intangibio assots. Mese are assets used in the oporations of tho thinorprise and are not intonded to bo suld. Nonis of tise variations or not realizablo valuo suoms applicablo to these assets.

In triss writor's opinion, tine use of not radizable values which are reasonably aocurate in the acoounting statonouts, ospecially the incone statcraent, would result in statedants which are more userul than those statements which are propared under the realization concept. The increased usefuinoss rosuits from time cioser approximation to valuo.

The disadrantages aro much tro sano as those discussed in the provious chapter dealing with current cost. The main problem would probably be the lack of understanding on the part of statement readers. An approach to solving this problem would be the publication of dual statements--one prepared on the basis of the realization concept and the other on the basis or net realizable value. 
Teasibility

Thu feasibility of net realizable value as comparud with historical cost depends upon how difficult it is to det.rinine net realizable value and how userul it would b. Ihe unavoidable conciusion is that feasibility depends upon the circumstances. If net realizable value can be determined with a high degree of accuracy and without great cost, it is 1 ikely that tho increased usefulness would outweigh the additional cost.

\section{Contrast With the Current Cost Concept}

In contrasting the net realizable value concept with the current cost concept, it may be inappropriate to make genoral statements about which is more userul and which is more objective. Because of the possible variations of each concept, it is not possible to say that one is more objective and the other moro useful. As has been pointed out in Chapter IV, variations of current cost rall into two major classes. Since these two general conoepts of current cost are so differcnt, it is best to compare net realizablo value with each one separately. The comparison is Iimited to those assots to which net realizable value is applicable, such as inventories, accounts recoivable, investiants, and other current assots. 
Holding Gains and Losses

Net realizable value is first compared with the current cost ooncept which omphasizes the holding eains and losses. Comparison is difficult because of the possible rariations of each.

\section{Objectivity}

Current cost concepts which emphasize holding gains and losses give rise to substantially objeotive valuations. The curront prices of inputs inta a manufacturing process or merchandise held for sale by a merchandising enterprise may bo determined by consulting a vendor's current price list or a current invoice or by telephoning the vondor. There is usually an active market for such inputs or such merchandiso, so the current price may be considered objective.

The net realizable value of inventories is loss objective than the current cost of inventories. This seems to be true or the several variations of net realizable value. This is largely because the two major components of net realizable value--seling price and expenses to be incurrod--will be definitely determined in the future. isven though they may be predicted with a high degree of accuracy, they are by derinition less objective than valuations which currently exist. The nearer inventory items are to actual salo, the more objective is net realizable value. 
The curront cost of accounts receivabio is less meaningful than the current cost of inventories. Conceivally, the current cost of accounts recelvable nay be considered to bo the current cost of tho merchandise or servic. frou which the accounts receivablc resulted. Such a valuation would be an objective one, but it is not a very practical one, as the sale is usually considered an objective basis for the realization of income and valuation is increased by the amount of the income. The allowanco for doubtful accounts is intended to reflect the net value. and thus tho market value, of total accounts receivable. This market value would have iltte or no relation to the replacenent cost concept of current cost while net realizable value is applicablo.

The current cost of investments is an objective valuation if the trading of the security is active. If there is little or no trading activity, then the current cost, if one could be deternined, would probably not be objective.

The objectivity of net realizable value of investments depends upon the type of investinent. Not realizable valus of stock held as a lon;-term invosttaent is difficult to measure and not objeotive. Net realizable value of bonds is more objectively determined. The presence of, or lack of, a market value of 
investment is controling in detemaining wisic concept-net realizable value or current cost--is aore objective.

\section{Userulness}

If an accurate determination can be made or net realizable value, then net realizable value is a more userul concept to use in the rinanoial statements. Valuations arrived at by both conoepts could be shown in the balance sheet by giving additional information in parentheses or in the footnotes. The choice of methods is more important in the income statement. The use of this current cost concept results in the reporting of holding gains and losses along with income traditionally realized. idwards and Bel1 refer to this as eliminating the realization concept on a time basis but holding to it on a production basis. On the other hand, the use of net realizable value results in the reporting of all increases in value during a period of time as income of that period. Income under either concept might be divided into realized and unrealized elements. Incorae is realized when it passes the point of sale.

Net realizable value is more userul than current cost if net realizable value can be determined with a reasonable degree of accuracy for it is theoretically a better expression of value than current cost. 
Feasibility

Current cost is usuaily unch casier to detcraine than not rializable value and thorefore is more feasible. Net realizable value may result in a valuation which more closely aporoximates value.

\section{Production Income}

Net realizable value is now compared with the second major class of current costs which measures all increases in market value--not just the increases due to holding gains and losses. It is difricult to determine which is more objective for this would depend on the variation of each concept. The two concepts tend toward the same valuation. Market valuo of an asset is a sort of an averago ostiuate of not realizable value by all those who buy and sell that particular asset in the market.

A market may not exist for goods in process; an objcctive basis for tho valuation of the asset in a certain form may not bo present. Net realizable value may thus be more objective and more userul than this curront cost concept in certain situations.

In Genoral, comparison of the userulness, objectivity, and reasibility of net realizable value and this current cost concopt depends upon the variation or each. So ons Eeneral concept cannot be said to be better than the other. 


\section{Summary}

Net realizable value is another alternative to the historical cost conoept. Thoro are many variations of net realizable value. One comnon variation is expected selling price less costs of completion and sale. Another comon variation is the same excopt that both the selling price and future cost are discounted back to the present at some appropriate rate of interest. The concept chosen as most logical is discounted estimated sales price less discounted estimated future expenditures required for completion and less profit allocated to inconpletod activities. The effect of the use of net realizable value is that increments in value for all reasons are rocognized in the period in which they occur. The results are similar to those obtalned under the variations of current cost which recoznize production income.

Net realizable value is a very usoful concept when it can be determined with a reasonable degrae of accuracy. Unfortunately, net realizable value cannot be measured with the desired degree of accuracy in many cases. Furthermoro, tho not realizable value concept is not applicable to all assets, e.g., flxod assets and some intangible assots. Net realizable value is much less objective than historical cost and somewhat less objectivo than current cost. 
CHAPTER VI

\section{DISCOUNTED CASH FLOW}

\section{Introduction}

The past three chapters have been discussions of three altornative measuronont methods. This chapter Is a cilscussion of a fourth alternatire-miscounted cash rlow. At the prosant time, it is unlikely that the discounted cash flow measuremont basis will bo adoptod for general use. Although it is perhaps the most idoal method, it is the most difricult to apply. Assets may be thought of as service potentials. The value of an assot may be expressed as tho value of its service potential; an asset may be moasured by moasuring its servico potentials. Tho disoounted cash flow concept (sometimes called the discounted future receipts concept or discounted services concept) is designed to measure the sorvice potentials of alther indiviciual assets or assets as a group.

Not roalizable value is a similar conoept and could be used to mean tho same thing. As used in this study. not realizable value refers to assots such as inventories which are expected to bo sold. Net realizable value is applicable to very raw assets as was 
discussed in chapter V. The discounted cash rlow concept would apply to all assets.

Discounted cash flow may be referred to as

"not present value or expected future cash flows" and "net present value of expected future cash rlows with adjustments for risk" (11. pp. 505-06). "Discounted" means reduced by some rate of interest becauso of the time ractor. The concept refers to a net valuation-reduced by ruture expeaditures also discounted back to the present.

Al though the concopt might be applied to certain Individual assets, it is probably more appropriately applied to the enterprise as a whole. Individual assets may have servico potential only when used along with other assets in an enterprise, or they may have greater service potential when used with other assets. Average service potontial of a given asset to an average enterprise is possible, but it may have littlo significance for a given enterprise. Discounted cash flow usually measures the earning capacity of a given enterprise.

Reed K. Storey, in an artiole entitled "Cash Movements and Periodic Income Determination" presents six statements concerning the nature of periodic income and its determination which are particularly relovant to the discounted cash flow concept. Mr. Storey draws upon an article by kidward G. Nelson. "The Relation 
Between the Balance Shoet and the Proflt-and-loss

Statement." which appears on pages $132-41$ or the

Aprt3, 1.942. The Accounting Review. The six state-

ments are listed here:

3. (ver the life of a business, revenue is equal to the cash recelpts from operations, and expense is eqqusl. to the cash disbursements from operations; tho profit (positive or negative) is therefore equal. to the difference between cash recelpts and cash disbursements resulting from operations.

2. For any period lass than the life of the enterprise, revenue is equal to the cash that will. be received (pest, present, or future) as a result of the operations of the period, and expense is equal to the cash that will be disbursed (past, present, or future) as a result of the operations of the period.

3. Periodic income determination is essentially a process of asset valuation because the value placed on not nssets at the bepinning and end of an accounting period determines the profit allocated to thet period, or conversely the part of the total proit allooated to periods determines the value of the assets.

14. The rate of profit (whether it is assumed to be equal in all periods or not) is a rate of crowth of eapital value because it measures the proportion by which a given asset or group of assets increases in value during the period due to operations.

5. The value of an asset determined by the invested capital method (adding outlays and allocated profit) equals its value determined by the prosent value of net revenues method (discounting net rovenues by the same profit-rates used in allocating profits under the invested capital method).

6. Income and asset valuation depend on the expeoted amount and tims distribution of cash movements which take place primarily in tho future and are thorefore subjectivo in nature (67. p. 452$).$

This step-by-step developinent is an ald in understanding the nature of discounted cash rlows. 


\section{Economic Concept}

There are many different economic theories or income. One cannot accurately speak of "the" economic theory of income, but one oan zeneralize and speak of an economic theory of income which is perhaps more prevalent than other theories. J. R. Hicks is usually given credit for putting into words the concept of income as the amount that can be spent during a period of time and yet leave the entity as well off at the end of the period as it was at the beginning of the period :

The purpose of income calculations in practical affairs is to give people an indication of the amount which they can consume without impoverishing theinselves. Following out this tiea. it would seom that we ought to derine a man's income as the maximua value which he can consumo during a woek, and still expect to be as well off at the end of tho wook as ho ras at tho beginning (77, 3. 172).

$$
\text { For pirposas of this study, discountod oash }
$$

flow is equated to economio incoma.

\section{Subjectivity}

Discounted cash flow appears too difficult to measure and too subjective to be used in the valuation or all assets. Arthur L. Thomas says the disoounted service approach "cannot, even in theory, Bive a precise value to inclividual assets. It may, though, bo able to five a fairly precise value to companies as a whole, or to entire economies" (78, p. 68). The value of this concept in accounting may be in the valuation 
of entire enterprises. For example, this conoept might be userul in buying or selling an entire enterprise.

With current methods of prediction and measurement. It seems that the discounted cash flow concept is not a likely candiclate for a measurement base. Perhaps new techniques in the future will make the concept more applicable.

\section{Comparison with other Measurement Bases}

The three ineasurement bases already discussed are now compared with the discounted cash flow conoept. This is not to discorer the best base; it is to compare each base with a measurement of economic income.

\section{Historical Cost}

The curront use of tho historical cost concept in rocognizing revenue would have the sane results as this econoulc theory only in isolated oircumstances. For example, the two ooncepts could result in the same amount of revenue if there aro no price-lovel changes during the poriod and thare are comparable inventories at the beginning and end of the period.

The use of the historieal cost concept is not intended to measure rovenue from an oconomic point of view. The accountant is not nocessarily interested in the sane measure of revenue in which the economist is interested. Hoth the eoonomic concept and the accounting concept involve inorements in value. The 
main difference is in the timing of the recognition of such increments. There aro also soino differences in emphasis.

For example, the accountant is usually interested in the income of specific ontities while the economist usually is not. "This specific interest of the accountant makes him more conservative than the economist faced with the same problem--for example, the accountant typically hesitates to recognize a favorable change 'too early' because it may never bo 'realized,' and the party to whom the benefit rlows may prematurely demand his share or act on the presumption that it is his" (31, p. 12).

\section{Current cost}

The economic concept includes in incorso

increases in wolth over time. Such increases in value are inclucied in income thether they are converted into a 1 iquid forn or not.

The currently used realization concept is further from this economic concopt than tho current cost concepts. A sale or delivery is the usual criterion for recognizing revenue at present. Increases in value, especially those increases in value duo to the production of Eoods, are not recognized under the realization concept until the sale or celivery takes place. This could be rar removed in time from the 
actual increast in valus. This incroass in value rafors to both value increments due to production and holding gains and losses.

Tha current oost conoapts are more similar to the eoonoric concept than is the realization concept. The first group of ourrent onst ancepts femphastzing holding gains and losses) comes closer to the economic concept than the realization concept but not as close as the second grouv of onnoapts (emphasizing production income). The segond group of concepts might have practically the same results as the economic concept. Differences between tho coneepts would be due to difrerencos fin the way they are implemented.

\section{Net Realizable Value}

The economic concept described in the preceding paragraphs is similar to the net realizable value concept. Tho diffarance is in the assets to which the concepts apply. Not realizable value is bost applied to oertain current assets. The economic concept, expressed here as disoounted cash flow, applies to the valuation of all assets and therefore to the increase in value, income.

\section{Surtma ry}

The three major measuremont basas in accounting for financial dato are historical cost, current cost, and net realizable value. A fourth base, which is not 
likely to be aoceptable for use in aooounting in the foreserable future, is discounted cash flow. This is intended to be an expression of the economic concept for asset valuation and incone moasurement.

Discounted cash flow is most applicable to asset groups such as an ontire enterprise. This oconomic concept cannot be applied with the same degree or objectivity as the other measurement bases suggested in the preceding chapters. If discounted cash flow could be implomented. it would be the ideal measurement nethod. 


\section{CHAPTER VII}

\section{SUMMARY AND CONCLUSIONS}

Accounting is the measuring of rinancial data. Financial data is measured in order to meet the neods of management as wo11 as persons and entities outside tho accounting entity--external users. These external users include investors, creditors, social control agencies, labor unions, employees, consumers, and the genoral public.

Managemont uses the information provided by systems of accounting to aid in inaking decisions in three areas: planning, controlling, and evaluating. Accounting also serves to make management aware of the need for decisions; this is essential in order for the "management by exception rule" to apply. These three areas of managerial interest imply that management is interostod in what has happened in tho past (evaluation). what is happening at the present (control), as woll as what is expected to happen in the ruture (planning). Accounting serves management's neods in all three areas; accounting is not oonfined to recording the past. isvaluation of past events is largely to ald in controlling and planning. 
The primary accounting statements consisting of the balance sheet, the income statement, and the capital statement are used by management, but management's needs extend beyond these statements. Management needs much more detalled information than is ordinarily provided in these primary statements. Also, management requires information much more frequently than is provided by these primary statements. Management may use these primary statements as a starting point in reviewing the results of financial afrairs. From the primary statements they may go to other accounting records and statements for more details on specific points and for more frequent information.

The external users as a group have diversified interest in the measurement of financial data of an entity. The published financial statements are the main source of information to these users, although some users obtain additional information. Creditors may receive information according to the contract between the entity and the creditor as well as additional information concerning collateral and earning power. Potential creditors may also ask for information more detailed than that appearing on the financial statements. Governmental agencies have the authority to require specific types of information. These are typical examples of external users receiving information in addition to that presented in the financial statements. 
Investors and prospective investors compose the largest group of users of accounting statements. Investors are interested in some combination of dividends, appreciation, risk, and diversity. It is not known exactly how investors use accounting statements and to what extent rinancial statements afrect their decisions. It is assumed that investors use accounting statements to determine financial position and results of operations.

Internal users (management) and external users have different noeds. Although high levels of management inay use the primary accounting statements as a starting point, they desire much more detalled and more rrequentiy provided information on specific items. At lower levels of management even more detatl and more rrequently provided data are destrable. The lover levels of management may have no need for the primary accounting statements.

External users, faced with decisions which differ froin management's declsions, need essentially different information. These external users are more interested in results of management's efrorts than in the detailed information needed for managerial decisions in various areas of an organization. External users, especially creditors, desire a report on management. They are more interested in plans for the ruture than in the process of managerial planning. The 
published rinancial stateinents are intended to moet the needs of most external users while they serve the noeds of manageinent to only a small extent.

Although the typo and dotall or Sinanoial data desired by external and internal users aro not tho same, both groups of users are interested in an appropriate measurement of flliarial data. The purpose of this psper is to analyze and corapare the most prominent of the laeasurouent mothods which tave been suggostod In the accounting 11 terature. The moasurenent methods, or bases, chosen for inclusion are historical cost. current cost, net roalizable value, and discounted cash flow.

Accounting has always been a system of measurIng financial data. The ldea that measurement theory applies to accounting is not new, but recent yoars have witnessed an inoreased emphasis on the application of measuremont thoory in accounting.

Measurment may be defined as the asshegnent of nurateis to represont properties of objacts or events according to rule. Measurament is sometimes deringd more bruadly to include the assignuent of numerals to objects or events themselves. This broader defiulion includes raere classification within the sphere of measurement.

A one-to-one relationship must exist between the quantities of the propertios or the objects and the 
number sjstion used in masurement. The number systera should possoss orclered numbers, orderod differences be lwhon numbur:, and a unlque origin. A scal of measursuont i.s = stablished whon numbers are assigned to objects or propertices of objects in such a way that the relations betwaen the numbers indicate relations botween the objects or properties of the objects.

Accorling to Sterons the lowest scale, callad the nominal scalo, involves mere classification and does not necessarily involve order, distance, or origin. Vany experts would not consiler this as a scale at all. The orjinal scale, the next soale, implies order and includes the reatures of the nominal scale. The next scale, the interval scale, has the features of the ordinal scale with an added reature of a meaningrul size of the distance betwoen pairs of numbers. An interval scale with a natural origin is called a ratio scalo. the hi shest type of scale. bach scalc after the first grows out of the prececing scalc. The applioation of each scale is restricted to a more specific area than the preceding one.

There are threo kinds of moasurement. (They have no relationship with the types of scale.) These are fundainental measurement (which has meaning through natural laws ralating various quantitios of the construct to each other), derived measurement (whioh has meaning throu laws relating the property to other properties). 
and fiat measurement (whioh has meaning by arbitrary definition).

Measurement theory is essential to accounting because the purpose of aocounting is to measure. Heasurement is concerned with the quantitative aspects of objects. Accounting is also concornod with quantification. Perhaps accounting should also be concerned with nonquantitative aspeots of objects, and perhaps in the future this will be a significant feature of acoounting. This paper discusses accounting from a quantitative aspect only. Accounting is sometimes defined even more narrowly to include quantitative measurement in financial terms only.

In order for measurement in accounting to take place, several decisions must be made. The objectives of the entity is the rirst ractor to determine. The profit motive is usualiy assumed to be the primary motive of business entities. Other objectives do exist, but they are usually subgoals.

Before measurement may take place, the types of factors which may serve to attain the objectives or objectives must be determined. The selling of produets and the rendering of services are usually considered to be the means of obtaining the objectives. Accounting attempts to measure oniy the financial and some other quantitative aspects of the selling of products and rendering of services. 
Accounting cannot usually moasure incoas directly.

The forinulation of rules has been found nocessary in order to dotarine "accounting income." Income as doteruined by the application of accounting rules may be considored a surrogata, or substitute, ror ral 11100:as.

A theasuring nethod and a measuring anit must bo solocted before income and the subgoals nay be measured. This is the basic measurement task of accounting. The choice of a measurement method is the central theme of this paper. The measurement unit is the language or the measurement method. Accounting expresses financial data in monetary terms, but this involves the problem of the changing purchasing poser of the dollar. Are measurements to be made in terms of dollars with no recofinition made of the changed purchasing power betweon two points in time?

Arter these decislons concerning objectives and methods have been made, the measurement process itself may take place. Analysis of the results and the use of measurement follows the measurement process. The measurement methods and units should be deterinined in 1 ight of the use expected to be mado of the results. Since the primary goal of a business enterprise is to make a profit, acoounting should not oniy measure the attainment of the goal but should actually make a contribution toward reaching that goal. 
The goal of accaunting should be to noasuro value. The rules applied in accounting arrive at a substitute for value and increases in value. Substitutes and estimates fail to messuro actual valuo, so amounts refleoted in finanoial statements may imply nccuracy which does not exlst. Coipleto accuracy is usually unnocessary, the degree of accuracy depending upon the purpose for which the measurement is being made.

The user of accounting data should be made aware of the degree of accuracy reflocted in the data. Perhaps financial statements should indicate the probability and degree of error inheront in measurament methods used and the results of the measurement. Accounting measurement utilizes all four types of scales of measurement. The classification used in the chart of accounts is an example of the notainal scalo. Ordinal soales are used in statement analysis. The time dimension is an examplo of the uso of the interval scale. The use of dollars is an example of the ratio scale. The kind of measurement used in accounting is usually fiat. Most measurement mothods such as historIcal cost and ourrent cost are examples of measurement by fiat. Net roalizable values and disoounted cash flows approach fundamental measurements. Four criteria are chosen to be used in discussing and comparing these four measurement mothods. These critoria aro relevance (userulness), objeotivity (veririability and freedom rrom bias). feasibility, and quantiriability. 
The fixst measurement metiud is historical cost (Chapter III) which is tenerally accepted for use in accounting statenats. Historical cost (sometimes called original cost and transactiun pricol is an objectivo basis rox that which is cxchanged. The use of this meas urenent metinod in the accounting recurds implies that accounting is the allucalion of historical cusls end revenues to the riscal porious.

There are several conceplis so clusely relatod to historical cost that they are almost insoparablo. one of these is the going concerin cuncopt. Dusillass enterprises are assuned to have a continuous Iire, and the accounting records are based on this assumption. This means that 1iquidation value uay be of little value, and this is ofton intorpreted as support for the historical cost cuncept. An interpretation wich is loss acceptable in current practico is that net realizable values and discounted cash rlows would be a naturel consequence of the going ouncern concept.

Another conoejt related to the historical cost concept is the time period conoept. The uso of the timo period makes it necessary to doteruine incoino and assot neasurements boiore the enterixize life is over. Hules raugt be made to estimate the rosults of oporations. Healization is tho cusicopt usod to dotoriaino what revenue is to be racognizoul dusing a bivan tire period. The dueinant intorprotation of the realization 
concept is that a change in value hes taken rlaco rith suffiolant objectivity to warrant recognition in tho accounts. A sale is usually thought of as having sufriclent objectivity and is generally the mecopted critaston for realization. Assets remain on the bosles at historical cost until realination is deensd to have takan place.

Tho reiatod soncayt of matching is usod to determine what oxponses should bo leducted from the racognized revonue. Those costs which were necessary to attain the revonue of the porioc? should be matchod With tho revanuo.

Ariother concept directly raleted to the historical cost conoopt is objoctivity. Objectivity imnlios vorifiability and rroedom from bias. Objectivity is one of the most important advantages of historical cost.

The conservatism concept is also related to historical cost. Hstorical cost is the most conservative cuncopt of those disoussed hore.

Ci the conoepts discussed here, the ne nost closely related to historical oost is the realization concept. Suggestions have bean nade to use a rore liberal realization conoept than is currontly accepted. Given in current practice thers are sovgral exoeztions to the peneral rule that a salo is raguirod for roallzation. In sopo situations such as sbipbuiling realization may occur Jusing production. Completed produotion 
is required in some situations such as inining of metals and producing agricultural products.

The use of historical cost along with the closely related realization concept results in some shortcomings in the financial statoments. A reader is $11 k e 1 y$ to be mislead if he assumes that financial statements reflect values. In order not to be mislead, the reader must realize what measurement method is used and the implications of its use.

Under the historical cost concept, capital gains and losses are not recorded as they arise. Also, when capital assets are consumed, capital gains and losses become part of normal profit. Another major limitation implicit in the use of historical cost is the failure to recognize changes in value as production takes place and as services are rendered.

The use of historical cost may make difficult the comparing of the accounting statements or a particular entity over a period of time. One reason for lack of comparability is the use of alternative methods which are permissible with the historical cost measurement method. Another major reason for 1 ack of coinparability is price-level change. General and speoirio price levels do change from period to period and thus distort the rinanolal pioture based on historical cost. The use of historical cost also results in laok of uniformity between enterprises. The problems of alternative methods and price levels are again involved. 


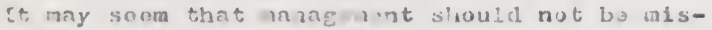

Iead by financiai. Stationnts protucej undor tize hijtorical oost conewpt whon they havo ace.ss to mor inforeation if destrof. Wanages may not und rest ind acosuntin. well enou;h to know what cones,ts lnd ril tid priparation of accounting statoments ayd bise inherent linitatlons of the statements. Sren if menzzers do understand accountin?, thoy must raice th: ir gin adjustmonts to finanetal statemonts and thorefor theg ruily liak the information they necr.

Investors and prospective investors also need relevent information in the financial statements ais they must fignerally rely on such statements ovon wore than management. Thore are three $\mathbf{r}$ sasous why investors may not rely on published finaricial statements. First, the statcments may not Bive adegunte information to form the basis for a decision. The statements may be intentionally biased in addition to shortomings al ready mentioned. Another criticism of published financial statements is that they provide investors with very little information concerning the ruture. The seoond possibility as to why investors and prospective investors do not use published rinancial statements in making decisions is that other sources or information may be more helprul. Secondary sources such as investment brokers, financial periodicals and news reports, and investment manazers for 
institutional inv stors may be used. 'Jther sources include hot tips, divilenrl records, ond daily stockmarket activities. The use or these sourcos does not necossarily $1 m_{\text {bly }}$ a lack or usefulness of financial statements. They way provide a dirfersnt type or information and meet difrerent objectives.

The third possibility as to why investors and prospective invostors do not use pubilished financial statements in making decisions is that they mey not possess surficient knowledge of accounting. A possible solution would ba to prepare statements in such a way that they could be understood and used by those who have some inowielze of rinancial data but who are not exports in accounting.

Users of financial statements other than managemont and investors generally have 1 ass need for the statements because they may use other sources of information. However. they nay be misleal if they rely entirely on the published rinancial statcments.

An alternative to the historical cost measurement nethod is current cost (Chapter IV) which is a term chosen to include many variations of narket value and replacament cost. Variations of current cost seem to rall into one of two types: those which separato holding sains and losses frora operating incoine and those which recognize income on a production basis. The socond type might also distinguish holding gains and losses from other income. 
Incorae as usol in this study neass both unoxpected s.ncrements in valuo (umbe profte) and incsements ciue to above-averege decision-making ability and risk tuking. Aocounting incour also includes interest on capital. fnerements in value for any of these foasons way bo considered income whothur recognized or not.

Incowe is not necesserily rocognized wimen increments in valuo tako place, but doternination of wou increments take plece is helprul in deciding when to recognize revenue. The business process includes purchasing, prodiction, holding, and seiling, each of which may give rise to ralue incroment3. Alternatives to the historical cost measurement method suggest the recognition of some of these increments as they take place.

Current cost consopts are intended to reasure changes in the specific prices as contrasted with general prica-1evel changos. IIt is assumed that appropriate adjustments will be racio for chanses in the comeral price lavol as well.) The increasent ineasured deponds upon the particular current cost concepl used. sdwards ani Eoli recominend tuo curzant cust conceptse-realizable profit and bustuess profit. Realizable proflt is couposed of realizabie operating profit and realizabla capital gains. Nealizablo uperating prorit is the increaso in opportunity cost due to production and is thus tho inorement in yaluo duo to production. (Production here implies all buginess activities 
other thas husdilg.) Joabizablo capital fains are tho gains lue to the incrasse ln opportunity cost uver time and linus tho incroment in valuo duo to holding. slwards and Bali's businoss proflt concopt is composod of curront oparating propit and roalizabio cost savings. Curront operating profit is tho difference between current cost beforo projuction and curront valuo aster production. fiurreat cost is tho cost of acquiring inputs at the prasant tino, and curront value is the value actuaily realizod for goods or servicos sold.) Reallzable cost javings is the incroase in current cust over time. Thls concept results in the recuguition of increnents in value due to holding wile tho rowalning increments are not recognized until tile tiue of sale. ¿dwards and Beil would choose business prorit as bolng tho more userul of tho tivo comcepts.

sprouse and Hoonitz suggest a current oost ooncept which they cali replacement cost. Although they do not make it choar how repiacenont cost should be deterinined, they seom to be suggesting the use of what Bdwards and bel1 call curront cost. This iuplies that holding giains and losses would bo recognizod as lncurred but that che recognition of other incrubents in value would be postpuned until the time of sale. other current cost concepts fall linto one of the two categories. Ine accrotion concept is an axamplo of those which emphasize production incous white 
Horngren's concept (see page 108) is an example of those concepts which emphasize holding gaing and losses.

The separation of increments in value jus to holding activitios from other businass activitios is a good starting point in analyoing poratin? results. Although it may not always be possible to dotermins the cause of holding gains and lossas, they are at least assigned to the period in which they arose and are not included with other income.

Current cost concepts emphasiming holding gains and losses have the advantape of bein? closer to current practice than the other type of concepts. The current. cast of inputs can be determined without much cost and difriculty (reasibility) and objectively deterained.

Current cost concepts which emphasize production income are recommended less of ten than concepts emphasizing holding gains and losses. Concapts emphastzing production income are more theoretically desirable because they approximate value more closely. Also, this concept may be used to deternine both production incomo and holding gains and losses. but the difficulty end expense may make this method less practical than the other type of concepts.

Historical cost and current cost have boen compared on the basis of userulness, objoctivity, and feasibility. To the ortent that econouic value is an accurate indicator of financial nosition and incore, 
then current cost is more useful (relevant) than historic cost. The nccessity of changing rroin the use of historic cost to current cost in the financial statements would somewhat limit the userulness of the statements until readers bocame accustomed to the new measurement method. Complications in the accountin; statements in order to rerlect current cost rather than historical cost would perhaps of set to some extent the increased usefulness of current cost. One userul aspect of current cost concepts which recognize production incoine is that the direct costin; controversy would be eliminated. The other current cost concopt would have no efreot on the controversy.

Usefulness and objectivity are not necessarily in conflict as objectivity may contribute to userulness. The more significance the reader can attach to financial statements, the more usoful they may become to him, and objectivity may make tho staternents more significant.

Historical cost is derinitely more objective than current cost, but does ourrent cost have surficient objectivity? In many cases curront cost does have sufficient objectivity. When current cost can be detorinined with surficient objectivity to bo included in the financial statemonts then lts use soems to be feasible. 
Although there are several variations of net realizable value (Chapter $V$ ), the concept generally implies recognition of value increases or deoreases as they occur. One variation is expected revenue less expected costs of oompletion and disposal. All profit is attributable to the buying or produoing activity. and no profit is attributable to the other actirities. Another variation is identical to that suggested in the preceding paragraph except for a reduction by a nornal income on activities not performed. $\$ t 111$ another variation postpones al1 operating incose until the time of sale. These variations may or may not use a rate of discount to compute the present value of ruture revenues and expenses.

The most logical variation of net realizable value seers to be discounted estinated sales price less discounted estimated future expenditures required for completion and less profit allocated to incompleted activities. This variation would assign value increments to the activities performed. The determination of holding gains and losses from other income is possible, but it is not usually built into this measuroment method. The net realizable value concept seems to apply to only inventories, accounts receivable, and other current assets.

The net realizable value oncept is compared with historical cost on the basis of objectivity. 
usefulnoss, and foasibility. Iistorical cost is equoraliy more objoctive than not realizablo valuo. Vet raalizablo valuo has an advantaga over historical cost bocause it is a closer approrimation to value. Net realizablo value is sugrested as a moro useful measuremont comoopt than historioal cost when historical cost doos not closely rasambio valuo and net realizabls value can bo doterained with only a snall jrobable degree of error. If net realizable value can be determined with a high degreo of accuraoy and withont great cost, then the use of the coneept would be reasible. Net realizable value is comparad with current cost on the basis of the same criteria. The current cost concepts which emphasize holding gains and losses are fenerally nore objective than net realizable value. Not realizable value is inore useful in that it is a closer approxination of value, but current cost is useful because it separates holding gains and losses from other income. Current cost is usually wuch easier to determine than not realizable value and thereforo is more roasible.

The use of the net realizable value concept givas substantially the sane results as tho use of a current cost cuncopt which rocognizos income on a production basis. Cornparison of the two concepts on the basis of userulness, objectivity, and foasibility is of little value. 
Disconnted cash flow (Chaptor VI) is th? fourth and last measurement mathol discussed. This conopt may be applied to inlividual assets or jompo of assets. Its applisation to zroups of assets ls moro practical as it is difficult to break down an enterorise's cash flow between the varions assots. This flow conoept is similar to not roallanble value except that it applies to a 11 assets.

Discountod cash flow is a goot mosuro of econoinic income and can therefore ba constclered the ideal measurement method. If discounted cash flows could bo determined for an enterprlso then it would be the most userul imeasurement method. Howev r, discounted cash flows appear too difficult to measure and too subjective to he used in the valuation of al1 asset.s.

af the four moasurement mothods discussed, discounted cash flows is the ideal measuro of economic value. Net realizahlo valuo is the sane thing but applies to only a linited number of assets. The current cost concept whlch measures production income comes closer to being jideal than the other current cost concept. The curront cost concept which emphasizes holding trans and losses ranks next, and historical cost ranks last. 
1. Davidson, Sidney; Green, David, Jr.: Jorngren, Charles T.; and Sorter, Geore H. (ed.). An Income Approach to Accounting Theory. inglewood Cliffs: Prentice-lall. Inc.. 1964.

2. Sprouse, Robert T., and Moonitz, Maurice. A Tentative Set of Broad Accounting Principles for Business lintorprise. New York: American Institute of Certified Public Accountants, 1962.

3. Study Group on Business Income. Changing Concepts of Business Income. New York: The Macmillan Co.. 1952.

4. Moonitz, Maurice. "Should We Discard the Income Concept?" The Accountine Review. Vol. 37. No. 2 (Apri1. 1962). pp. 175-80.

5. Bedford, Norton M. "Discussion Comments," Research in Accounting Measurement. lidited by Robert K. Jaedicke, Yuji Ijiri, and Oswald Nielsen. American Accounting Association, 1966.

6. Stevens, S. S. "Measurement, Psychophysics, and Utility," Measurement, Definitions and Theorios. adited by c. liest Churchman and fhilburn Ratoosh. New York: John Wiley \& Sons. Inc.. 1959.

7. Russe11. B. Principles of Mathematics, Second Fidition. New York: Norton. 1939.

8. Torgerson, Warxen S. Theory and Methods of Scaling. New York: John Wiley \& Sons. Inc.. 1962.

9. Campbe11. N. R. "Symposium: Measurement and Its inportance for Ihilosophy." Proe. Arist. Soc. Suppl. London: Harrison, 1938.

10. Mattessich, Richard. Accounting and Analytical Me thods. Homewood, Tliinois: Richard D. Irwin. Inc.. 1964.

11. Bierman, Harold. Jr. "Measureinent and Accounting." The Accounting Review, Vol. 38, No. 3 (Ju1y, 1963). PP. 501-7. 
12. Jaedioke, Robert K., Ijiri, Yuji, and Nielsen, Oswald. (ed.). Research in Accounting Measurement. American Acoounting Association, 1966.

13. Churchi11, Neil C.. and Stedry. Andrew C. "Some Developinents in Management Science and Information Systems with lespect to Measurement in Accounting." Research in Accounting Measurement. Edited by Robert K. Jaedicke. Yuji Ijiri, and Oswald Nielsen. American Accounting Assoctation, 1966.

14. Kircher. Paul. "Measurements and Managerial Decisions," Measurements: Definitions and Theories. Bdited by C. West Churchman and Filburn Ratoosh. New York: John wiloy \& Sons, Inc.. 1959.

15. Anthony. Robert $N$. "Synthosis: Research in Accounting Measurement," Research in Accountins Measurement. idited by RobertK. Jaedicke. Yujl Ijiri, and oswald Vielsen. American Acoounting Association, 1966.

16. Gordon, Myron J., Horwitz, Bertrand N., and Meyers, Philip T." "Accounting Measureinents and Normal Growth of the Firm," Research in Accounting Measurement. Editod by Robert K. Jaedicke, Yuji Ijiri. and Oswald Nielsen. American Accounting Association, 1966.

17. Devine, Carl Thomas. "Some Conceptual Problems in Accounting Measurements," Research in Accounting Measurement. idited by Robert K. Jaedicke, Yujl Ijirl, and Oswald Nielsen. American Accounting Association, 1966.

18. Ijiri, Yuj1. "Physical Measures and MultiDimensional Accounting." Research in Accounting Measurement. isdited by Robert K. Jaedicke, Yuji Ijiri, and Oswald Nielsen. American Accounting Association, 1966.

19. Johnson, Charles is. "Management's Role in Bxternal Accounting Measurements." Research in Accountine. Measurement. sdited by Robert K. Jaedicke, Yuji Ijiri. and Oswald Nielsen. American Accounting Association, 1966. 
20. Ijixi, Yuji: Jaedick:e, Roburt K.: and Knight. Kenneth is. "The kffects of Accounting Aiternatives on Managemont Decisions," Research in Accounting Measurement. idited by Robert K. Jaedicko, Yuji Ijiri, and Uswalc Nielsen. American Accounting Assuciation, 1966.

21. Churchnan, C. West. "Why Measuro?" Measurements; Derinitions and Theories. jditad by C. West Churchuan and Thilburri katoosh. New York: John Wiley \& Sons. Inc.. 1959.

22. Sprouse, Robert $T$. "The Measurement of Financial Position and Incomo: Purpose and Procodure." Resaarch in Accounting Measuremant. Jifitá by hobert K. Jaedicke. $\overline{Y u j i} I j i r i$, and Uswald Nielsen. American Accounting Association, 1966.

23. Ijiri, ruji, and Jaadicke, Robert h. "kollability and bbjectivity or Accounting Measuretwants," The Accounting Heview. Vo1. 41. No. $3(\mathrm{Ju1y}, 1966), \mathrm{pN}, 474-63$.

24. Chambers. 1i. J. "Measurement in Accounting." Journal of Accounting Research, Vol. 3.. No. 1 (Spring. 1965). pl. 32-62.

25. American Accounting Association Comitted to Hrepare a Statement of Basic Acounting Theory. A statement of Basic Accounting Theory. Anerican Accounting Assuciation, 1966 .

26. Haxvarc Business School Aocounting Round Table. The Messuroment of Iroperty. Plant, and irguijment in Vinancial statements. Boston: Hurverul University, 1964.

27. American Accounting Assoolation. Accounting and Reporting Standards for Corporate Financial Stacements and procoulng Statononts and Supplements, 1957 Revision. Columbus. dhio: tuneriomn Aocounting Association. 1957.

28. Kamph, Harry N. " Uurreni Values--An Imperative in Today's Financial Reporting." N. A. A. Bul1etin. Vol. 4\%, Soc. 1 (Aug., 1961). PP. $17-24$. 
29. Hatfield, Henry Rand. Modern Accounting. New York: D. Appleton-Contury Co.. 1909.

30. Storey, heed K. "Revenue Realization, Going Concern and Measurement of Income," The Accounting Review, Vol. 34, No. 2 TApr.. 1959). pp. 232-33.

31. Moonitz. Maurico. The Basic Postulates of Accounting. New York: American Institute of Certified fublic Acoountants, 1961.

32. Edwards, idgar 0.., and Bel1, Hilip W. The Theory and Measurement of Business Income. Berkoley and Los Angeles: University of California Press, 1961.

33. American Accounting Association 1965 concepts and Standards Research Study Committee--The Matching Concept, "The Matching Concept," The Accounting Review, Vol. 40, No. 2 (Apr.. 1965), pp. 268-72.

34. Arnett, Harold E. "Recognition as a runction of Measurement in the Realization Concept." The Accountinp Roview. Vol. 38. No. 4 Toct.. 1963), PI. 733-41.

35. Arnett, Harold is. "What Does 'Objectivity' Mean to Aocountants?" The Journal of Accountancy. Vo1. 111. No. 5 (May, 1961), pp. 63-68.

36. Windal, Floyd W. "The Accounting Concept of Realization," The Accounting Review, Vol. 36, No. 2 (Ap r., 1961), pp. 249-58.

37. Grady, Paul. Inventory of Generally Acoopted Accounting reinciplos for Business interprises, Accounting Hessarch Study No. 7 . American Institute of Certified Public Accountants, New York: 1965.

33. Haton, W. A, Accounting Theory. New York: The Ronald Press Co.. 1922.

39. American Accounting Association Comatter on Conoopts and Standards--General, 1963. "Roport of the Comnittee on Concepts and Standards--Genera1," The Accounting Review. vol. 39. No. 2 (Apr.. 1964), pp. 425-31. 
40. Winda1. Floyd W. "legal Background for the Accounting Concept of Roalization." The Aceounting Review. Vol. 38, No. 1 (Jan., 1963). p. 35-36.

41. Spilier. Earl A.. Jr. "Kevenue Postulate-Realization or Becognition?" N.A.A. Bulletin. Vol. 43. Sec. 1. No. 6 Feb.. 1962), po. $41-47$.

42. American Accounting Association Comitteo- -1964 Concepts and Standards Research Study Committee--The Realization Concept. "The Realization Concept." The Accounting Rovtaw. Vol. 40, No. 2 (Apr..1955). 10. 312-.22.

43. Sprouse. Robert T. "Observations Concerning the Realization Concept." The Accounting Roview. Vol. 40, No. 3 (July. 1965). pp. $522-26$.

44. Paton. William A., and littleton, A. C. An Introduction to Corvorate Accounting Standards. American Accounting Association. 1.940.

45. Bowers, Russe11. "Tests of Income Realization," The Accounting Review, Vol. 16, No. 2 (June, 1941), pp. 139-55.

46. Blough. Garman C. "Challenfes to the Arcounting Profession in the U. S.." The Journal of Accountancy, Vol. 108, No. 6 (Dec..1959). p. $37-42$.

47. Ross, Howard I. "Crucial Importance of Valuation in Accounting." The Journal of Accountancy. Vo1. 1.13, No. \& Toet.,1964). pp. 68-70.

48. Heilman, F. A. "Realized Incoine," Mhe Accounting Reviev, Vo1. 4, No. 2 (June. 1929), pp. $81-87$.

49. Bruns, Wil1tam J.. Jr. "Inventory Valuation and Management Decisions," The Accounting Review. Vol. 40. No. 2 (April. 1965). PR. 345-57.

50. Dyckman, Thomas $\mathbb{R}$. "On the iffects of BarningsTrend. Size and Inventory Valuation Procellures in bvaluating a Rusiness $11 \mathrm{rm}$, Research in Accountinf Measurement. edited by lobert K. Jaed1cke. Yuji IjIri. and Oswald Nlelsen. Amerioan Aocounting Association, 1966. 
51. Thomas. Arthur L. "Value-itis'--An Impractical Theorist's Rep1y." The Accounting foview, Vo1. 39. No. 3 (Ju1y, 1964), pp. 574-81.

52. Anreder, Steven S. "Hitralls for the Unwary; Corporate Accounting. Investors Have Learned the llard Way Is Full of Them," Barron's. Vo1. 42 (Dec. 24, 1962). p. 3rr.

53. Dinsmore, William H. "Dear Stockholders: trerything Looks Rosy..." Harper's Magazino. Vol. 230. No. 1378 (March, 1965). P. 133fr.

54. Doan, Joel. Manamerial Econonics. Now York: Prentice-lia11. Inc., 1951.

55. Backer. Morton, "Accounting Theory, Ubjectives and Measurements," The Journal or Accountancy, Vol. 116, No. 4 (0et., 1963). P. $57-63$.

56. Dickens, Robert L. and Blackburn, John O. "Iolding Gains on Fixed Assets: An Slement of Business Income?" The Accounting Feview. Vol. 39, No. 2 (Apr., 1964), pp. 312-29.

57. Horngren, Charles T. "Increasing the Utility of Financial Statements," The Journal of Accountancy, Vol. 108, No. 1 (July. 1959). pp. $39-46$.

58. Cannon, Arthur M. "What's Wrong With Financial Reporting? The Investor's View," The Journal of Accountancy. Vo1. 112, No. 2 (Aug., 1961). pp. 32-33.

59. Hendriksen. Eldon S. "Purchasing Power and Replacement Cost Concepts--Are Drey Related?" The Accounting Review, Vol. 38, No. 3 (Ju1y, 1963). pp. 483-91.

60. Sprouse, Robert $T$. "Historical Costs and Current Assets--Traditional and Treacherous," The Accounting Reviow, Vol. 38, No. 4 (Oct.. 1963). pp. 687-95.

61. Fhillips, idward. "The Accretion Concept of Income." The Accounting Review, Vol. 38. No. 1 (Jan.. 1963). PP. 1-25.

62. Horngren, Charles $\mathrm{T}$. "How Should We Interpret the Realization Concept?" The Accountine Review. Vol. 40, No. 2 (Apr.. 1965). pp. 323-33. 
63. Sorter, Coorge H. The Boundiries of the Accounting Iniverse: The Accounting Pules of selection, Unpubitshed th. U. dissertation. University of Chicago, 1963.

64. Vattor. William J. The Fund Theory of Accounting and Its Implications for Inancial Revorts. Chícago: University of Chicago jress, 1947.

65. Mnerican Accounting Association Comitten on Concopts end Standards--Inventory Heasurement. "A Discussion or Various Approaches to Inventory Measurement. Supplementary Statement No. 2," The Acrountinf Rev1eV, Vo1. 39. No. 3 (July, 2964$), \mathrm{PL}_{2}, 700-14$.

66. Whilips. C. Tdward. "The Revolution in Necounting Theory." The Accuntine Review, Vol. 33. ivo. 4 (oct.1963). pp. 695-709.

67. Storey, Reed K. "Cash Movements and Periodic Income Determination." The Accounting Roview. Vol. 35. No. 3 TJuly. 1960). P. T, if.9-54.

68. Chambers, R. J. "Measurement and Objectivity in hocounting." The Aocounting Review, Vol. 39. No. 2 (Apr.. 1964). pp. 264-74.

69. Cireer, Howard C.., and Wilcox, Edward B. "The Case Against rice-level Adjustments in Incomo Deternination," Illinois Certified Fublic Accountant. Vol. 13. No. I (Sopt., 1950), p). 1-14.

70. Fertig, paul is. "Current Values and Index Numbers: The Problem of objectivity." Research in Accountinn Masurenent. Bditad by Robert $K$. Jaedicke. Yuji Tjiri, and Oswald Nielsen. Ainerican Accounting Assoctation, 1966.

71. Paton, Willian A. "Cost and Value in Accountings," The Journal of Acoountancy, Vol. 31. No. 3 (March, 1946). Pp. 192-99.

72. Homburgor, R. II. "Measuroment in Acosounting." Tha Acoountin Heviow, Vol. 36, No. 1 (Jan.. 1951). PP. 94-99.

73. Canning. John B. The Economics of Accountancy. New York: Ronald Pross Co.. 1929.

74. Gilman, Stephen. Aocounting Concepts of Profit. New York: Ronald l'ross Co.. 1939. 
75. May. George O. Iinanclal Accountinf. New York:

The Macmillan Company. 1951.

76. Paton, Wil11am A. "Dererred Income'--a Misnomer," The Journal of Accountancy, Vol. 112. No. 3 (Sept.. 1961). pP. 38-40.

77. Hicks, J. R. Value and Capital. Oxford: Clarendon Press, 1950.

78. Thomas, Arthur L. "Precision and Disoounted Services," The Accounting Review. Vol. 37. No. 1 (Jan.. 1962). pP. 67-72.

\section{Additional Bibliography}

Amerlcan Aocounting Association. "Report of Comittee on Management Accounting," The Accounting Review, Vol. 34, No. 2 (Apr.. 1959). PP. 207-14.

American Institute of Accountants Committee on Auditing 'rooedure. Statement on Auditing Prooedure. New York: American Institute of Certified Iublic Accountants.

Anderson, Corliss D. "What the Analyst Wants In Corporate Reports." Investor Relations: The Company and Its Oroners. Edited by Jerome i. Blood. NNow York: American Management Association, Ino.. 1963). p. $141-56$.

Anderson. Williara T. "Data from Pinancial Statements Are Used in Reaching Decisions," The Journal of Accountancy. Vol. 113. Ho. 5 (May, 1962), P. 89.

Anton, Hector R. "Some Aspects of Measurement and Accounting." Journal of Accounting Research. Vol. 2. No. 1 (Spring. 1964), PL. 1-9.

Bedford. Norton $M$. "The Need for an Extension of the Accrual Concept." The Journal of Accountancy, Vol. 119. No. 5 (May. 1965), Pp. 29-33.

Bevis. Herman W. "Progress and Poverty in Accounting Thought." Tho Journal of Accountancy. Vo1. 122. No. 1 (July, 1966), PP. 34-40. 
Burke, dward $J$. "Objectivity and Accounting." The Accounting Raview. Vol. 39. No. 4 (uct., 1964), pp. 837-49.

Carson, A. B. "Lash Movement: The Heart of Income Measurement," The Accounting Review, Vol. 40, No. 2 (Apri1, 1965), pp. 334-37.

Cook. Frankiin 1. "The Sale as a Test of Income kealization," The Accounting Review, Vo1. 14, No. 4 (Dec.. 1939), Pp. 355-67.

Corbin, Donald A. "Comments on the Accretion Concept of Incoune," The Accounting Review, Vol. 38. No. \& (Oct., 1963). p. 744.

Cruse, Rex B., Jr.. and Summers, Bdward L. "Sconomics. Accounting Practice and Accounting liesearch Study No. 3," The Accounthng Koview, Vol. 40, No. 1 TJan.. 1965). DP. 82-08.

Defliese, Hhilip L. "A Praotitioner's View of the Realization Concept." The Accounting Reviow. Vol. 40. No. 3 (Juity. 1965). Pip. $517-2 \pi$.

Beinzer, Harvoy T. "isplanation Strains in Hinancial Accounting," The Accounting Review, Vol. 41. No. 1 (Jan.. 1966). 1). $21-31$.

Dyckman, Thomas R. "On the Investment Decision," The Accounting Review, Vol. 39, No. 2 (Apr.. 1964), pp. 285-95.

snthoven. Adolf J. H. "bconomio Development and Accountancy." The Sournal of Accountancy. vol. 120, No. 2 (Aug., 1965). pp. 29-35.

bxpoxienoe With Return on Capital to Appraise Managoment Periormance," Aocounting Practice Report Number 14, N. A. A. Bulletin. Vol. 43. No. 6, Sec. 3 TFeb.. 1962).

foss, thilip i. and verrara, Willian L. "The reriod Cost Concept for Inoome Measurement-Can It be Defended?" The Accounting Roview, Vol. 36, No. 4 (oct., 1961), PP. 598-602.

Foulke. Roy A. Eractical rinancial Statement Analysis. Now York: MeGraw-llill Book Co... Inc.. 1961 . 
Fruehlich, Walter. "The Role of Incone Deterin nation in Reinvestment and Investmont." The American Bconomic Roview. Vol. 38. No. 1 (Mar.. 1948). pp. 78-91.

Gibson. James L. "Accounting in the DecisionMaking Process: Some kimpirical bvidence." The Accounting Revlew. Vol. 38. No. 3 (Ju1y, 1963), PP. 492-500.

Heoht, Charles. "Historical vs. Current Cost," The Journal of Accountanoy. Vol. 117. No. 2(5ob.. 1964). P. 30.

Higfins, W. Rodgors. "Valuation of Readily Marketable Inventories." The Journal of Accountancy. Vol. 118, No. 1 (July, 1964). Pp. 25-32.

Hi11. Thomas M., and Gordon, Myron J. Accounting, A Management Approach. Homewood, IIIinols: Kchard D. Irwin. Ino., 1959.

Horngren, Charles T.. and Sorter, George H. Direct' Costing ror External Reporting." The Accounting Review. Vol. 36, No. 1 (Jan.. 1961). pl. 84-93.

Jacobsen, Lyle E. "The Riso of the Profit Deferral Notion--The Concept and Practice of $\mathrm{ppti}_{\mathbf{1}}$ measurement," The Accounting Review. Vol. 38, No. 2 (Apr.. 1963), pp. 235-92.

Kemp. Patrick S. "Accounting Data for Planning, Motivation, and Control," The Accounting Reviow, Voi. 37. No. 1 (Jan.. 1962). pp. 44-50.

Kemp. Patrick S. "Controversies on the Construction of Financial Statements." The Journal of Accountancy. Vol. 38. No. I (Jan... 1963). pip. 126-32.

Knight, Frank H. "Profit," In Encyclopaedia of tho Social Sciences. Edited by idwin $R$. A. Seligman. Now York: The Macmilian Co.. 1953. pp. $430-86$.

Kohler, iric L. "Why Not Rotain Historical Cost?" The Journal of Accountancy. Vol. 116. No. 4 (uct.. 1963). PP. 35-41. 
Lim, Ronald S. "The Mathemetical tropiety of Accounting Measurements and Calculations," The Accountinz Foview, Vol. 11. No. 4 (vet.. 1966). pp. 642-51.

Livingston, J. A.: Miller, Eugene; Stiles, Kenneth: Cannon, Arthur M. "What's wrong with Financial Reporting?" (A Symposium) The

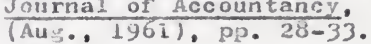

MacNeal, Konneth. Truth in Accounting. Philadelphia: The University of pennsylvania Press, 1939.

Sarple, Raymond P. "Valuo-itis," The Accountino Review, Vol. 38. No. 3 (Ju1y, 1963). PP. $478-82$.

Mauriel1o, Joseph A. "Realization as the Basis for Assat Classification and Measurement." The Accounting Review. Vol. 38, No. 1 (Jan.. 1963). Pp. 26-28.

Mobley, Sybil C. "The Realization Concept: A Useful Device," The Accounting Review. Vo1. 41. No. 2 (Apr., 1966), P. 292-96.

Myers, John H. "The Critical Event and Recognition of Net Profit," The Accountin. Reviow. Vol. 34, No. 4 (uct.. 1959), pp. 528-32.

Ne1son, Edward G. "The Relation Betweon the Balance Sheet and the Prorit-and-Loss Statoment." The Accounting Review. Vo1. 17, No. 2 (Apr., 1)421. PP. 132-41.

"Not to Mislead the Public," Editorial. Tho Journal of Accountancy. Vol. 118, No. 1 (July. 1964). p. 23.

Jal n, Jennie M. "All-Purpose Financial Statements," in Accountant's lencyclopedia. (Prentice-11a11. Inc..1962). p0. 38-80.

Paton. William A. "Premature Revenue Recognition," The Journal of Accountancy, Vol. 96, No. 4 (oct.. 1953). i2P. $432-37$.

Peirson, Graha:a. "Threo Kinds of Adjustmonts for Hrice Changes," The Accountine Review, Vol. 41, No. i (Uct., 1966), pp. 729-36. 
Phll tippe, torald l.. "Top tana; eurnt's stak in Financial Reporting." The Journal of Accountancy. Vol. 13.6, No. G (Doc., 1.963). pi. $37-41$.

Py心, Malcolm L. "Reasons, Probabilities, and Ancounting, Princtples," The Accountin Review, Vol. 35, No. 3 (July, 1960). ग. $+37-43$.

Ray, Delmas 7. Accountin and Business fluctuations. Gainosvilie: University of Florida t'ress, 1950.

Roynolds, Isaac N. "A Vanishing Accounting Item-Replacement Accounting." Me Accountin: Reviow, Vol. 39. No. 2 (April. 1964). PP. $342-46$.

Schmidt, Leo A. "Practical Uses of the Device of Fomal Loglo in Accountants' Jaily Work," the Journal of Accountancy. Vol. 88, No. 5 (Nov., 1949). pp. 373-87.

Seave11. L. Van. "Corporate Annual Reports-Financial Fantasy." Business Horizons. Vo1. 2, No. 3 (5a11. 1959). pp. 92-101.

Solomon, Kenneth [ra. "Current $\nabla$ s. Mistorica] Cost," The Journal or Accountancy. Vol. 117. No. 4 (Apr.. 1964), P. 30.

Sorter, ieor:ze $11 .$, and lornyren, Charles $x$. "Asset Recognition and tconomic Attributes-Tho Rolevant Costing Approach," Iho Account-

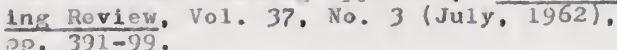

Spacek, Leonard. "Business Success Requires an Understanding of Accounting and Financial. Fiporting." An Income Approsch to Accountin: Theory. Sidited by Sidney Davidson, Dav1d Green, Jr.. Charles T. IJurn; ron, and George H. Sorter. (Enzlewood Clifrs: Prentic - ilall, Inc.. 1964), Pp. 522-38.

Staubus, Corge J. "Dlrect, Rolevant or Absorption Costing?" Tho Accounting Review, Vol. 38, No. 1 (Jan.. 1963), PP. 64-74. 
Storiy, Perl K. "inport for Valuin Invontories at Net jeallzable Value" (ietters). The Jnurnal of Accoentancy. Vol. 118, No.? (AxE.. 1964), Pp. 21-22.

Swoen $y$. Tenry W. Stabilized Accountin. New York: Harper \& Lirother's, 1936.

Thomas, Arthur L. "Iniscounted Sorvicos Arain: The Homogeneity Problom," The Accounting Meview, Vol. 39. No. 1 (Jan.. 1964). pl. 1-1.1.

Vatter, William J. "Does the Rate of Profit Measure Business "friciency?" V. A. A. Buletin. Vol. 40. No. 5 (Jan., 1959). 3. $33-46$.

Vatt $r$, William J. "Income Models, Book Yield. and the Rato of Return," The Accountin:

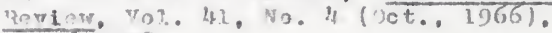
pi. $681-93$.

Vatter. linlliam J. "Urigins of the Fuad Theory," An Incom, 1 peroach to sacount in theory. idited by sidney havidson, David Green, $J_{x}$. Charles $T$. Horn ren, and Goorse H. Sorter. (ingiewood Cliffs: Prenticc-llall, Tac. . 1364).

serntz, wiliam W. "Accountant's Respousibility in Reporting Corporate profits," The Jourial of iccountancy. Vol. 107. No. 3 (March, 1)59). pp. 42-49.

West, Philip L. "Reportins of Larnings to stockholders." Mr. Journai of Accountancy. Vo1. 107, No.2 (Feb.. 1959), pp. 27-32.

Wixon, Rurus, and Cox, Robort G. Principlos of Acoountin. Ver York: The Ronald l'ross

Zerr, Stephen A. "Replacement Cost: Member of the Panily. Wolcone cuset, or Intruder?" Tho Accounting Roview, Vol. 37. No. 4 (ict.. 1962), 3. $611-25$. 
Howard 'roston Sanders was born February 15. 1938. at Colbert, Georgia. In 1955 he was graduated from Comer High School, Comer, Goorgla, and in 1957 from TruettMcConnel1 College, Cleveland, Georgla. In June, 1959, ho received the dogree of Bacholor of Business Administration from the Univorsity of Goorgia. From 1959 until 1962 Mr. Sanders was employod as an accountant by John C.

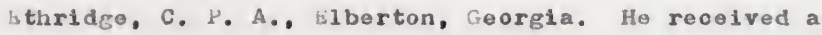
C. P. A. certificate from the state or Georgia in 1961. He enrolled in the Graduate School of the University of Florida in 1962 and recelved the degree of Master of Arts in December, 1963. Ho has pursued his work toward the degree of Doctor of Philosophy sinee that time. Howard Preston Sanders is married to the former Shirley Helen Vandiver and is the rather of two children. Ho is a member of the Ceorgia Society of Certifled Public Accountants, the American Instituto of Certiried Public Accountants, the Arerican Accounting Association, Beta. Alpha Psi. Bota Gamma Sigma, and Mhl Kappa Mhl. 
This dissertation was prepared under the direction of the chairman of the candidate's supervisory committee and has been approved by all members of that committee. It was submitted to the Dean of the College of Business Administration and to the Graduate Council, and was approved as partial fulfillment of the requirements for the degree of Doctor of Philosophy.

August, 1967

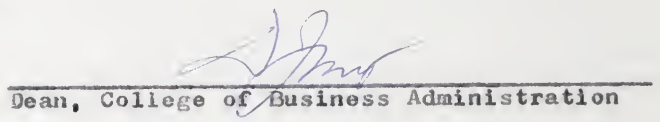

Dean, Graduate School

Supervisory Committee:
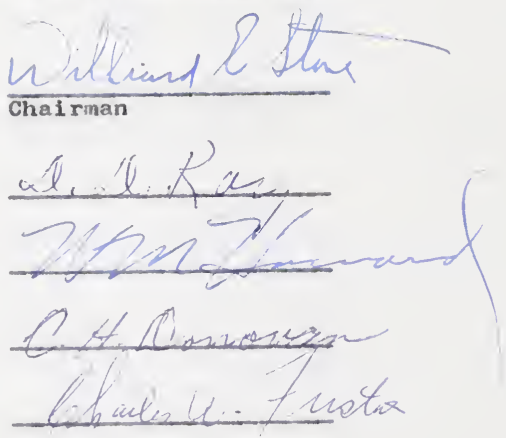